\title{
Modeling of the Sedimentary Interbedded Basalt Stratigraphy for the Idaho National Laboratory Probabilistic Seismic Hazard Analysis
}

Suzette J. Payne

April 2006

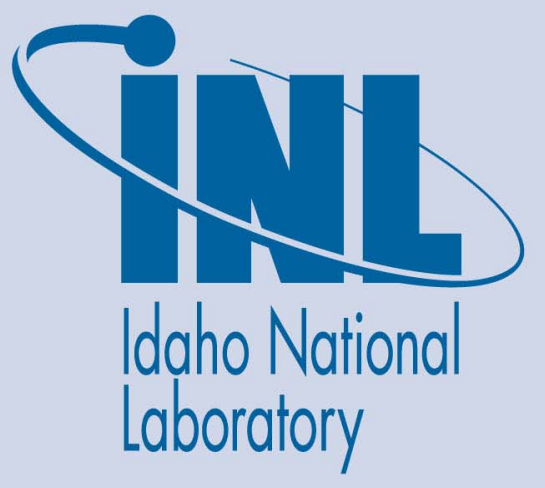

The INL is a U.S. Department of Energy National Laboratory operated by Battelle Energy Alliance 


\title{
Modeling of the Sedimentary Interbedded Basalt Stratigraphy for the Idaho National Laboratory Probabilistic Seismic Hazard Analysis
}

\author{
Suzette J. Payne
}

April 2006

\begin{abstract}
Idaho National Laboratory
Idaho Falls, Idaho 83415
\end{abstract}

Prepared for the

U.S. Department of Energy

Office of Nuclear Energy

Under DOE Idaho Operations Office

Contract DE-AC07-05ID14517 


\section{SUMMARY}

This report summarizes how the effects of the sedimentary interbedded basalt stratigraphy were modeled in the probabilistic seismic hazard analysis (PSHA) of the Idaho National Laboratory (INL). Drill holes indicate the bedrock beneath INL facilities is composed of about $1.1 \mathrm{~km}$ of alternating layers of basalt rock and loosely consolidated sediments. Alternating layers of hard rock and "soft" loose sediments tend to attenuate seismic energy greater than uniform rock due to scattering and damping. The INL PSHA incorporated the effects of the sedimentary interbedded basalt stratigraphy by developing site-specific shear (S) wave velocity profiles. The profiles were used in the PSHA to model the nearsurface site response by developing site-specific stochastic attenuation relationships.

The INL PSHA estimated the probability that ground motion levels will be exceeded at a site for a specified annual frequency or return period. Uncertainties in conceptual models and parameters were incorporated into the hazard analysis through the use of logic trees. The first two branches of the INL PSHA represented the selection of attenuation models that included 1) empirical attenuation relationships from principally the western U. S.; and 2) site-specific attenuation relationships derived from stochastic modeling using parameters specific to crustal properties of the eastern Snake River Plain (ESRP). The empirical attenuation relationships accounted for the uncertainty of estimating ground motions in an extensional tectonic region with limited empirical data. The stochastic modeling accounted for possible attenuation effects of the unique sedimentary interbedded basalt stratigraphy. A weight of 0.4 was assigned to the combined contributions of the empirical attenuation relationships and weight of 0.6 to the site-specific stochastic attenuation relationships. Greater weight was given to the stochastic attenuation relationships because they were site-specific incorporating the unique sedimentary interbedded basalt stratigraphy beneath INL facilities.

Site-specific S-wave velocity profiles were developed for each INL facility area based on observed lithology and measured seismic velocities and densities from several shallow $(<580 \mathrm{~m})$ and four deep drill holes $(580-3000 \mathrm{~m})$. In the stochastic modeling to compute site-specific attenuation relationships, the Swave velocity profiles were used with recordings of regional earthquakes at INL facilities to determine the near-surface attenuation or kappa. At INL facility areas, kappa values ranged from 0.012 to $0.033 \mathrm{sec}$. The kappa values at INL are 
near the low end of typical western U.S. rock values that range from 0.01 to 0.06 sec. The lower kappa values at INL are attributed to the high-velocity basalts that allow more efficient transfer of high-frequency seismic energy through the sitespecific geologic profiles. Comparison of kappa among INL facility areas indicates this effect is offset by the damping due to the low velocity sedimentary interbeds within the basalt stratigraphy at different facility areas.

In 2000, seismic hazard calculations for rock were made for 5\% damped response spectral accelerations at periods from 0.02 to $2.0 \mathrm{sec}$ for INL facility areas: Idaho Nuclear Technology and Engineering Center (INTEC); Reactor Technology Complex (RTC); Power Burst Facility (PBF); Naval Reactor Facility (NRF); Radioactive Waste Management Complex (RWMC); and Test Area North (TAN). The mean hazard and the 5th- through 95th- percentile hazard were computed for the input parameter distributions defined in the hazard model logic trees. TAN has the highest mean hazard because of its proximity to the active Basin and Range faults and regional source zone. PBF has the lowest mean hazard because of its relatively high kappa value of $0.033 \mathrm{sec}$. The mean hazard for INTEC, RTC, NRF, and RWMC are generally similar. The uncertainty about the mean hazard is greater at short periods $(0.02$ and $0.1 \mathrm{sec})$ than at longer periods $(1.0 \mathrm{sec})$ for comparisons of the mean hazard of the stochastic and empirical attenuation models. The hazard estimated from the empirical attenuation relationships exceeds the hazard using the site-specific stochastic attenuation relationships at each facility area. This difference is attributed to the damping effects of the sedimentary interbeds and the relatively low velocity gradient in the basalts compared to a typical western U. S. rock site. These effects were captured in the parameter kappa.

Use of empirical attenuation relationships in the PSHA incorporates uncertainties in source and path effects. The development of site-specific attenuation relationships using a well-validated stochastic numerical ground motion model that incorporates the unique INL geology with its sedimentary interbedded basalt stratigraphy captures the epistemic uncertainties in site properties. These properties include the site-specific S-wave velocity profiles and the near-surface attenuation (kappa). Also, multiple stochastic attenuation relationships were computed using input parameters that have a range of values bounded by site-specific data.

The approach taken for INL PSHA still represents the state-of-the-art and is currently being used at other DOE sites. The methodology used in the INL PSHA is consistent with current DOE Standards and recommendations of the Nuclear Regulatory Commission (such as NUREG/CR-6728). Since 2000 no new data have been collected that would invalidate the ground motion estimates of the INL PSHA, which forms the basis for current rock design basis earthquake (DBE) levels at each INL facility area. 


\section{FOREWORD}

The purpose of the report is to summarize how the effects of the sedimentary intebedded basalt stratigraphy were modeled for several seismic hazard analyses conducted for the Idaho National Laboratory (INL). The modeling of the sedimentary interbedded basalt stratigraphy has evolved through independent peer reviews of the input parameters and results of the INL seismic hazard analyses, which occurred from 1990 through 2001. Two independent panels have reviewed INL seismic hazard analyses. The first panel was commissioned to review seismic hazard analyses conducted in 1990 and 1992 for the New Production Reactor site characterization program. The second review was commissioned by the State of Idaho Oversight office to review the 1996 probabilistic seismic hazard analysis (PSHA) and modeling of the sedimentary interbeds. In 1999, the Nuclear Regulatory Commission (NRC) reviewed the INL PSHA in support of granting a license for the TMI-2 Independent Fuel Storage Installation at the Idaho Nuclear Technology and Engineering Center (INTEC).

This report references the relevant aspects of the past seismic analyses that were incorporated into the most recent computations of the PSHA completed in 2000. The results of the 2000 PSHA support the current design basis earthquake (DBE) levels for rock conditions at INL facility areas that include the: INTEC, Reactor Technology Complex (RTC), Test Area North (TAN), Naval Reactor Facility (NRF), Power Burst Facility (PBF), and Radioactive Waste Management Complex (RWMC).

Past seismic hazard analysis reports contain different names that were used to identify INL facility areas. The current INL facility area names are used in this report and, where appropriate, are indexed to the previous names. These facility areas include: the Material and Fuels Complex (MFC) formerly referred to as Argonne National Laboratory West (ANL); INTEC formerly referred to as the Idaho Chemical Processing Plant (CPP); and RTC formerly referred to as the Test Reactor Area (TRA) or identified as the Advanced Test Reactor (ATR). 
(Intentionally Blank) 


\section{ACKNOWLEDGMENTS}

This report is a summary of work performed by several individuals who along with the author are acknowledged as primary contributors to this report: Ivan Wong (URS Corporation), Robert Youngs (Geomatrix Consultants), Walt Silva (Pacific Engineering and Analysis), and Richard P. Smith (Consultant, formerly with INL). The author thanks Jeff Kimball (U. S. Department of Energy) for his review of this report, and Bill Landman (INL) for his project support. The U. S. Department of Energy, Office of Nuclear Energy, Science, and Technology under DOE Idaho Field Office Contract DE-AC07-05ID14517 funded this work. 
(Intentionally Blank) 


\section{CONTENTS}

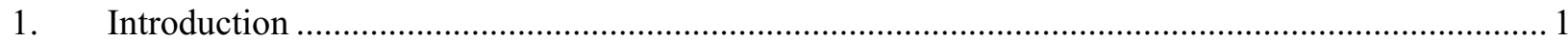

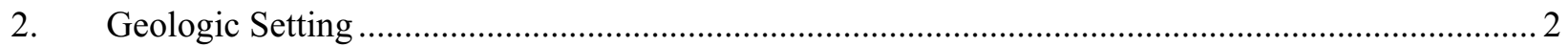

3. INL Probabilistic Seismic Hazard Analysis ............................................................................ 5

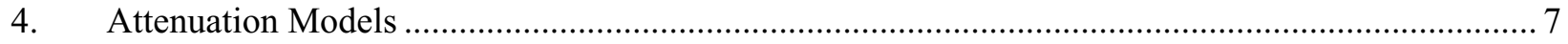

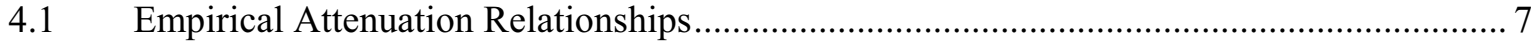

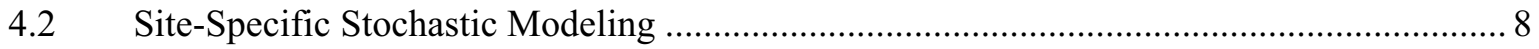

4.2.1 Site-Specific Shear-Wave Velocity Profiles …............................................... 8

4.2.1.1 Geologic Profiles ............................................................. 8

4.2.1.2 Velocity and Density Depth Relationships .................................. 9

4.2.1.3 Smoothed Shear-Wave Velocity Profiles ................................... 11

4.2.2 Kappa Values Based On Empirical Earthquake Recordings............................ 11

4.2.3 Site-Specific Attenuation Relationships.......................................................... 12

4.3 Comparison of Stochastic and Empirical Attenuation Relationships............................... 13

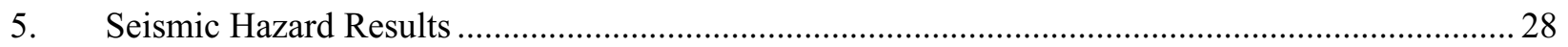

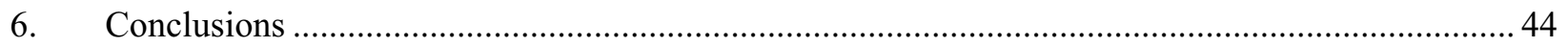

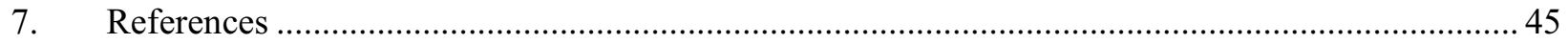


(Intentionally Blank) 


\section{FIGURES}

Figure 1. Map of earthquakes with magnitudes 2.5 and greater occurring from 1872 to 2004 and tectonic setting of INL

Figure 2. Map shows location of normal faults, volcanic zones, drill holes with velocity and density measurements, and INL facility areas.

Figure 3. Logic tree for the 2000 re-computation of the probabilistic seismic hazard analysis 6

Figure 4. Subsurface lithology of deep drill holes at INL.

Figure 5. Basalt velocity-depth relationships and ranges of measured basalt velocities at INL.............. 20

Figure 6. Basalt density-depth relationships and ranges of measured basalt densities at INL. .............. 21

Figure 7. Sedimentary interbed density-depth relationship for INL ................................................ 22

Figure 8. Velocity-depth relationships for sedimentary interbeds at INL......................................... 23

Figure 9. Site-specific and smoothed shear-wave velocity profiles developed for INTEC.

Figure 10. Computed stochastic peak accelerations and generalized attenuation relationship for parameters $\mathrm{Q}=150 f^{0.6}$ and $\kappa=0.024 \mathrm{sec}$ at INTEC

Figure 11. Comparison of INTEC acceleration response spectra (5\% damped) at a distance of $15 \mathrm{~km}$ derived from empirical and stochastic attenuation relationships.

Figure 12. Comparison of INTEC acceleration response spectra (5\% damped) at a distance of $50 \mathrm{~km}$ derived from empirical and stochastic attenuation relationships.

Figure 13. Mean and $5^{\text {th }}$ to $95^{\text {th }}$ percentile seismic hazard curves for INTEC.

Figure 14. Mean seismic hazard for INL facilities.

Figure 15. Comparison of the mean, $5^{\text {th }}$ and $95^{\text {th }}$ percentile seismic hazard and mean hazard of the empirical and stochastic attenuation models for INTEC.

Figure 16. Comparison of the mean, $5^{\text {th }}$ and $95^{\text {th }}$ percentile seismic hazard and mean hazard of the empirical and stochastic attenuation models for RTC.

Figure 17. Comparison of the mean, $5^{\text {th }}$ and $95^{\text {th }}$ percentile seismic hazard and mean hazard of the empirical and stochastic attenuation models for PBF

Figure 18. Comparison of the mean, $5^{\text {th }}$ and $95^{\text {th }}$ percentile seismic hazard and mean hazard of the empirical and stochastic attenuation models for NRF.

Figure 19. Comparison of the mean, $5^{\text {th }}$ and $95^{\text {th }}$ percentile seismic hazard and mean hazard of the empirical and stochastic attenuation models for RWMC. 
Figure 20. Comparison of the mean, $5^{\text {th }}$ and $95^{\text {th }}$ percentile seismic hazard and mean hazard of the empirical and stochastic attenuation models for TAN.

Figure 21. Comparison of the mean, $5^{\text {th }}$ and $95^{\text {th }}$ percentile seismic hazard and mean hazard for the stochastic attenuation model using the three kappa values at INTEC.

Figure 22. Comparison of the mean, $5^{\text {th }}$ and $95^{\text {th }}$ percentile seismic hazard and mean hazard for the stochastic attenuation model using the three kappa values at RTC.

Figure 23. Comparison of the mean, $5^{\text {th }}$ and $95^{\text {th }}$ percentile seismic hazard and mean hazard for the stochastic attenuation model using the three kappa values at PBF.

Figure 24. Comparison of the mean, $5^{\text {th }}$ and $95^{\text {th }}$ percentile seismic hazard and mean hazard for the stochastic attenuation model using the three kappa values at NRF.

Figure 25. Comparison of the mean, $5^{\text {th }}$ and $95^{\text {th }}$ percentile seismic hazard and mean hazard for the stochastic attenuation model using the three kappa values at RWMC.

Figure 26. Comparison of the mean, $5^{\text {th }}$ and $95^{\text {th }}$ percentile seismic hazard and mean hazard for the stochastic attenuation model using the three kappa values at TAN.

Figure 27. Comparison of mean hazard for stochastic attenuation models using the preferred kappa value for each INL facility area. 


\section{TABLES}

Table 1. Empirical attenuation relationships with scaling methods and weighting factors. ................... 14

Table 2. Input parameters and weights for stochastic ground motion attenuation relationships.............. 16

Table 3. Borehole lithology used to develop site-specific geologic profiles for the 1996 PSHA............. 17

Table 4. Site-specific kappa values for INL facility areas................................................................ 18 
(Intentionally Blank) 


\section{ACRONYMS}

ANL

ATR

DBE

DOE

ESRP

INTEC

INL

MFC

NPR

NRC

NRF

PC

PGA

PBF

PSHA

RWMC

RTC

TAN

TRA

UHS
Argonne National Laboratory West

Advanced Test Reactor

Design Basis Earthquake

U.S. Department of Energy

Eastern Snake River Plain

Idaho Nuclear Technology and Engineering Center

Idaho National Laboratory

Materials and Fuels Complex

New Production Reactor

Nuclear Regulatory Commission

Naval Reactor Facility

Performance Category

Peak Ground Acceleration

Power Burst Facility

Probabilistic Seismic Hazard Analysis

Radioactive Waste Management Complex

Reactor Technology Complex

Test Area North

Test Reactor Area

Uniform Hazard Spectra 
(Intentionally Blank) 


\section{Modeling of the Sedimentary Interbedded Basalt Stratigraphy for the Idaho National Laboratory Probabilistic Seismic Hazard Analysis}

\section{Introduction}

The purpose of this report is to summarize how the effects of the sedimentary interbedded basalt stratigraphy were modeled in the probabilistic seismic hazard analysis (PSHA) of the Idaho National Laboratory (INL). The INL is located within the eastern Snake River Plain (ESRP), which is a broad lowrelief basin floored with basaltic lava flows and sediments. Drill holes indicate the bedrock beneath INL facilities is composed of about $1.1 \mathrm{~km}$ of alternating layers of basalt rock and loosely consolidated sediments, which are referred to as sedimentary interbeds. Alternating layers of rock and sediments can attenuate seismic energy to a greater extent than uniform rock. This is because the passage of seismic waves through alternating layers of hard basalt and loosely consolidated (soft) sediments scatter and dampen seismic energy. Such effects were incorporated into seismic hazard analyses for INL facilities.

The PSHA at INL included both empirical attenuation relationships from other regions in the western U. S. principally California and site-specific attenuation relationships derived from stochastic modeling using parameters specific to crustal properties of the ESRP. The empirical attenuation relationships were incorporated into the PSHA to account for the uncertainty of estimating ground motions in an extensional tectonic region with limited empirical data. The stochastic modeling was included to account for possible attenuation effects of the unique sedimentary interbedded basalt stratigraphy beneath INL facilities. Site-specific shear (S-) wave velocity profiles were developed for each INL facility area based on lithology, seismic velocities, and densities observed in several shallow $(<580 \mathrm{~m})$ and four deep $(580-3000 \mathrm{~m})$ drill holes. The site-specific S-wave velocity profiles were used to model the amplification due to the near surface in the PSHA. For stochastic modeling of site-specific attenuation relationships, S-wave velocity profiles were used with recordings of regional earthquakes at INL facilities to determine the near-surface attenuation (or kappa).

Modeling the effects of the sedimentary interbedded basalt stratigraphy has evolved over several INL seismic hazard analyses (Woodward-Clyde Consultants 1990; 1992; Woodward Clyde Federal Services et al. 1996; URS Greiner Woodward Clyde Federal Services et al. 1999; 2000). This report summarizes the relevant aspects of past seismic hazard analyses that support the INL PSHA computations completed in 2000. The report first discusses how the INL PSHA incorporated both empirical and stochastic attenuation relationships. Second, it discusses incorporation of empirical attenuation relationships for extensional tectonic settings in the PSHA. Third, the report discusses the stochastic modeling parameters and how the site-specific S-wave velocity profiles were developed and used in the stochastic modeling of the site-specific attenuation relationships. Finally, the report discusses the contributions of the empirical and stochastic attenuation relationships to the mean seismic hazard at INL facilities. Throughout the discussions of the stochastic modeling effort, the Idaho Nuclear Technology and Engineering Center (INTEC) is used as an example. The 2000 PSHA results are presented for INL facility areas that include the: Naval Reactor Facility (NRF); Power Burst Facility (PBF); Test Area North (TAN); Radioactive Waste Management Complex (RWMC); and Reactor Technology Complex (RTC; which was formerly referred to as the Test Reactor Area or TRA). Seismic hazard results for the Materials and Fuels Complex (MFC) formerly referred to as Argonne National Laboratory West (ANL) are not shown since the seismic hazard analysis for this site was not re-computed in 2000. 


\section{Geologic Setting}

The INL is located in an extensional tectonic region of the northern Basin and Range Province within southeastern Idaho (Figure 1). The INL covers $2300 \mathrm{~km}^{2}$ of the ESRP, which is thought to represent the track of the Yellowstone Hotspot. The hotspot is currently located beneath the Yellowstone National Park, Wyoming. It was centered near INL's location within the ESRP about 4 to 6 million years ago (Pierce and Morgan 1992). Hotspot volcanism first produced large volume silicic eruptions that were followed by predominantly basaltic volcanism. Since the passage of the hotspot, the ESRP has subsided and filled with 1 to $2 \mathrm{~km}$ of basalt lava flows and sediments (Reilinger et al. 1977; Brott et al. 1981; Kuntz et al. 1992; McQuarrie and Rodgers 1998). Today, basalt volcanism appears to be concentrated within several northwest-trending volcanic rift zones and the northeast-oriented axial volcanic zone. Three northwest-trending volcanic rift zones cross the INL (Figure 2). The volcanic rift zone orientations are result of basalt dikes that intruded perpendicular to the NE-SW direction of extension. The most recent basalt volcanism occurred 2,000 year ago south of the INL in the Great Rift volcanic rift zone (Kuntz et al. 1986).

The historical earthquake record (1872-2004; $M>2.5)$ shows the ESRP is aseismic relative to the surrounding seismically active Basin and Range Province (Figure 1). Focal mechanisms for earthquakes within the Basin and Range Province northwest of INL indicate predominantly NE-SW directed extension. This region of the Basin and Range Province is the result of crustal extension that began about 16 million years ago (Rodgers et al. 2002). The southern segments of three northwest-trending Basin and Range normal faults are located along the northwest boundary of the INL (Figure 2). Two large moment magnitude $\left(\mathrm{M}_{\mathrm{w}}\right)$ normal-faulting earthquakes, the $1959 \mathrm{M}_{\mathrm{w}} 7.3$ Hebgen Lake, Montana and $1983 \mathrm{M}_{\mathrm{w}} 7.0$ Borah Peak, Idaho, have occurred within the surrounding basin and range. These large magnitude earthquakes were located more than $80 \mathrm{~km}$ from INL facilities. Although the earthquakes were felt at the INL, they caused no significant damage. 


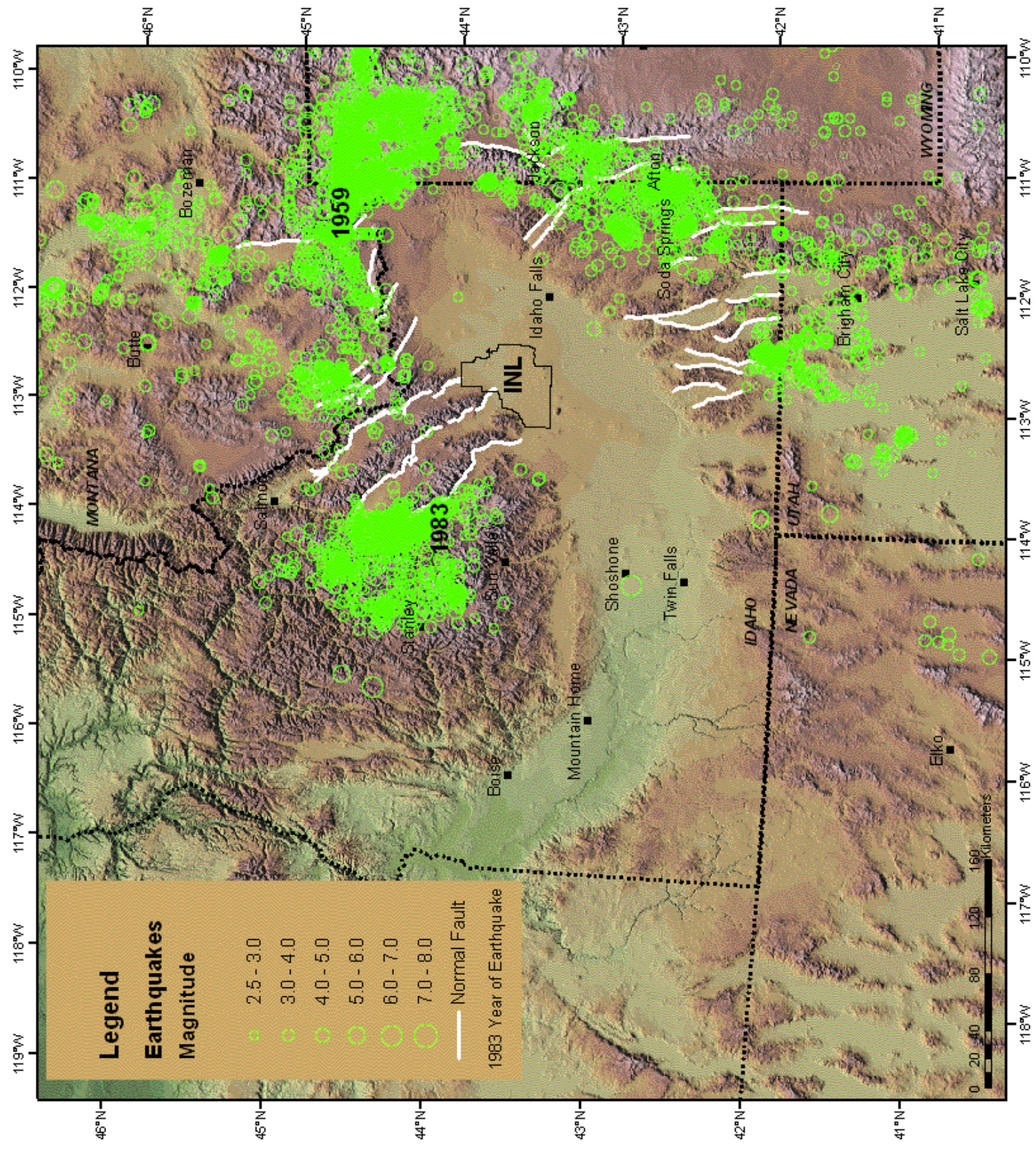

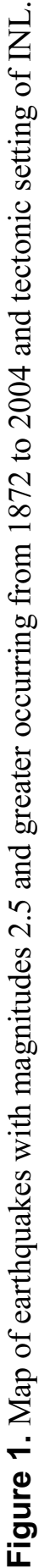




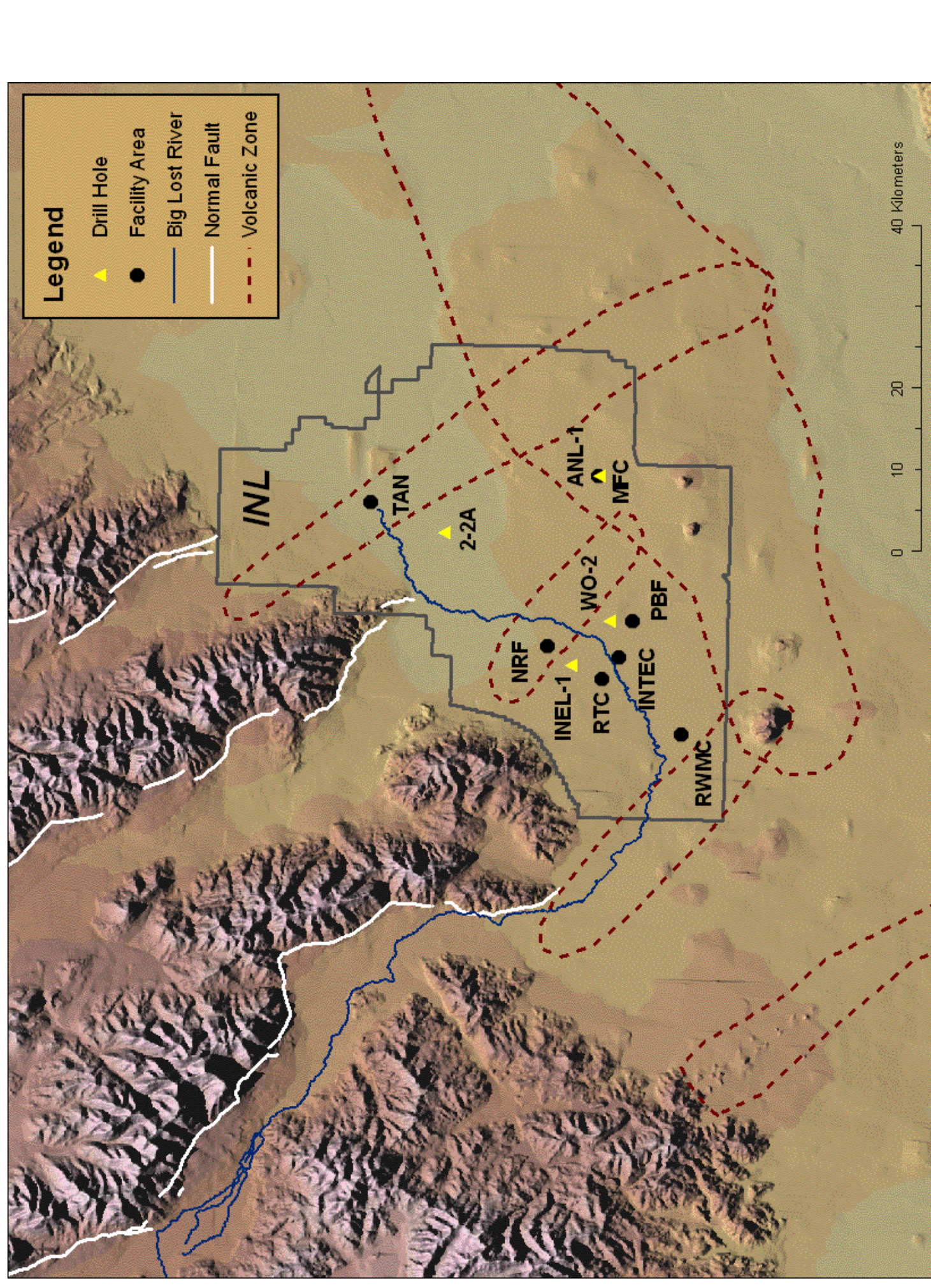

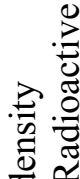

艺

氖

융

云立

30

I

光苍泀

ব

蒠空

$i \geq 0$

ก่

3 可

$\rightarrow$ 西

牙焉志

西

¿ों

ते ค

产空

号

寻主

응

की

के के

. 둥응

ฮี 웡

풍

战宁

范

$\pm \approx$

苛它

웡

岁 㐘

흐를

可

白之通

을

胥

류

잋 壱

语䒿 


\section{INL Probabilistic Seismic Hazard Analysis}

In 1996, the INL completed a comprehensive PSHA resulting in uniform hazard spectra (UHS) for rock conditions at all INL facility areas (Woodward-Clyde Federal Services et al. 1996). The 1996 PSHA built upon the results and reviews of previous PSHA conducted at INL in 1990 and 1992 (WoodwardClyde Consultants 1990; 1992). The 1996 PSHA incorporated results of all available geologic, seismologic, and geophysical investigations conducted since the 1960 's. It provided for explicit inclusion of the range of seismologic and tectonic interpretations for seismic source characterization and ground motion attenuation models. Earthquake magnitudes and recurrence rates were assessed for all earthquake sources including the closest Basin and Range normal faults, dike-induced earthquakes within volcanic rift zones, and background (random) earthquakes within the ESRP, and Basin and Range source zones. Attenuation models included empirical attenuation relationships from other regions and attenuation relationships developed by site-specific stochastic modeling using parameters specific to the ESRP crustal properties. In 2000, the PSHA was recomputed for INL facility areas using the same earthquake source characterization models, but updated attenuation relationships. The empirical and stochastic attenuation relationships were applicable to extensional tectonic settings such as the ESRP and Basin and Range (URS Greiner Woodward Clyde Federal Services et al. 1999; 2000).

The INL PSHA followed the approach developed by Cornell (1968); it estimates the probability that ground motion levels will be exceeded at a site for a specified annual frequency or return period. Uncertainties in conceptual models and parameters were incorporated into the hazard analysis through the use of logic trees (e.g., Youngs et al. 1988). The logic trees allowed for specifying discrete alternatives for the states of nature or parameter values, and the relative likelihood that each discrete alternative is correct. Specific weights were used to estimate the likelihood that a discrete alternative or parameter value is the actual representation.

The first three nodes of the logic tree represented the uncertainty in selecting the appropriate ground motion attenuation relationships. The attenuation relationships were applied to all earthquake sources that were described by branches beyond the attenuation models (Figure 3). Specific weights were assigned to the two attenuation nodes: a weight of 0.4 was assigned to the combined contributions of the empirical attenuation relationships and 0.6 to the site-specific attenuation relationships developed from stochastic modeling. Greater weight was given to the site-specific attenuation relationships because of the unique sedimentary interbedded basalt stratigraphy beneath INL facilities. In the attenuation branches, weights were assigned to each empirical attenuation relationship and to the parameters of the stochastic modeling used to derive the site-specific attenuation relationships (which are discussed in detail in Section 4).

Sensitivity analyses were performed to examine the important contributors to the total hazard and to the uncertainties in the hazard (Woodward-Clyde Federal Services et al. 1996). Based on the PSHA, UHS were calculated for rock conditions at return periods of 500, 1,000, 2,000, and 10,000 yrs corresponding to the hazard levels for the U. S. Department of Energy's (DOE) hazard Performance Categories (PC) at that time (URS Greiner Woodward Clyde Federal Services et al. 1999; 2000). 

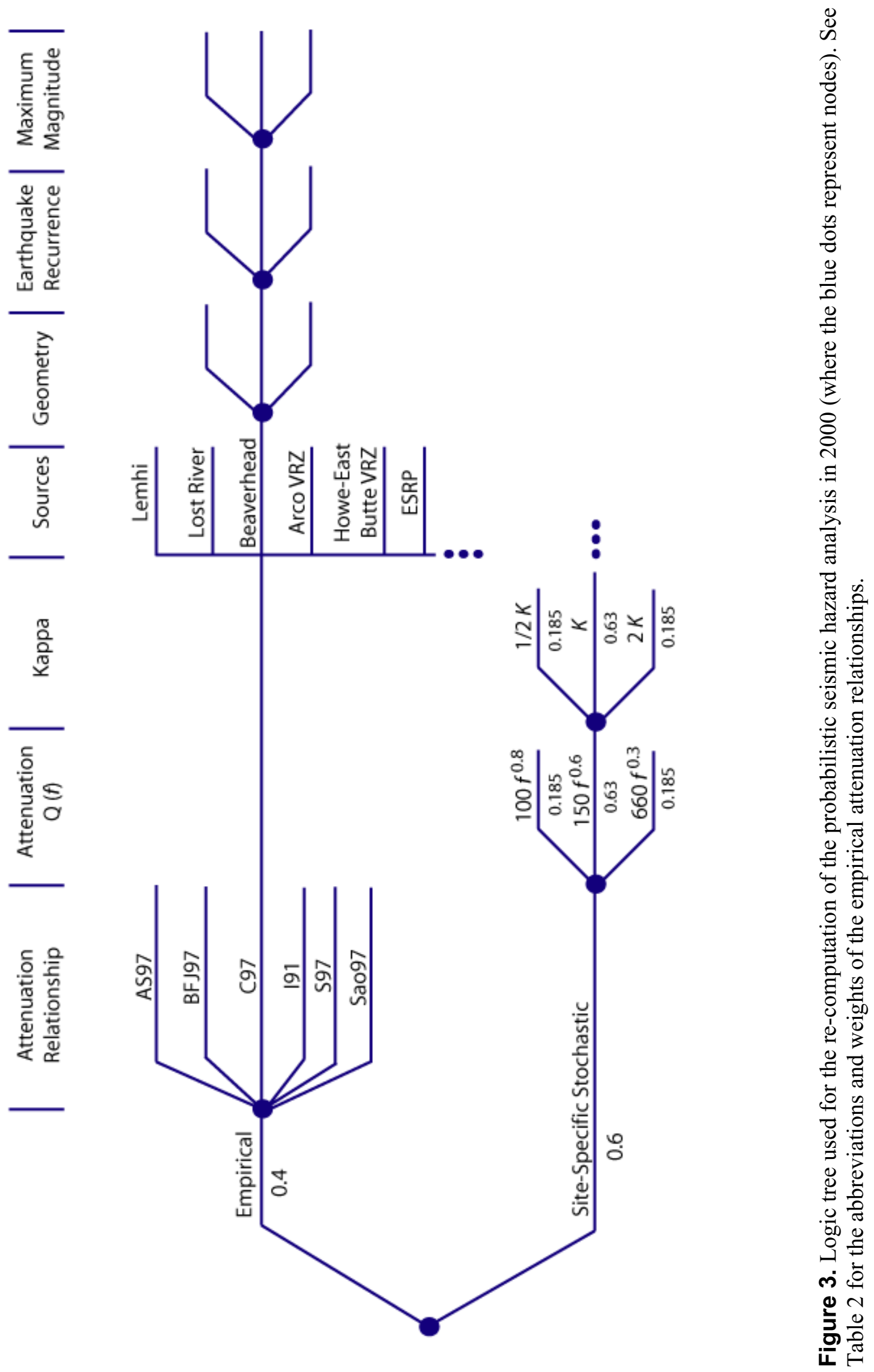


\section{Attenuation Models}

The INL PSHA used an approach that incorporated empirical attenuation relationships from other regions and site-specific attenuation relationships developed from stochastic modeling. This approach was used for two reasons: 1) there is limited empirical strong ground motion data for the ESRP; and 2) the ESRP crust was significantly modified by bimodal volcanism as a result of the passage of the Yellowstone Hotspot (e.g., Armstrong et al. 1975; Sparlin et al. 1982; Peng and Humpreys 1998), whereby the ESRP has been filled with 1 to $2 \mathrm{~km}$ of basalt lava flows and sediments. For the hazard recomputation in 2000, empirical attenuation relationships for extensional tectonic settings were used in the PSHA. The site-specific stochastic modeling incorporated a range of stress drops representative of normal faulting earthquakes and attenuation effects based on the unique subsurface geology of the ESRP.

\subsection{Empirical Attenuation Relationships}

The 2000 PSHA incorporated empirical attenuation relationships developed for an extensional tectonic regime (Figure 3). Six empirical attenuation relationships were combined with four alternative scaling factors, similar to the approach used for the Yucca Mountain (YM) PSHA (URS Greiner Woodward Clyde Federal Services et al. 1999; 2000). Originally, ground motion experts for the YM study selected seven alternative empirical attenuation relationships to estimate strong ground motions resulting from normal faulting earthquakes. The attenuation relationships included Abrahamson and Silva (1997), Boore et al. (1997), Campbell (1997), Idriss (1991; University of California, Davis written communications, 1997), Sadigh et al. (1997), Spudich et al. (1997), and Sabetta and Pugliese (1996). For the INL PSHA, the Sabetta and Pugliese (1996) relationship was not used since it does not differentiate between strike-slip and reverse earthquakes and was used by only one YM expert resulting in a combined average relative weight of less than one percent. The relative weights of the YM expert panel for empirical relationships were re-normalized to account for this change (URS Greiner Woodward Clyde Federal Services et al. 1999).

Four alternative scaling relationships were used to adjust the empirical relationships for earthquake source differences between California strike-slip earthquakes and normal faulting earthquakes. The first scaling method uses no scaling based on the assumption there is no significant difference between faulting styles. The second method uses a set of empirical adjustment factors developed by Norm Abrahamson to adjust the Abrahamson and Silva (1997) attenuation relationships from strike-slip to normal faulting. The third scaling method is one-half of the empirical adjustment factors developed by Dr. Abrahamson, which was used by the YM expert panel. The fourth method uses a set of scale factors developed from point-source stochastic ground motion modeling and differences in stress drops between California strike-slip and extensional normal faulting earthquakes. Using stochastic modeling approaches, Ken Campbell and Walt Silva produced scale factors that resulted in similar values. Dr. Silva's scaling factors were used since they have a convenient numerical expression that can be used to adjust the coefficients of the empirical attenuation relationships. Table 1 lists the empirical attenuation relationships, scale factors, and relative weights used in the re-computation of the INL PSHA (URS Greiner Woodward Clyde Federal Services et al. 1999).

The YM ground motion experts also developed modifications of the empirical models for travel path and local site effects. For the YM PSHA, the travel path effects were incorporated by evaluation of the effect of the difference in anelastic attenuation between California and southern Nevada. The anelastic attenuation was parameterized by the quality factor $\mathrm{Q}(f)=\mathrm{Q}_{0} f^{\eta}$; where $f$ is the frequency of the seismic wave. The best estimates for the path effects in the ESRP crust, $\mathrm{Q}_{o}=150$ and $\eta=0.6$ (Woodward-Clyde Federal Services et al. 1996), are similar to that for California, so no adjustments were made. 
The PSHA produced ground motion estimates for rock surface conditions, so a "rock" site category was used in the attenuation relationships. Since Campbell (1997) differentiated between hard and soft rock, Campbell's hard rock empirical relationship was used in the INL analysis due to the high shearwave velocities of the basalt rock (URS Greiner Woodward Clyde Federal Services et al. 1999). Additionally, the scaling methods listed in Table 1 were used to adjust the attenuation relationships to WUS rock sites that are applicable to INL.

\subsection{Site-Specific Stochastic Modeling}

The Band-Limited-White-Noise (BLWN) Random-Vibration-Theory (RVT) approach was used to develop the site-specific attenuation relationships for the INL PSHA. The BLWN-RVT point-source ground motion model employs the $\omega^{2}$ Brune point-source model (Brune 1970; 1971) with a single-corner frequency and a constant stress parameter (Boore 1983; Atkinson 1984). The acceleration spectral density $\mathrm{a}(f)$ for shear waves was modeled using site-specific parameters for stress drop $(\Delta \sigma)$, crustal attenuation $\left(\mathrm{Q}_{0}\right.$ and $\left.\eta\right)$, near-surface crustal attenuation (kappa were or $\kappa(0)$ ), and near-surface crustal amplification (see Appendix A for equations). The site-specific parameters for stress drop, crustal attenuation, and nearsurface attenuation were varied to incorporate the range of uncertainty based on the available knowledge of these parameter values. Table 2 lists the parameter values with their respective weights for the stress parameter, crustal attenuation, and point source magnitudes and focal depths. The reader is referred to the 1996 and 2000 PSHA reports for additional information on these parameters and their selected weights (Woodward-Clyde Federal Services et al. 1996; URS Greiner Woodward Clyde Federal Services et al. 2000).

The following two subsections discuss the site-specific S-wave velocity profiles and kappa since both inputs included the effects of the sedimentary interbedded basalt stratigraphy for the stochastic modeling. S-wave velocity profiles were developed from the subsurface geology observed in boreholes and available seismic velocities measured at INL. The S-wave velocity profiles were smoothed based on an approach developed to match regional earthquakes recorded at the 3-km deep drill hole INEL-1. The near-surface attenuation was modeled using the parameter kappa. Values of kappa were determined from an inversion of waveform data for regional earthquakes recorded at INL facility areas.

\subsubsection{Site-Specific Shear-Wave Velocity Profiles}

In the PSHA, amplification due to the near-surface velocity gradient was accounted for in the sitespecific S-wave velocity profile developed at each facility area. To develop site-specific S-wave velocity profiles, first detailed geologic profiles were developed from lithology observed in boreholes at each facility area and four deep drill holes (580-3000 m depth). Second, seismic velocities and densities were assigned to the stratigraphic layers using seismic velocity and density relationships. Seismic velocity measurements with consideration of analog data from other areas were used to develop individual S-wave and compressional (P) wave velocity relationships as a function of depth for rock (basalt and rhyolite) and sediments. A similar approach was used to develop density-depth relationships. S-wave velocity and density values were assigned to each stratigraphic layer at the layer's corresponding depth range of the velocity- and density-depth relationships. Finally, the site-specific S-wave velocity profiles were smoothed using a spatial smoothing window of $31-\mathrm{m}$, which was determined by comparison with regional earthquake recordings.

\subsubsection{Geologic Profiles}

Much of what is known of the subsurface geologic conditions at INL is based on shallow boreholes, four deep drill holes, and geophysical investigations (Figure 2). The lithologic logs for two deep drill holes INEL-1 and WO-2 show a sequence of alternating layers of basalt lava flows and poorly 
consolidated sediments that extend from the surface to a depth of $1100 \mathrm{~m}$ (Figure 4). The basalt-sediment sequence overlies rhyolitic deposits associated with Yellowstone Hotspot volcanism (Doherty 1979a; 1979b; Doherty et al. 1979; Hackett and Smith 1992). The thickness of sedimentary interbeds range from 0 to $97 \mathrm{~m}$ with thicker interbeds occurring within the deeper parts of the basalt sections. In general, higher percentages of sedimentary interbeds are observed in boreholes located within the Big Lost River drainage region, which is closer to the northwest boundary of the ESRP (Figure 2). Lower numbers of sedimentary interbeds are observed in boreholes to the east near the center of the ESRP (Appendix B; Figure B-1). The absence of sedimentary interbeds near the central part of the ESRP is due to the numerous basaltic eruptions that formed a topographically higher region within the Axial Volcanic Zone along the northeast-trending axis of the ESRP (Figure 2).

At each facility area, detailed geologic profiles were developed using lithologic information from boreholes that extended to depths less than $580 \mathrm{~m}$. Lithologic profiles from nearby deep wells were added to the bottoms of the geologic profiles to extend them to a depth of $3000 \mathrm{~m}$ (Table 3). For example at INTEC, lithology from three boreholes were used to describe the distribution and thickness of sedimentary interbeds within the near-surface basalt section to a depth of $229 \mathrm{~m}$. Below this depth, the basalt-sediment section and top of rhyolitic deposits observed in drill hole WO-2 (229-1524 $\mathrm{m}$ ) and the rhyolite section observed in INEL-1 were appended to the profile (1524-3000 m). In development of the geologic profiles, not all sedimentary interbeds were included within the basalt section. Sedimentary interbeds were included if they could be identified on lithologic as well as geophysical logs, otherwise they were ignored (Per. Comm. R. P. Smith 2005).

\subsubsection{Velocity and Density Depth Relationships}

Seismic velocity- and density-depth relationships were developed using measurements at INL and with consideration of appropriate analog relationships from other regions. At INL, S- and P- wave velocities for basalt and sediments have been measured as part of geotechnical investigations for building foundations. Seismic velocity measurements to depths less than $100 \mathrm{~m}$ were acquired using standard techniques such as seismic refraction, down-hole, cross-hole, and suspension logging. At deeper depths, $\mathrm{P}$-wave velocities of basalts and rhyolites have been measured using sonic and suspension logging within drill holes that contain these units (ANL-1, 2-2A, and INEL-1). Two drill holes (2-2A and INEL-1) have P-wave velocity measurements within sedimentary units at deeper depths $(200,700$, and $800 \mathrm{~m})$. Densities for basalt and sediments are from in-situ measurements (near-surface), laboratory measurements of samples (near-surface and deep cores), and density logging within the deep drill holes (2-2A, INEL-1, and WO-2). Appendix B discusses details of the available seismic velocity and density measurements for basalt, rhyolite and sedimentary interbeds at INL.

The following summarizes the approaches used to develop the seismic velocity-and density-depth relationships.

- Basalt and Rhyolite Seismic Velocity-Depth Relationships - The S- and P-wave velocity-depth relationships follow measured seismic velocities within the basalt section from the surface to depths of 375 and $600 \mathrm{~m}$, respectively. The P-wave velocity-depth relationship is consistent with the measured velocities within the basalt and rhyolite section from 600 to $3000 \mathrm{~m}$ depth (2-2A and INEL-1). A Poisson ratio of 0.30 for basalt and rhyolite was used to estimate the S-wave velocitydepth relationship from 375 to $3000 \mathrm{~m}$ depth. Figure 5 shows the basalt velocity-depth relationship with the measured seismic velocities. For comparison, the P-wave velocities of INL basalts are more consistent with that of ocean floor basalts (e.g., Purdy 1982; Bratt and Purdy 1984; Wilkins et al. 1991) except at shallow depths of 0-50 $\mathrm{m}$ where INL velocities are lower due to unsaturated conditions, numerous open fractures, sediment infilling of fractures, and rubble zones. At depths of 0.5 to $1 \mathrm{~km}$, INL basalts have slightly lower velocities than those of the Columbia River basalts 
(Jarchow and Catchings 1994), which is attributed to INL basalt having thinner flows, numerous rubble zones, abundant fractures, and sediment infilling of fractures near flow tops (see Appendix B; Figure B-2).

- Basalt and Rhyolite Density-Depth Relationship - The starting basalt density was anchored to the average density calculated for basalt measurements at the near surface. The density-depth relationship was extended from this value at the surface to a depth of $1100 \mathrm{~m}$ using basalt density measurements in drill holes 2-2A, INEL-1, and WO-2 (Figure 6). The slope of the density-depth relationship was then extended to $3000 \mathrm{~m}$ with consideration of the range of densities for basalt $\left(2.5\right.$ to $\left.3.0 \mathrm{gm} / \mathrm{cm}^{3}\right)$ and rhyolite $\left(2.4\right.$ to $\left.2.5 \mathrm{gm} / \mathrm{cm}^{3}\right)$.

- $\quad$ Sedimentary Interbed Density-Depth Relationship - The measured densities of sedimentary interbeds at INL have inconsistencies or unusual characteristics that contribute to uncertainty about the densities applicability (Appendix B). Laboratory measurements of interbed sediment samples in drill hole 2-2A vary widely and, in some cases, result in densities that are significantly higher than the densities measured by borehole logging for the same depth range (Figure 7). Sediments in drill hole INEL-1 at about $700 \mathrm{~m}$ depth (below the bottom of the basalt section) contain high percentages of volcanic ash (tuff). Therefore these sediments may not be representative of the nonvolcanic fine-grained terrigenous sediments that comprise the bulk of the sedimentary interbeds in other boreholes. Due to the large variations in measured densities, density-depth relationships for analogous sediment types for other areas were considered. The fine-grained sediments (silty clays) for the Gulf Coast density-depth relationship (Dobrin 1952) are most analogous to INL interbed sediments. The sedimentary interbed density-depth relationship was developed by first anchoring the density at the surface to in situ densities measured in shallow soil pits at INL. The relationship was then extended through the density range estimated from density logs of drill hole 2-2A at about $200 \mathrm{~m}$ depth. Finally, the sedimentary interbed density-depth relationship was merged with the relationship for Gulf Coast sediments at about $400 \mathrm{~m}$ depth and to deeper depths (Figure 7).

- $\quad$ Sedimentary Interbed Velocity-Depth Relationship - The limited measured seismic velocity data for sedimentary interbeds at INL were compared to velocities for analogous young sediment types of other areas. The P-wave velocity measurements of INL sedimentary interbeds compared most favorably with the velocity-depth relationships of Gardner et al. (1974) and Faust (1951) for shales and sands. The P-wave velocity-depth relationship was constructed using the velocity measurements of sediments at the surface. It was then matched to a P-wave velocity-depth relationship calculated using the sedimentary interbed density-depth relationship shown in Figure 6 (and equation: $\rho=0.23 \mathrm{Vp}^{0.25}$ where $\rho$ is density and $\mathrm{Vp}$ is P-wave velocity; Gardner et al. 1974). This approach was used to maintain internal consistency between velocities and densities of the sedimentary interbeds. The resulting P-wave velocity-depth relationship for INL sedimentary interbeds is similar to the Gardner et al. (1974) relationships for average shales and sands (Figure 8). The S-wave velocity-depth relationship was calculated using a Poisson's ratio of 0.35 for sediments.

The site-specific S-wave velocity and density profiles for each facility area (Woodward-Clyde Federal Services et al. 1996; Appendix E) were computed using the S-wave velocity-depth and densitydepth relationships for basalt (Figures 5 and 6, respectively) and sedimentary interbeds (Figures 8 and 7 , respectively). The depth ranges of each stratigraphic unit of the site-specific geologic profiles were plotted on the S-wave velocity-depth and density-depth relationships. The S-wave velocity and density values were read from the relationships at the corresponding depth range of each stratigraphic unit. As an example, Figure 9 shows the site-specific S-wave velocity profile for INTEC (Appendix C has all INL facility $\mathrm{S}$-wave profiles). 


\subsubsection{Smoothed Shear-Wave Velocity Profiles}

The site-specific S-wave velocity profiles for each facility area were smoothed with a spatial smoothing window. This approach was taken in the modeling because the initial velocity model for 3000 $\mathrm{m}$ deep drill hole INEL-1 produced response spectra that contained larger oscillations at high frequencies than the spectra of several regional earthquakes recorded at INEL-1. As part of the microearthquake survey undertaken in 1989, a seismic station was installed at the surface of drill hole INEL-1 and recorded six regional earthquakes (Woodward-Clyde Consultants 1990). The modeled spectra also had comparatively lower amplitudes than the observed spectra due to the unusual amount of scattering in the model from large velocity contrasts between the rock and sedimentary interbeds. As a result of the poor initial fits, the S-wave velocity profiles were smoothed to improve the matches of the modeled spectra to the recorded spectra at INEL-1 (Woodward-Clyde Consultants 1990).

The optimum smoothing window was determined by using different smoothing window lengths for the velocity profiles, computing the response spectra, and comparing them to the spectra of earthquakes recorded at INEL-1. The interpolation of the profiles began at one-meter layers with smoothing that employed a triangular-weighted running window. The layers were recombined if velocities in adjacent layers were within $2 \%$ of each other, which somewhat reduces the total number of layers. The recombination factor of $2 \%$ was determined by producing response spectra using velocity profiles which had no recombined layers (1-m layers) and comparing with spectra using the velocity profiles that had recombined layers. At $2 \%$ recombination, the spectra were indistinguishable whereas higher factors resulted in larger deviations. Window lengths ranged from 1 to $51 \mathrm{~m}$. A window of $31 \mathrm{~m}$ was chosen as the optimum length because the oscillations at high frequencies were closer to the recorded data at INEL1 (Woodward-Clyde Consultants 1990).

For the INL PSHA, the 31-m smoothing window was used to smooth the site-specific S-wave velocity profiles for all INL facility areas. In general, smoothing the S-wave velocity profiles had the effect of decreasing the number and the amount of the impedance contrasts between the basalt and sediment velocities. As an example, Figure 9 shows the smoothed S-wave velocity profile for INTEC that was used in the 2000 PSHA (see Appendix C for other INL facilities).

\subsubsection{Kappa Values Based On Empirical Earthquake Recordings}

The near-surface attenuation was represented by kappa, which was determined from an inversion of regional earthquake data recorded at INL facility areas. Inversion of the regional earthquake data was used to estimate site-specific values for the parameters kappa, $\mathrm{Q}_{0}, \eta, \mathrm{M}_{\mathrm{w}}$ and corner frequency $\left(f_{\mathrm{c}}\right)$ (see Appendix A). The parameters were calculated for three different earthquake data sets using a nonlinear least-squares inversion of the log of the Fourier amplitude spectra for the stochastic model parameters (Woodward-Clyde Federal Services et al. 1996). To improve the fit to the earthquake spectra at INL recording sites, transfer functions were computed from the smoothed site-specific S-wave velocity profiles to account for the near-surface amplification. The transfer functions were used in the inversion.

The inversion data sets included: 1) regional earthquakes recorded by temporary seismic stations located at INL facility areas, 2) two regional earthquakes recorded by a 1993 temporary broadband array that extended across the ESRP and was operated by the University of Oregon, and 3) aftershocks of the $1983 \mathrm{M}_{\mathrm{w}}$ 7.0 Borah Peak earthquake recorded by a temporary array near the epicentral region. In 1989, temporary digital seismic stations were installed for about four months at INL facility areas to record regional earthquakes. Temporary stations at all but two facility areas, NRF and INTEC, recorded earthquake data (Woodward-Clyde Consultants 1990). The combined earthquake data set for the inversion had 91 recordings ranging from local magnitude $\left(\mathrm{M}_{\mathrm{L}}\right) 2.8$ to 5.1 at hypocentral distances of 7 to 230 km (Woodward-Clyde Federal Services et al. 1996). 
Inversions of regional earthquake data provided estimates of kappa for each INL facility area. The number of observations used in the inversions for each facility area varied from 0 to 11 . The kappa values ranged from a low value of $0.012 \mathrm{sec}$ at MFC to $0.033 \mathrm{sec}$ at PBF (Table 4). The log-average kappa for the INL is $0.024 \mathrm{sec}$, which is at the lower end of typical western U.S. rock values $(0.01$ to $0.06 \mathrm{sec})$. The lower kappa values at INL are attributed to the relatively dense, high-velocity basalts, which allow for a more efficient transfer of high-frequency seismic energy up through the site-specific geologic profiles. However, this effect appears to be offset somewhat by the presence of low velocity sedimentary interbeds within the basalt section beneath different facility areas. MFC has the lowest kappa value and has the fewest sedimentary interbeds (Figure 4), whereas RTC, TAN, RWMC, and PBF have higher kappa values and more interbeds since they are located within the floodplain of the Big Lost River. The log-average kappa of $0.024 \mathrm{sec}$ was assigned to INTEC and NRF, since these sites lacked site-specific kappa estimates (Woodward-Clyde Federal Services et al. 1996).

Kappa was varied explicitly in the stochastic modeling to develop the site-specific attenuation relationships (URS Greiner Woodward-Clyde Federal Sevices et al. 1999; 2000). Due to the limited regional earthquake recordings, kappa was varied by a factor of two (Table 4). The distribution of weights assigned to the site-specific kappa values were 0.630 for the best estimate determined from the inversion and 0.185 for values of kappa that are larger and smaller by a factor of two (Table 2). The distribution of weights $0.185,0.630$, and 0.185 approximates the $5^{\text {th }}, 50^{\text {th }}$, and $95^{\text {th }}$ percentile values, respectively. This approach of a three-point approximation and specific weights for the median and selected percentiles for input parameters of the logic tree in the INL PSHA is based on studies of Keefer and Bodily (1983).

\subsubsection{Site-Specific Attenuation Relationships}

Point-source stochastic modeling was used to develop site-specific attenuation relationships for each facility area. Point-source ground motions were simulated for magnitudes and source-to-site distances that incorporated parametric variability. The simulations were performed using a magnitudedependent distribution of point-source depth and a distribution of stress drops to represent the randomness in ground motions from earthquake to earthquake (Table 2). The simulated spectral accelerations were used to develop attenuation relationships using a regression method with a functional form typically used in developing attenuation relationships of empirical ground motion data (see Appendix A for equations). The point-source depths used in the analysis were varied based on estimated depth ranges of earthquakes as function of magnitude. The variation of point-source depths changed the distance from the source to the site in the stochastic modeling.

In the 2000 PSHA of INTEC, for example, multiple attenuation relationships were developed from the stochastic modeling. The stress drop had four values (median and three values weighted about the median), the crustal attenuation had a preferred value of $\mathrm{Q}_{0}=150$ and $\eta=0.6$ and two other values (Table 2), and kappa had a preferred value of $0.024 \mathrm{sec}$ and two other values that vary by a factor of \pm 2 (Table 4). The site geology was represented by the smoothed site-specific S-wave velocity profile (Figure 9). Each magnitude $\left(\mathrm{M}_{\mathrm{w}} 5,6,7\right.$, and 7.5) had a distribution of focal depths (Table 2). To develop an attenuation relationship as a function of magnitude and distance, the stochastic computation resulted in 12 acceleration data points at a distance $(\mathrm{R})$ representing the random variation in stress drop and focal depths for earthquakes of a given magnitude (Figure 10). This process was repeated to develop nine attenuation relationships for each site to account for the uncertainty in $\mathrm{Q}(\mathrm{f})$ and kappa. Thus, the stochastic modeling developed multiple alternative attenuation relationships to estimate the ground motions levels at INTEC. The nine stochastic attenuation relationships had a combined weight of 0.6 in the PSHA (Figure 3). 


\subsection{Comparison of Stochastic and Empirical Attenuation Relationships}

Acceleration response spectra at 5\% damping derived from the stochastic and empirical attenuation relationships are compared for INTEC at distances of 15 and $50 \mathrm{~km}$ (Figures 11 and 12). The stochastic attenuation relationships were computed for three values of $\mathrm{Q}(f)$ (Table 2) and kappa (Table 4). The empirical attenuation relationships are for those listed in Table 1 adjusted by the WSSC scaling factors. At $15 \mathrm{~km}$ distance, the acceleration response spectra show the stochastic attenuation relationships for the three $\mathrm{Q}(f)$ values and kappa $=0.012$ have the greatest exceedance over the empirical attenuation relationships at spectral periods of 0.02 to $0.10 \mathrm{sec}$ and $\mathrm{M}_{\mathrm{w}} 7.0$ (Figure 11). At $50 \mathrm{~km}$, the acceleration spectra for the stochastic attenuation relationships span a greater range of spectral acceleration for three values of $\mathrm{Q}(f)$ and the same kappa value (Figure 12). As a result, acceleration spectra for some of the empirical attenuation relationships exceed or match those for the stochastic attenuation relationship except for spectral periods of 0.02 and $0.10 \mathrm{sec}$ when $\mathrm{Q}=670 f^{0.3}$ and kappa $=0.012 \mathrm{sec}$ (Figure 12). Overall, Figures 11 and 12 show the acceleration spectra of the empirical attenuation relationships envelop the acceleration spectra for the stochastic attenuation relationships with the preferred kappa value of $0.024 \mathrm{sec}$ and the three alternative $\mathrm{Q}(\mathrm{f})$. The acceleration response spectra of the stochastic attenuation relationships only exceed those of the empirical attenuation relationships at lower kappa values and shorter distances. 
Table 1. Empirical attenuation relationships with scaling methods and weighting factors.

\begin{tabular}{|c|c|c|}
\hline $\begin{array}{l}\text { Rock Site Attenuation Relationship } \\
\text { (and Abbreviation) }\end{array}$ & $\begin{array}{c}\text { Earthquake Source Scaling } \\
\text { Method }^{\mathrm{a}}\end{array}$ & Re-normalized Weights \\
\hline & None & 0 \\
\hline Abrahamson and Silva (1997) & A-E & 0.223 \\
\hline \multirow[t]{4}{*}{$(\mathrm{AS} 97)$} & $1 / 2 \mathrm{~A}-\mathrm{E}$ & 0.036 \\
\hline & $\mathrm{KCSC}$ & 0.051 \\
\hline & WSSC & 0.014 \\
\hline & None & 0.006 \\
\hline Boore et al. (1997) & A-E & 0.014 \\
\hline \multirow{4}{*}{ (BFJ97) } & $1 / 2 \mathrm{~A}-\mathrm{E}$ & 0.036 \\
\hline & $\mathrm{KCSC}$ & 0.042 \\
\hline & WSSC & 0.050 \\
\hline & None & 0.006 \\
\hline Campbell (1997) & A-E & 0.029 \\
\hline \multirow{4}{*}{ (C97) } & $1 / 2 \mathrm{~A}-\mathrm{E}$ & 0.036 \\
\hline & $\mathrm{KCSC}$ & 0.051 \\
\hline & WSSC & 0.036 \\
\hline & None & 0.006 \\
\hline Idriss (1991; 1997) & $A-E$ & 0.014 \\
\hline \multirow[t]{4}{*}{ (I91) } & $1 / 2 \mathrm{~A}-\mathrm{E}$ & 0 \\
\hline & $\mathrm{KCSC}$ & 0.051 \\
\hline & WSSC & 0.022 \\
\hline & None & 0.006 \\
\hline Sadigh et al. (1997) & A-E & 0.029 \\
\hline \multirow[t]{3}{*}{ (S97) } & $1 / 2 \mathrm{~A}-\mathrm{E}$ & 0.036 \\
\hline & $\mathrm{KCSC}$ & 0.051 \\
\hline & WSSC & 0.022 \\
\hline
\end{tabular}


Table 1. Continued.

\begin{tabular}{ccc}
\hline $\begin{array}{c}\text { Rock Site Attenuation Relationship } \\
\text { (and Abbreviation) }\end{array}$ & $\begin{array}{c}\text { Earthquake Source Scaling } \\
\text { Method }^{\mathrm{a}}\end{array}$ & Re-normalized Weights \\
\hline $\begin{array}{c}\text { Spudich et al. (1997) } \\
\text { (Sao97) }\end{array}$ & None & 0.116 \\
KCSC & 0.018 \\
$\begin{array}{l}\text { a. A-E developed by Norm Abrahamson; } 1 / 2 \text { A-E recommended by Yucca Mountain expert panel; KCSC } \\
\text { developed by Ken Campbell; WSSC developed by Walt Silva. Note: Walt Silva's scaling factors were used for } \\
\text { both KCSC and WSSC (URS Greiner Woodward Clyde Federal Services et al. (1999). }\end{array}$ \\
\hline
\end{tabular}


Table 2. Input parameters and weights for stochastic ground motion attenuation relationships.

\begin{tabular}{ccc}
\hline Parameter & Value & Weight \\
$\Delta \sigma$ & $25^{\mathrm{a}}$ & 0.20 \\
& 50 & 0.60 \\
& 75 & 0.15 \\
$\kappa$ & 150 & 0.05 \\
& $1 / 2 \kappa$ & 0.185 \\
& $\kappa$ & 0.630 \\
Q $f$ ) & $2 \kappa$ & 0.185 \\
& $100 f^{0.8}$ & \\
$\mathrm{M}_{\mathrm{w}} 5$ & $150 f^{0.6}$ & 0.185 \\
& $670 f^{0.3}$ & 0.630 \\
& $4 \mathrm{~km}$ & 0.185 \\
$\mathrm{M}_{\mathrm{w}} 6$ & $8 \mathrm{~km}$ & 0.185 \\
Point Source Focal Depth & $12 \mathrm{~km}$ & 0.630 \\
& & 0.185 \\
Point Source Focal Depth & $6 \mathrm{~km}$ & 0.185 \\
$\mathrm{M}_{\mathrm{w}} 7$ & $9 \mathrm{~km}$ & 0.630 \\
Point Source Focal Depth & $12 \mathrm{~km}$ & 0.185 \\
& & \\
$\mathrm{M}_{\mathrm{w}} 7.5$ & $8 \mathrm{~km}$ & 0.185 \\
Point Source Focal Depth & $10 \mathrm{~km}$ & 0.630 \\
& $12 \mathrm{~km}$ & 0.185
\end{tabular}


Table 3. Borehole lithology used to develop site-specific geologic profiles for the 1996 PSHA.

\begin{tabular}{|c|c|c|c|c|}
\hline Facility Area $^{a}$ & $\begin{array}{l}\text { Boreholes Used to } \\
\text { Develop Detailed } \\
\text { Geologic Layers }\end{array}$ & $\begin{array}{l}\text { Depth Range for } \\
\text { Detailed Borehole } \\
\text { Lithology }(\mathrm{m}) \\
\end{array}$ & $\begin{array}{c}\text { Deep Drill Hole Used } \\
\text { for Appended } \\
\text { Lithology }^{b} \\
\end{array}$ & $\begin{array}{l}\text { Depth Range of } \\
\text { Appended } \\
\text { Lithology }(\mathrm{m}) \\
\end{array}$ \\
\hline $\begin{array}{l}\text { MFC } \\
\text { (ANL) }\end{array}$ & ANL-1 & $0-576$ & $\begin{array}{l}\text { WO-2 } \\
\text { INEL-1 }\end{array}$ & $\begin{array}{c}576-1524 \\
1524-3000\end{array}$ \\
\hline INTEC & $\begin{array}{l}\text { USGS-048 } \\
\text { USGS-121 } \\
\text { USGS-123 }\end{array}$ & $0-229$ & $\begin{array}{l}\text { WO-2 } \\
\text { INEL-1 }\end{array}$ & $\begin{array}{c}229-1524 \\
1524-3000\end{array}$ \\
\hline NRF & $\begin{array}{l}\text { B18-1 } \\
\text { STR-1 }\end{array}$ & $0-163$ & INEL-1 & $163-3000$ \\
\hline $\mathrm{PBF}$ & SPERT-1 & $0-365$ & $\begin{array}{l}\text { WO-2 } \\
\text { INEL-1 }\end{array}$ & $\begin{array}{c}365-1524 \\
1524-3000\end{array}$ \\
\hline RWMC & Corehole C1A & $0-544$ & $\begin{array}{l}\text { WO-2 } \\
\text { INEL-1 }\end{array}$ & $\begin{array}{c}544-1500 \\
1500-3000\end{array}$ \\
\hline TAN & $\begin{array}{c}\text { IET-1 } \\
\text { USGS-07 }\end{array}$ & $0-366$ & $\begin{array}{l}\text { CH2-2A } \\
\text { INEL-1 }\end{array}$ & $\begin{array}{c}366-914 \\
914-3000\end{array}$ \\
\hline $\begin{array}{l}\text { RTC } \\
\text { (TRA) }\end{array}$ & TRA Disposal Well & $0-382$ & INEL-1 & $382-3000$ \\
\hline
\end{tabular}


Table 4. Site-specific kappa values for INL facility areas.

\begin{tabular}{|c|c|c|c|c|}
\hline Facility Area $^{a}$ & $\begin{array}{c}\text { Number of Earthquake } \\
\text { Observations }\end{array}$ & $\begin{array}{c}\text { Kappa } \\
(\mathrm{sec})\end{array}$ & $\begin{array}{c}1 / 2 \text { Kappa } \\
(\mathrm{sec})\end{array}$ & 2 x Kappa (sec) \\
\hline MFC (ANL) & 8 & 0.012 & 0.006 & 0.024 \\
\hline RTC (TRA) & 1 & 0.020 & 0.010 & 0.040 \\
\hline INTEC & 0 & $0.024^{\mathrm{b}}$ & 0.012 & 0.048 \\
\hline NRF & 0 & $0.024^{\mathrm{b}}$ & 0.012 & 0.048 \\
\hline PBF & 2 & 0.033 & 0.016 & 0.066 \\
\hline RWMC & 5 & 0.021 & 0.010 & 0.042 \\
\hline TAN & 11 & 0.021 & 0.010 & 0.042 \\
\hline
\end{tabular}




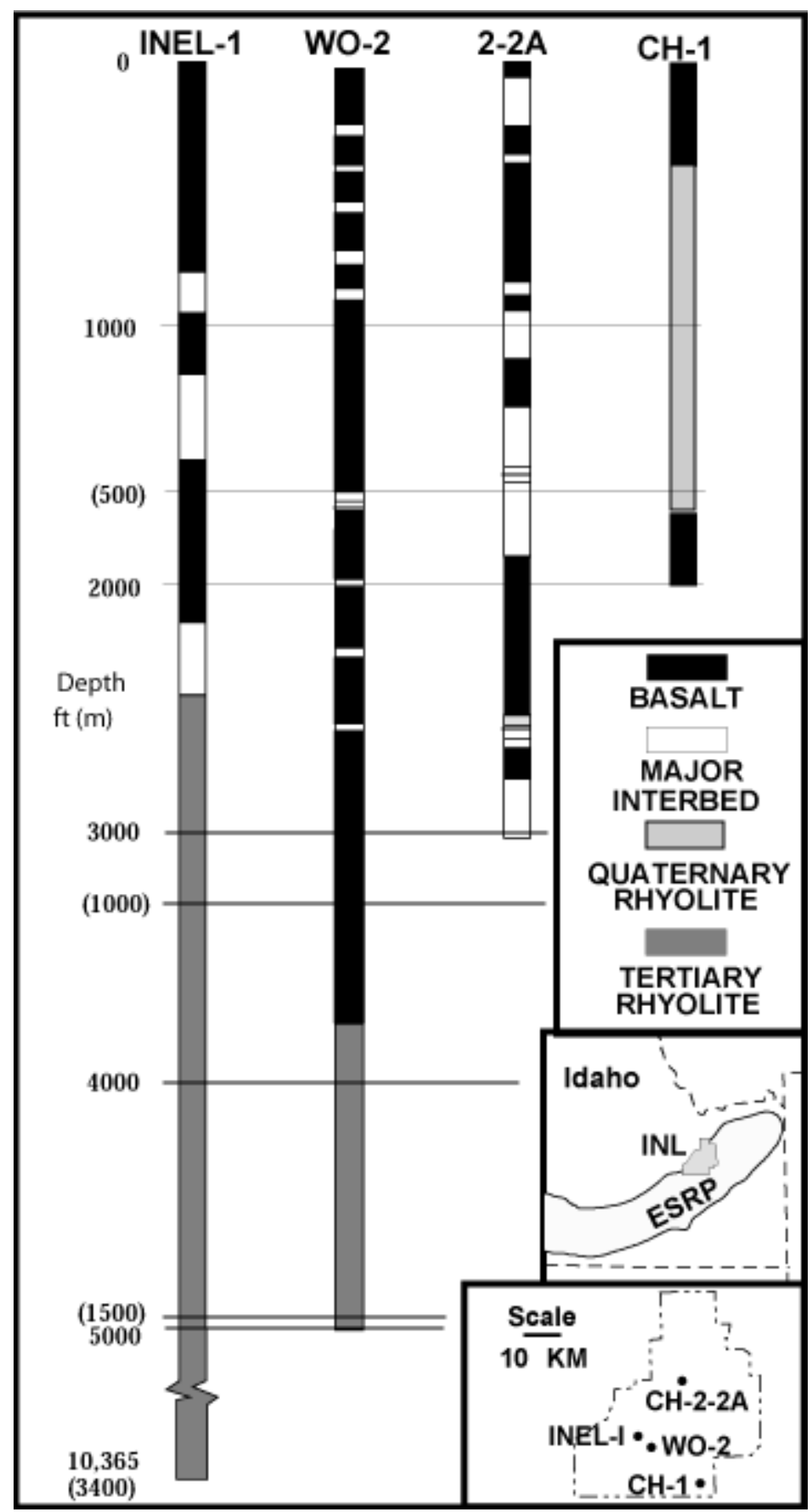

Figure 4. Subsurface lithology of deep drill holes at INL. 


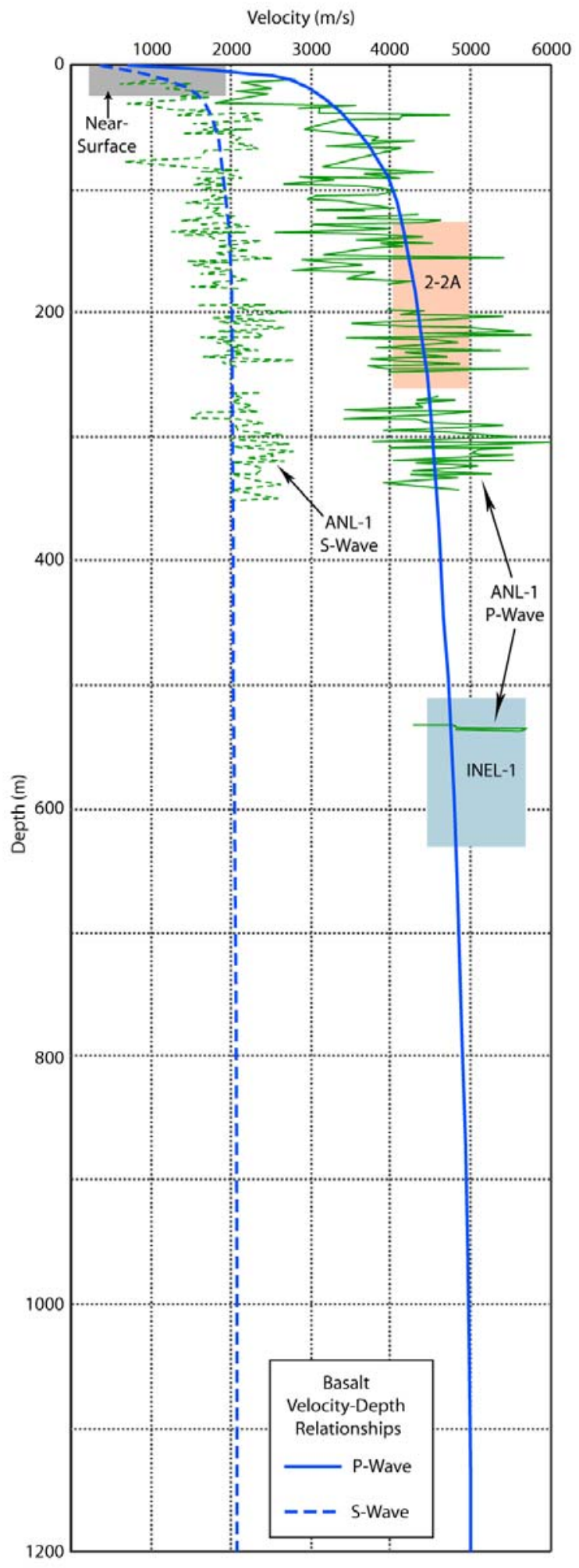

Figure 5. Basalt velocity-depth relationships and ranges of measured basalt velocities at INL for: nearsurface P-wave measurements (gray box); drill hole 2-2A (orange box); drill hole INEL-1 (blue box); and suspension logging in drill hole ANL-1 (P-wave - green lines; S-wave - dashed green lines). 


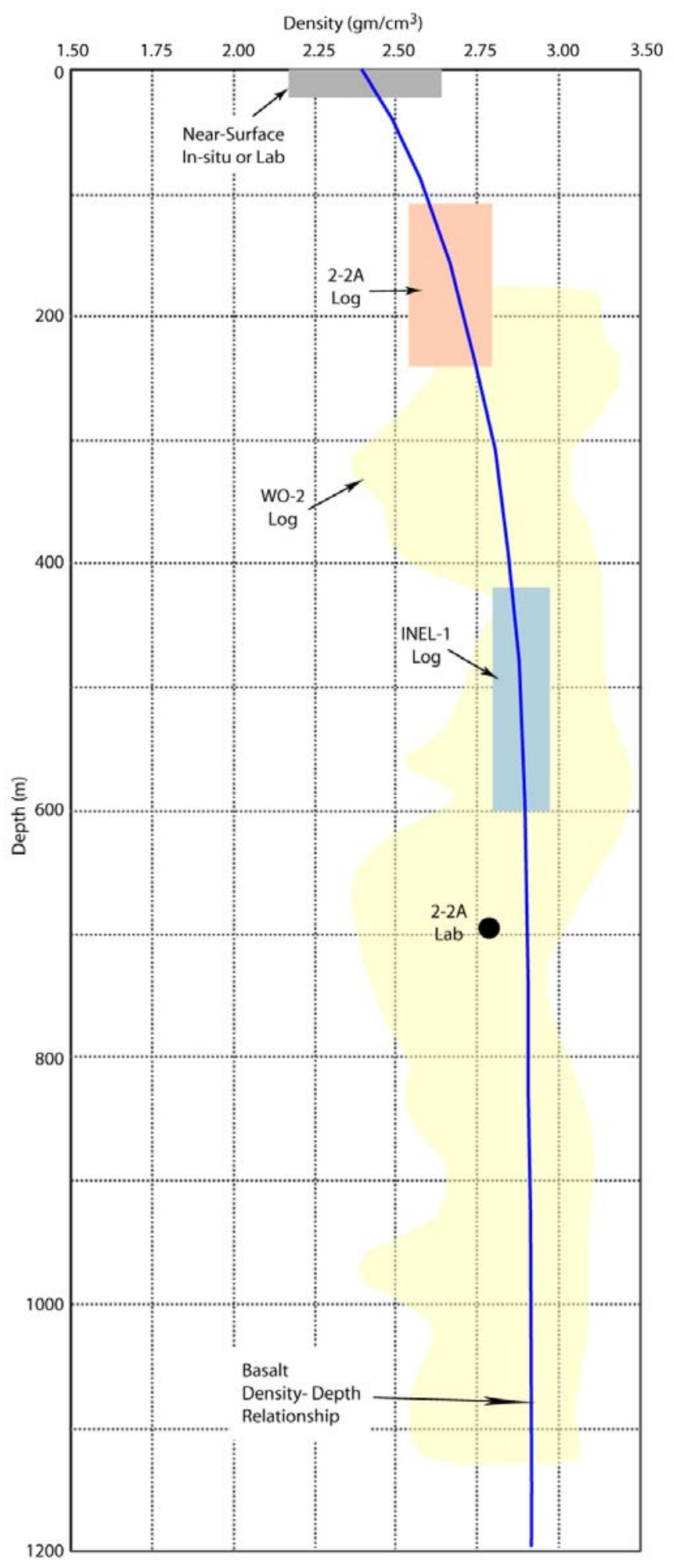

Figure 6. Basalt density-depth relationships and ranges of measured basalt densities at INL for: nearsurface in-situ and laboratory measurements (gray box), drill hole 2-2A laboratory measurements (black dot), and density logs in drill holes 2-2A (orange box), INEL-1 (blue box), and WO-2 (yellow region). 


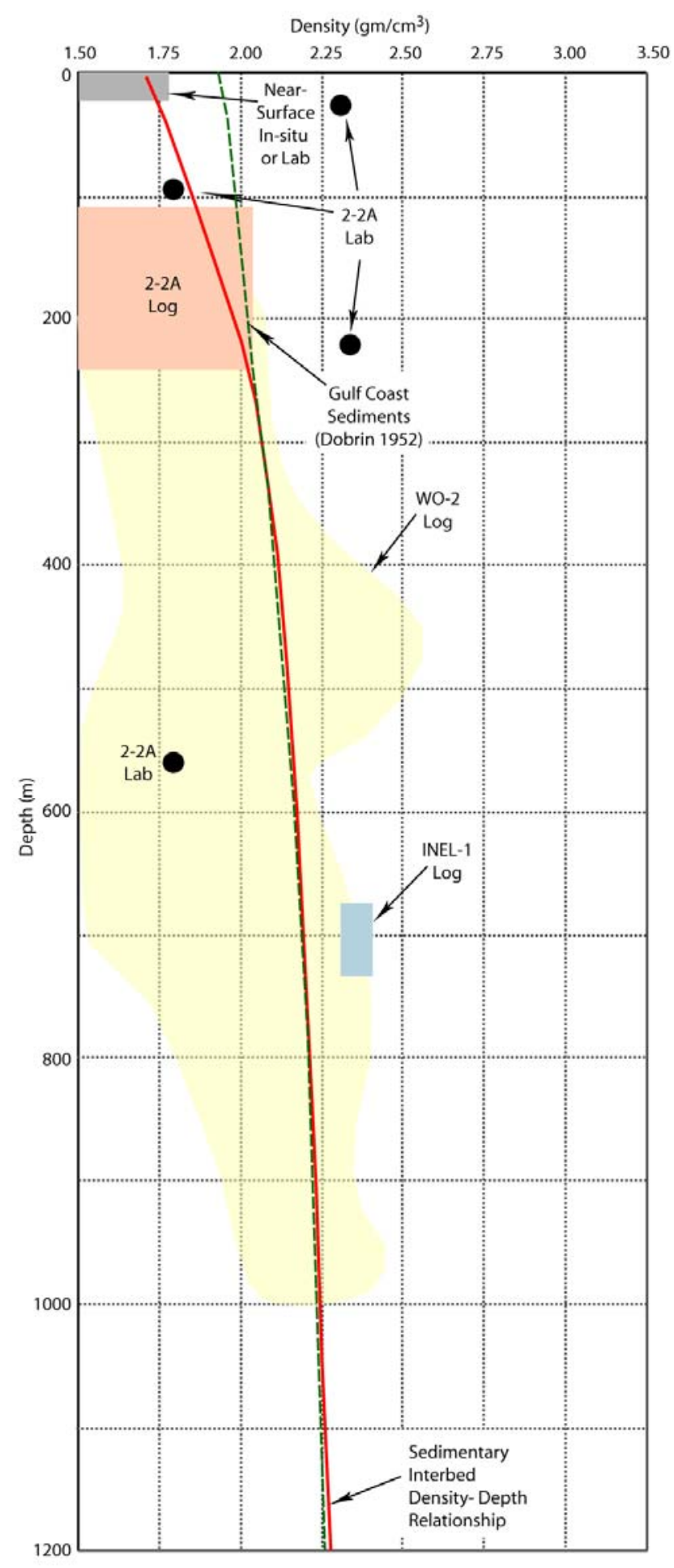

Figure 7. Sedimentary interbed density-depth relationship for INL, Gulf Coast sediment relationship (green dashed line; Dobrin 1952) and ranges of measured sediment densities at INL for: near-surface insitu and laboratory measurements (gray box), drill hole 2-2A laboratory measurements (black dots), and density logs in drill holes 2-2A (orange box), INEL-1 (blue box), and WO-2 (yellow region). 


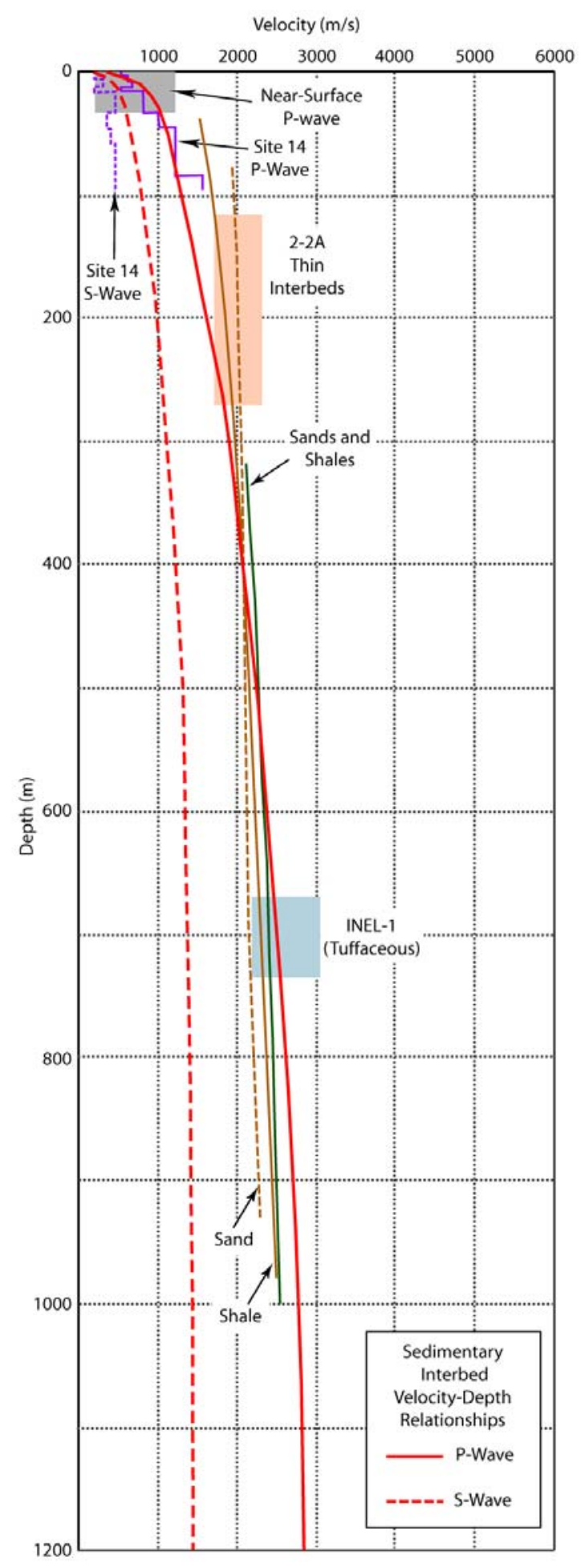

Figure 8. Velocity-depth relationships for sedimentary interbeds at INL and ranges of measured sediment velocities at INL for: near-surface P-wave velocity measurements (gray box); drill hole Site 14 (P-wave - purple line; S-wave - purple dashed line); drill hole 2-2A (orange box); and drill hole INEL-1 (blue box). Other P-wave velocity relationships are for average sand (brown dashed line) and shale (brown line) of Gardner et al. (1974) and various sands and shales of Faust (1951). 


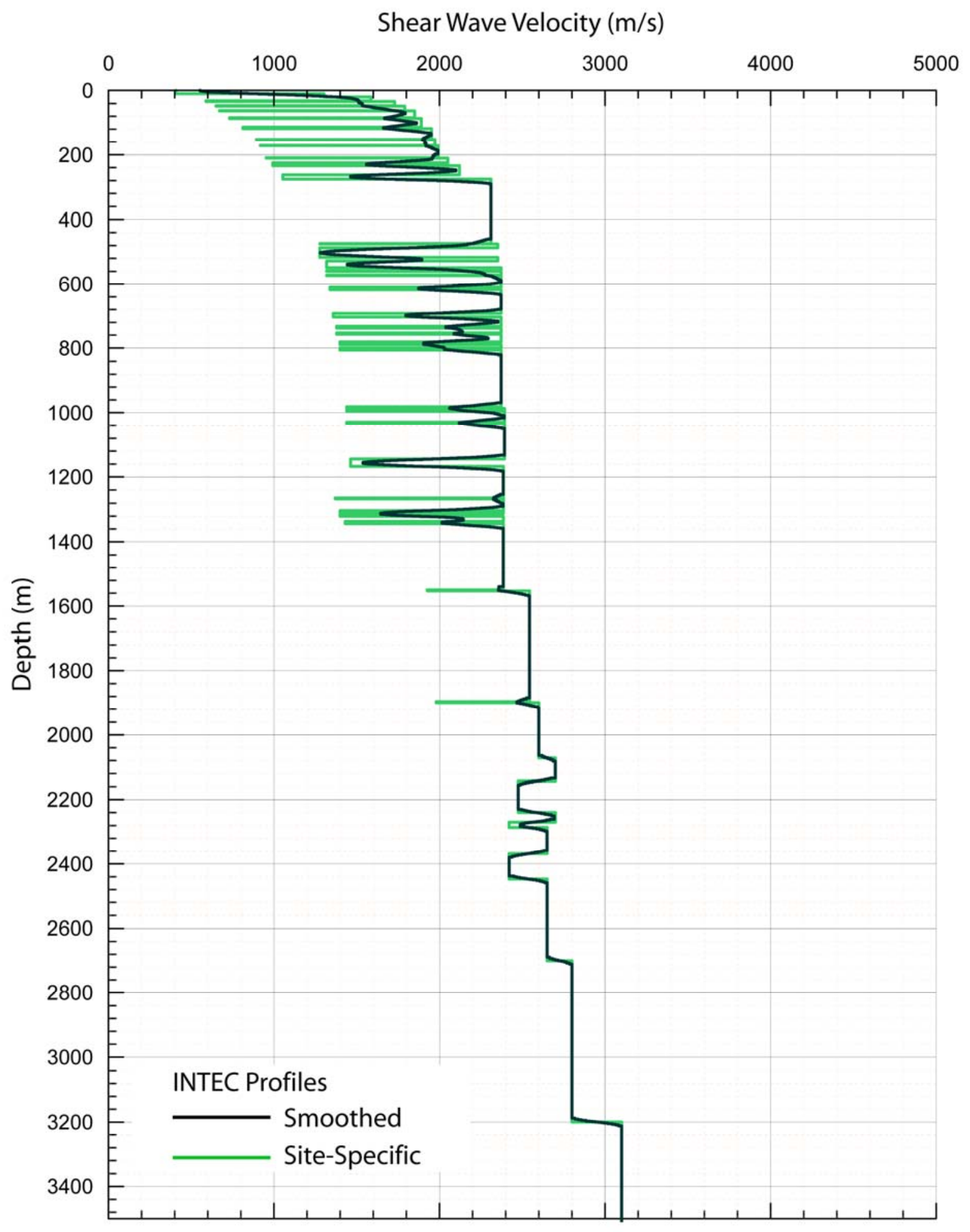

Figure 9. Site-specific and smoothed shear-wave velocity profiles developed for INTEC (WoodwardClyde Federal Services et al. 1996). 

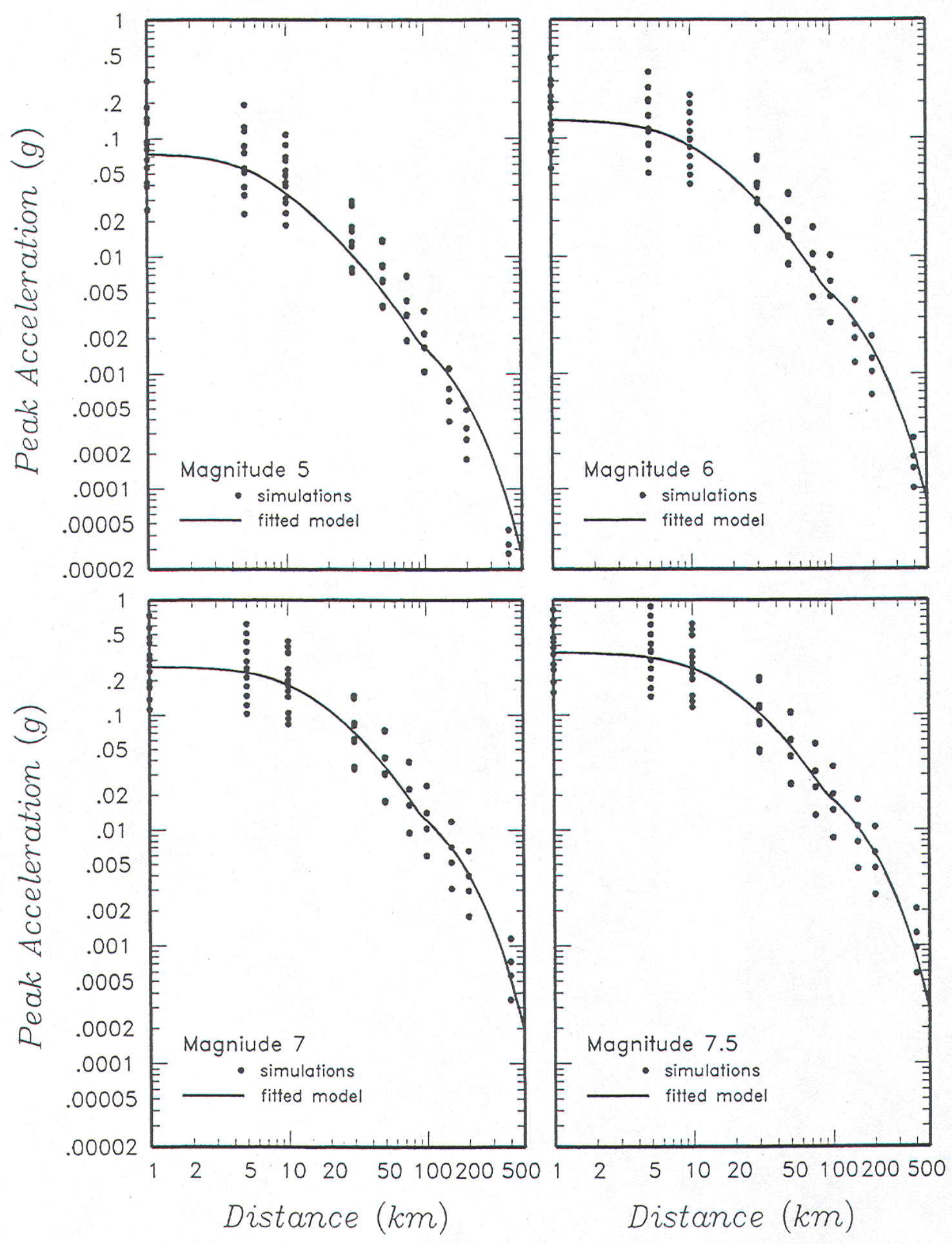

Figure 10. Computed stochastic peak accelerations and generalized attenuation relationship for parameters $\mathrm{Q}=150 f^{0.6}$ and $\kappa=0.024 \mathrm{sec}$ at INTEC (URS Greiner Woodward Clyde Federal Services et al. 1999). 

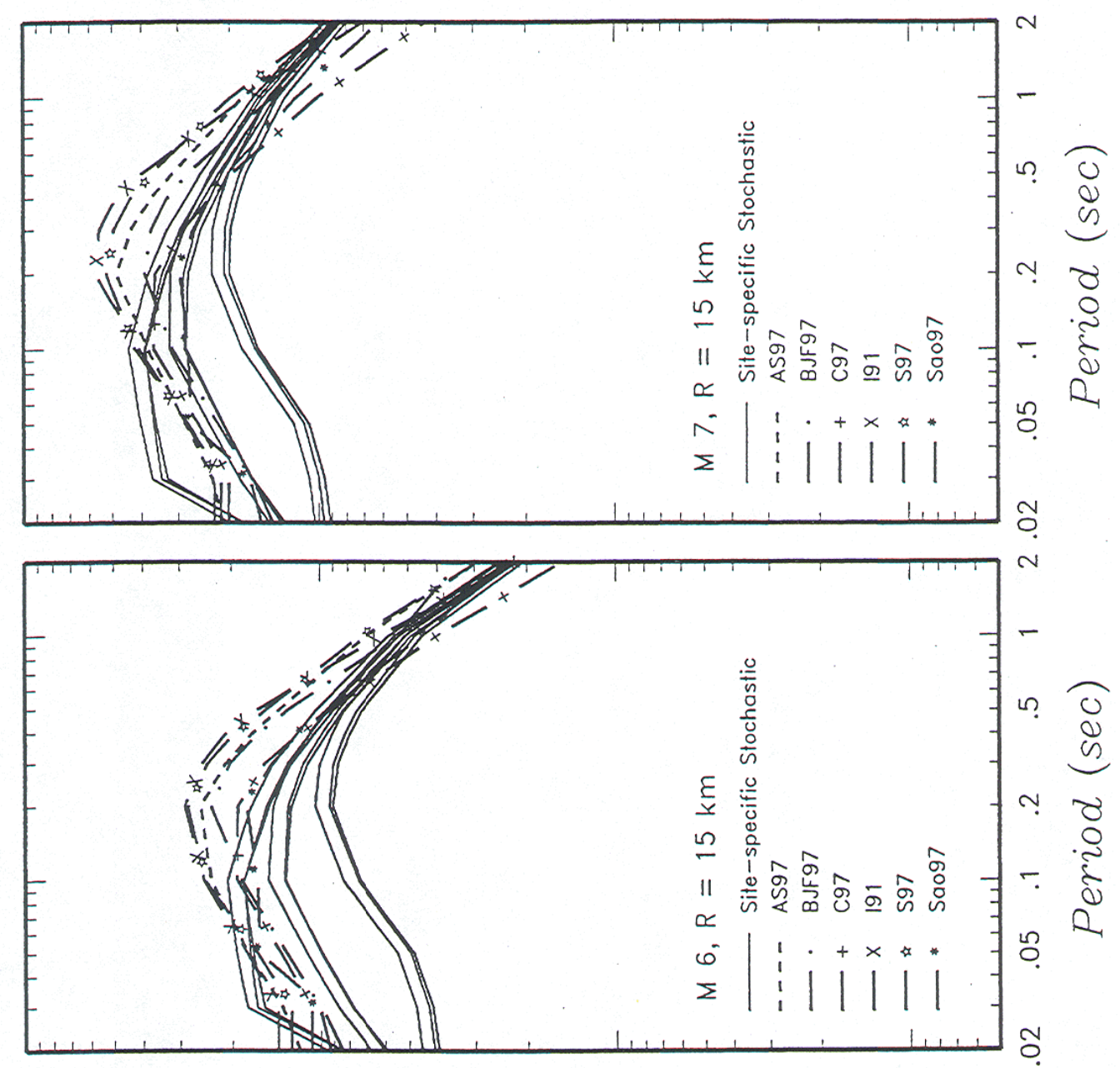

$N$
-
0
$?$
-
0
0
0

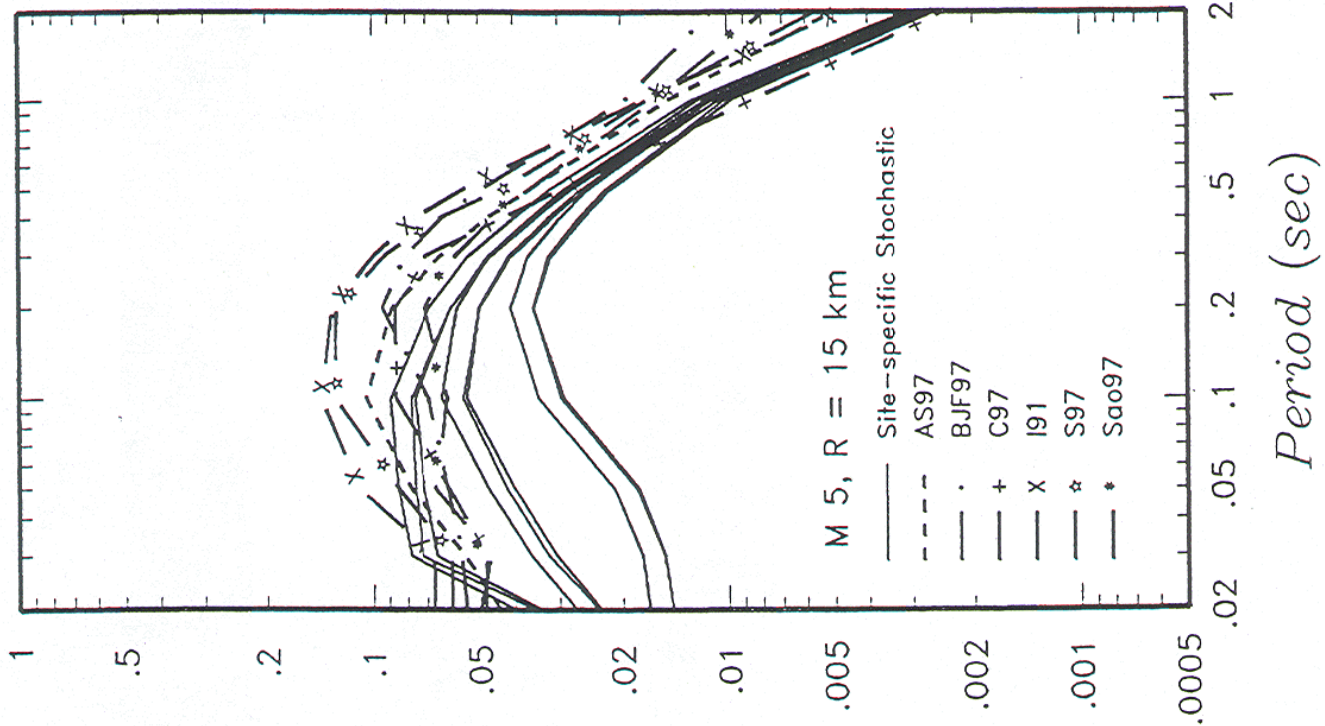

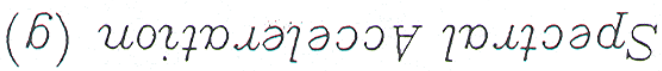

on

䨌

क O 3

की क्ष

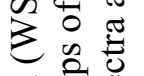

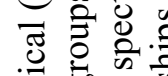

कू

훙혀

궁 웡

局要

离命远

元

멍

$\because$ 융

虫

800

峝 䨌

(0) :

()

त

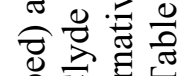

氙式

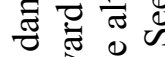

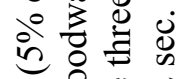

I)

远。

की.

词言

을 可

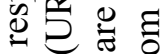

o w o t

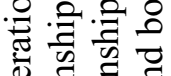

응 흐

政

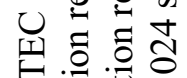

它踪

फ $\overline{0}$ ⿹

○.

혀ㅇㅝㅠ

$\therefore$ 至造

을 흉 क्षे

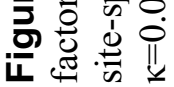




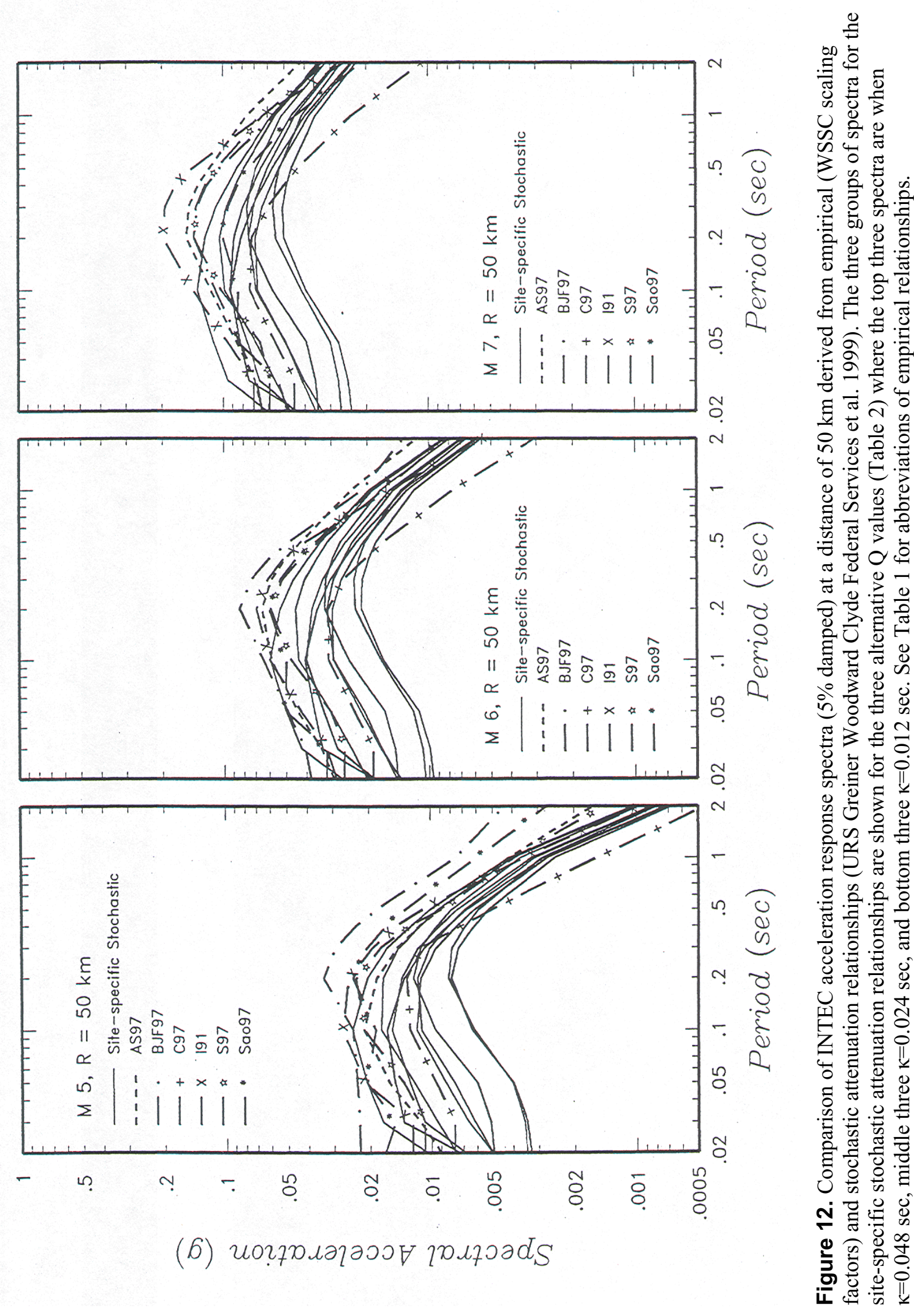

$\hat{\imath}$ 


\section{Seismic Hazard Results}

The seismic hazard was calculated for rock at the peak horizontal acceleration (assumed to be 0.02 sec or $50 \mathrm{~Hz}$ ) and 5\%-damped response spectral accelerations of $0.03,0.05,0.1,0.2,0.3,0.4,0.5,1.0$, and $2.0 \mathrm{sec}(33,20,10,5,3.3,2.5,2,1$, and $0.5 \mathrm{~Hz}$, respectively). For each facility area, the total mean hazard and the $5^{\text {th }}-15^{\text {th }}-, 50^{\text {th }}-, 85^{\text {th }}$-, and $95^{\text {th }}$ - percentile hazard were computed for the input parameter distributions defined by the hazard model logic trees. The logic trees represent the best judgment of the uncertainty in defining input parameters and thus the computed distributions represent the confidence in the estimated hazard.

For all facility areas at INL, the range of uncertainty about the total mean hazard varies from about one order of magnitude at low ground motion levels to one and one half orders of magnitude at large accelerations. The distribution in computed frequency of exceedance is moderately skewed at all higher ground motion levels, with the mean lying near the $75^{\text {th }}$-percentile of the hazard distribution. The width of the distribution in the computed hazard ranges from one to one and one-half orders of magnitude in exceedance frequency (URS Greiner Woodward Clyde Federal Services et al. 1999; 2000). Figure 13 shows the computed mean hazard curves for INTEC at peak horizontal acceleration and spectral accelerations of 0.1 and $1 \mathrm{sec}(10$ and $1 \mathrm{~Hz}$, respectively). The peak horizontal accelerations at INTEC for return periods of 2,000 and 10,000 yrs were computed at $0.11 \mathrm{~g}$ and $0.18 \mathrm{~g}$, respectively (URS Greiner Woodward Clyde Federal Services et al. 1999). Among the INL facility areas, TAN has the highest mean hazard because of its proximity to the active Basin and Range faults and regional source zone (Figure 1). PBF has the lowest mean hazard because of its relatively high near-surface attenuation (or kappa). The mean hazard for RTC, INTEC, NRF, and RWMC are generally similar (Figure 14).

The relative contribution of uncertainty in selecting the appropriate type of attenuation model was evaluated by giving full weight (1.0) to each attenuation model (stochastic or empirical). Figures 15 through 20 show the mean, $5^{\text {th }}$, and $95^{\text {th }}$ hazard with weights of 0.4 for empirical and 0.6 for stochastic relationships relative to the hazard computed for each attenuation model with a weight of 1.0. For all facility areas, the uncertainty band of ground motions is greater at periods of 0.02 and $0.1 \mathrm{sec}$ than at 1.0 sec. At all three periods, the hazard computed from the empirical attenuation relationships exceeds the hazard from the stochastic attenuation relationships. This difference is attributed to the damping effects of the sedimentary interbeds within the basalt section and the relatively low velocity gradient in the basalts compared to a typical western U. S. rock site.

The relative contribution of uncertainty of kappa was also evaluated. Figures 21 through 26 show the mean, $5^{\text {th }}$, and $95^{\text {th }}$ hazard curves with (weights of 0.4 for empirical and 0.6 for stochastic) relative to the hazard from the stochastic attenuation relationships computed for three kappa values (Table 4) for each facility area. The comparisons show the uncertainty band of ground motions is greater at periods of 0.02 and $0.1 \mathrm{sec}$ than at the period of $1.0 \mathrm{sec}$. Finally, Figure 27 shows the mean hazard of the stochastic attenuation models for kappa at each facility area. As observed, the variation in kappa results in a significant variation in hazard at short periods $(0.02$ and $0.1 \mathrm{sec})$. PBF, with the highest kappa $(0.033 \mathrm{sec})$, has the lowest mean hazard whereas the other facility areas have similar mean hazard levels and kappa values $(0.020-0.024 \mathrm{sec})$. 

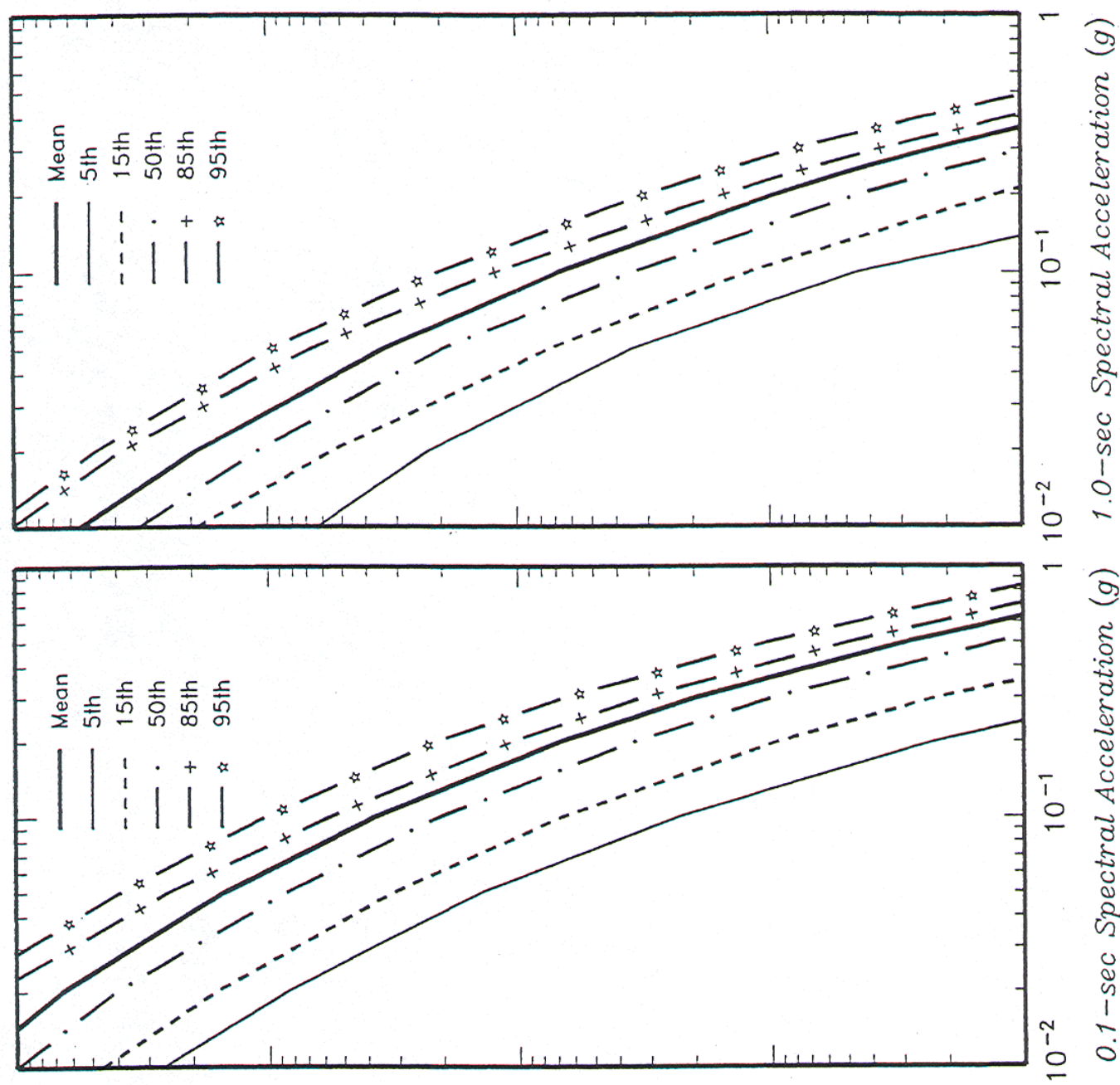

ㄴ.

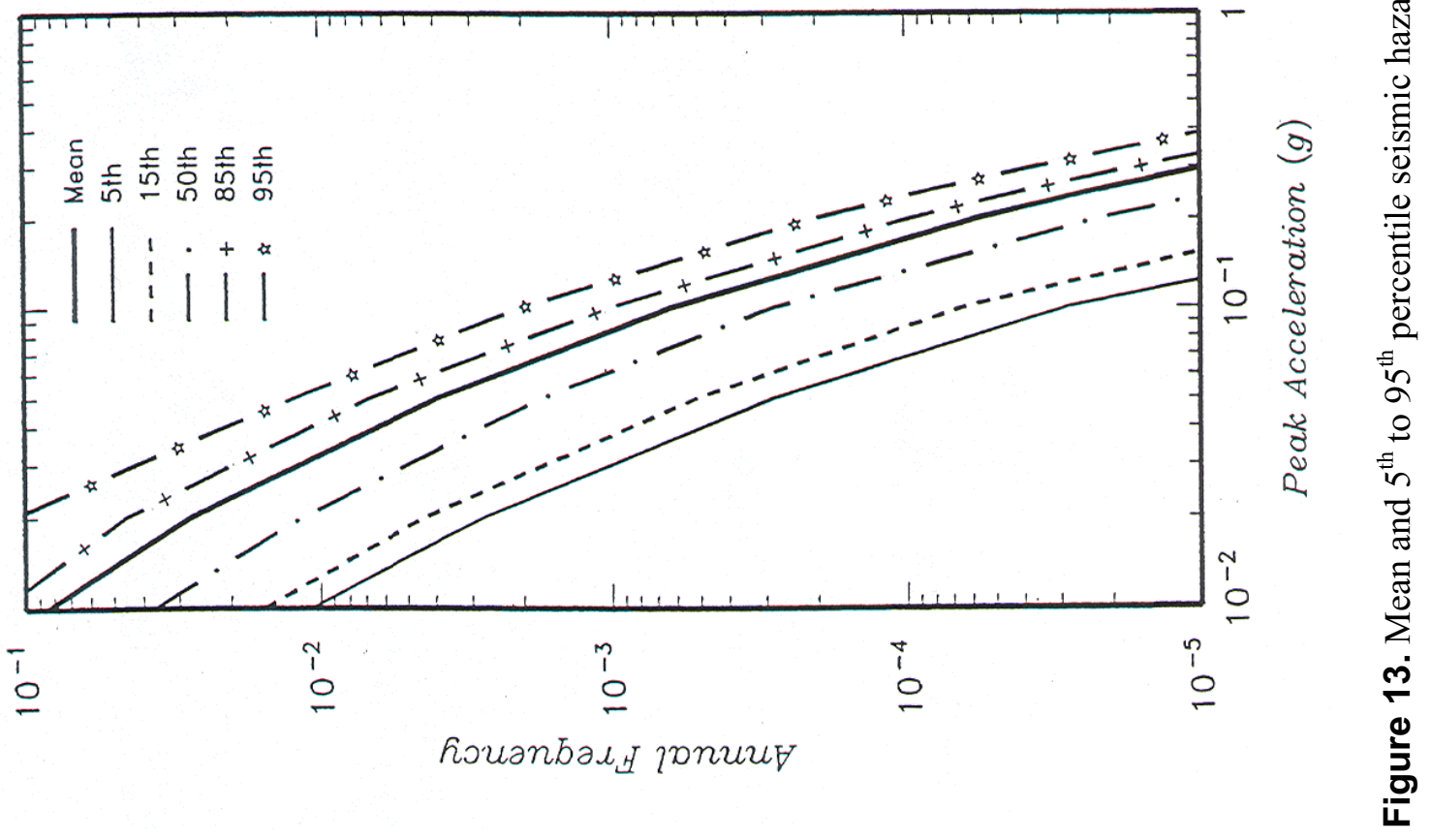




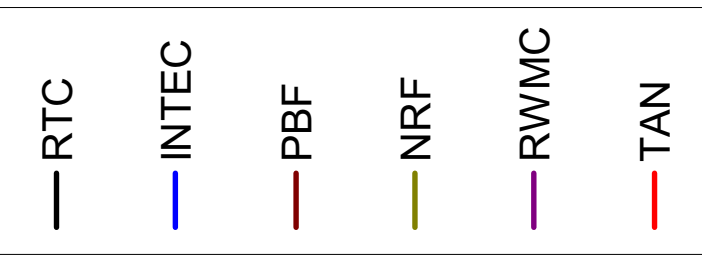

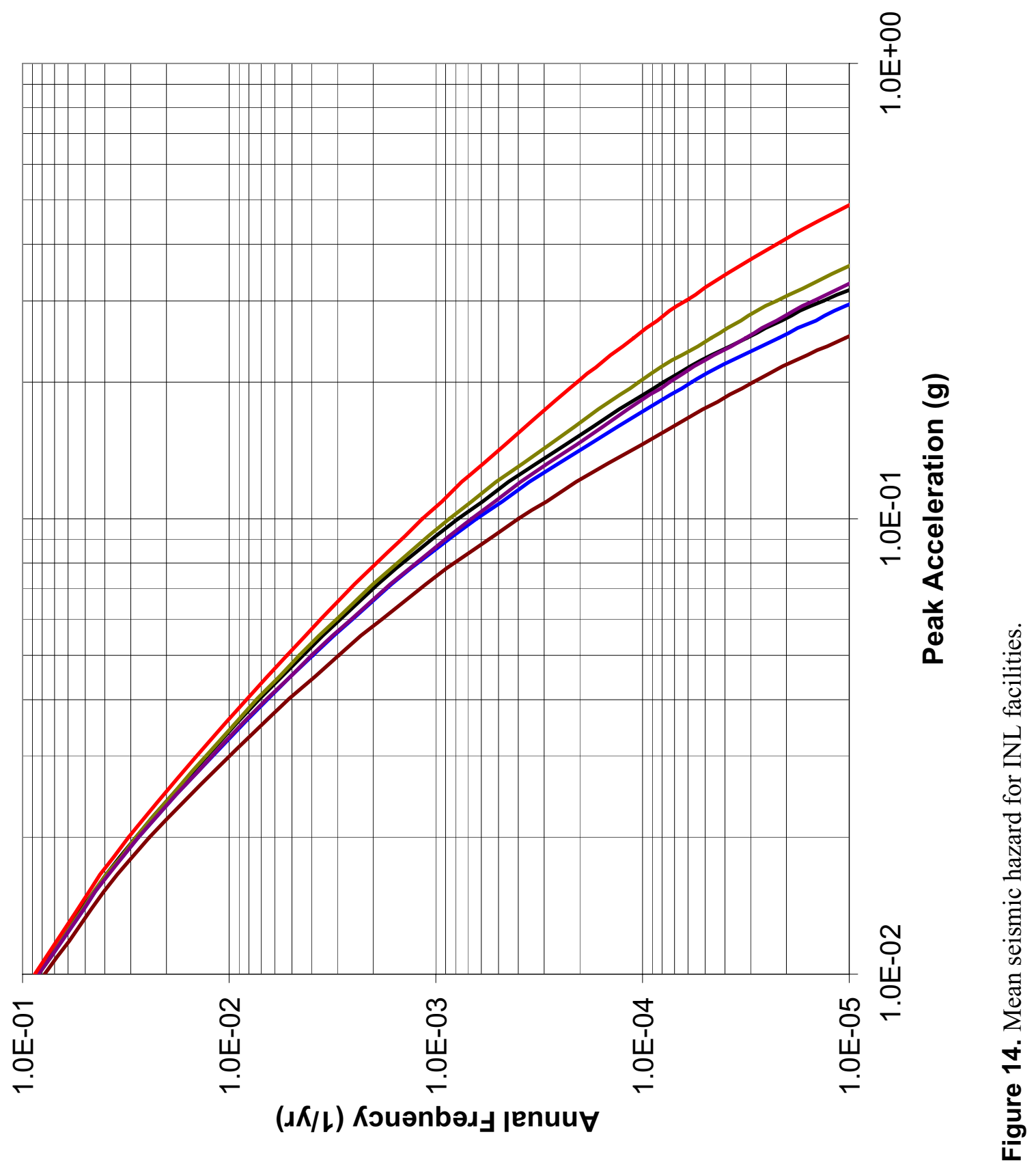




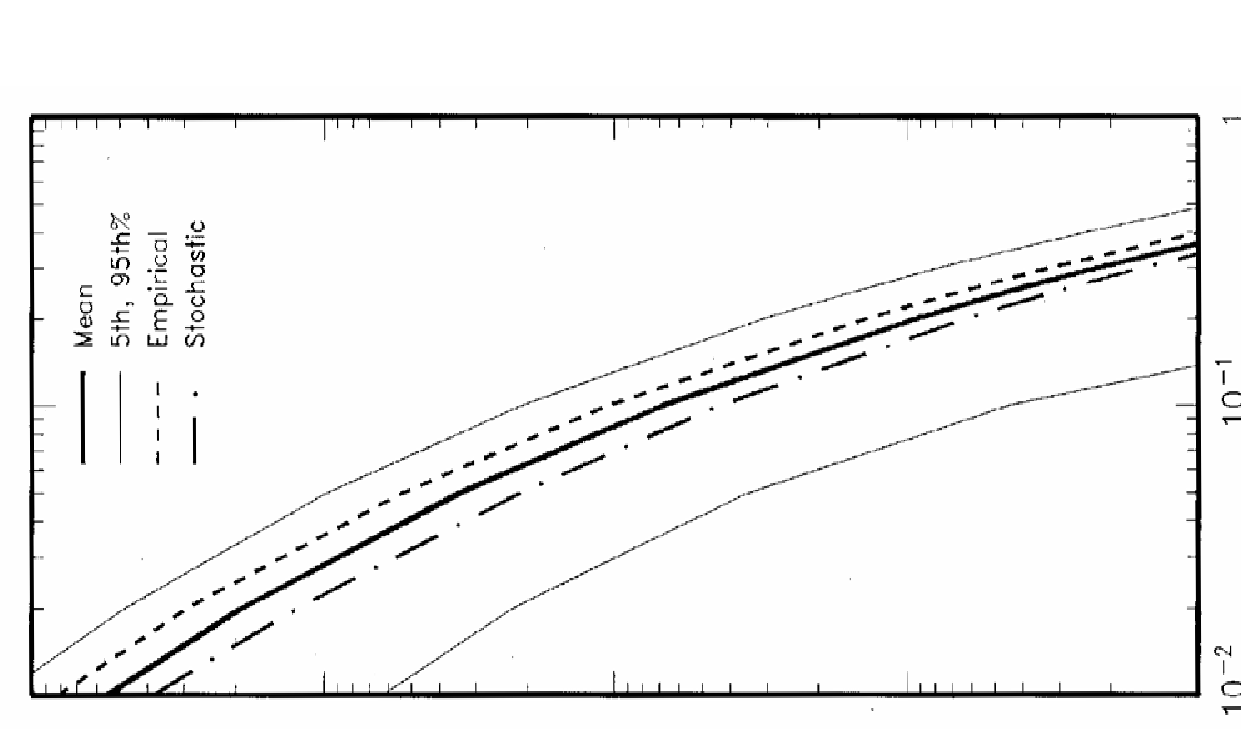

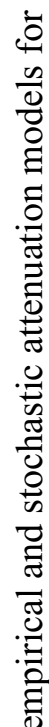

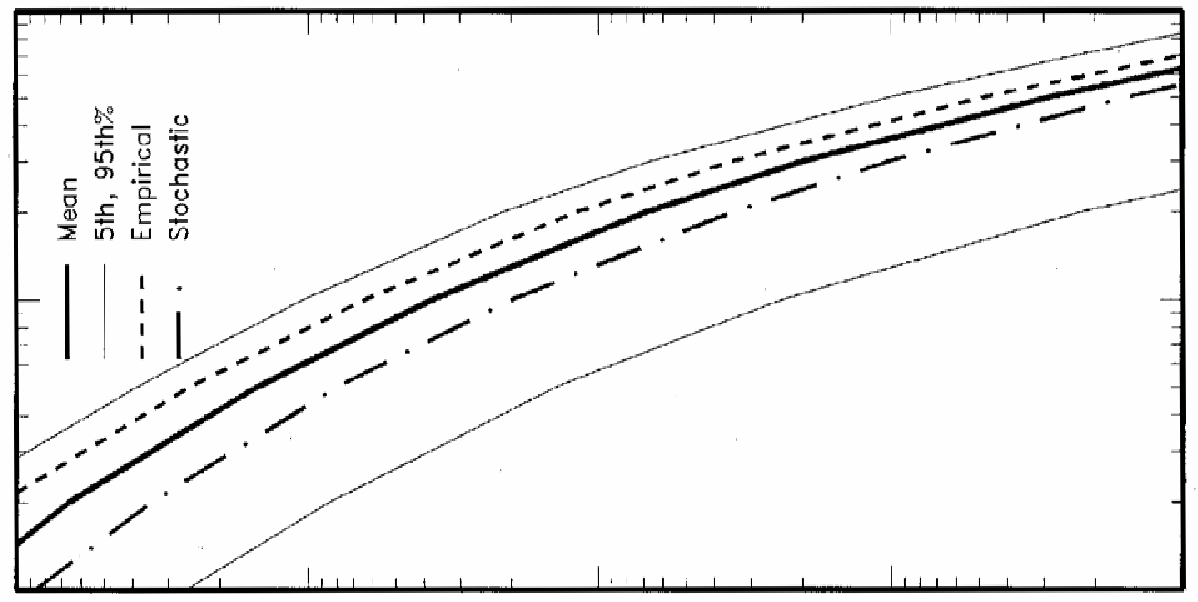

1

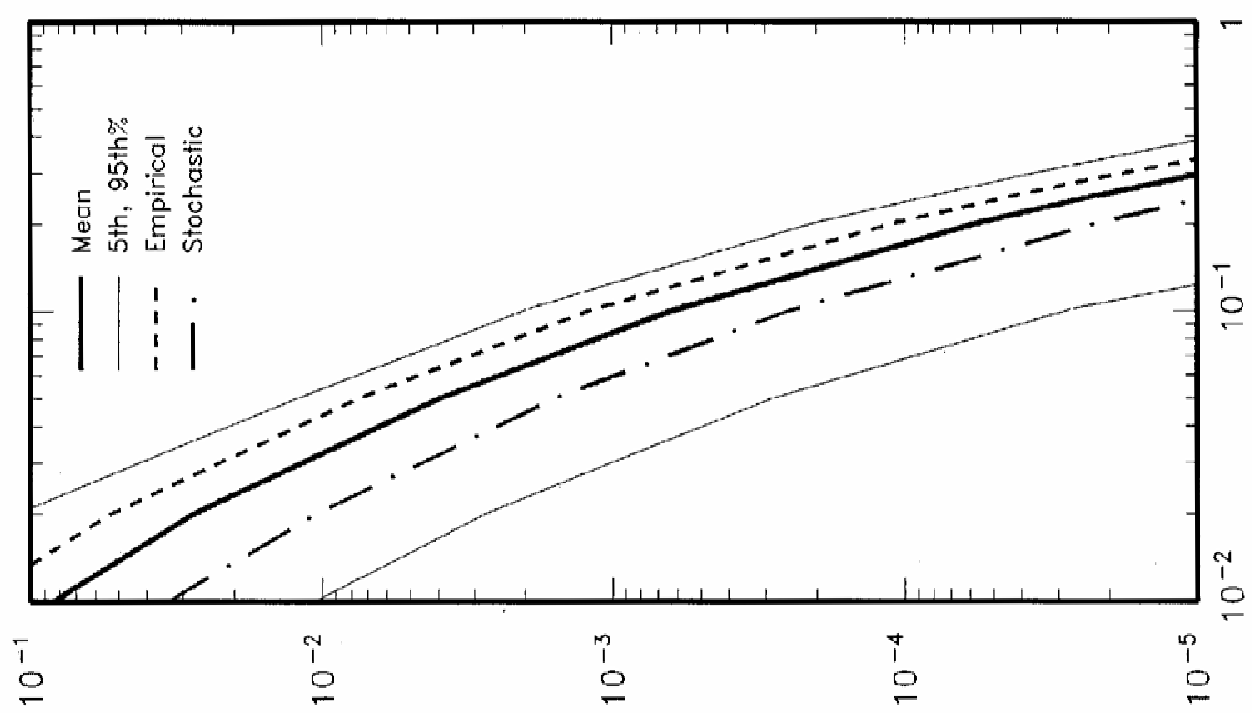

Кouanbart 7onuนt 


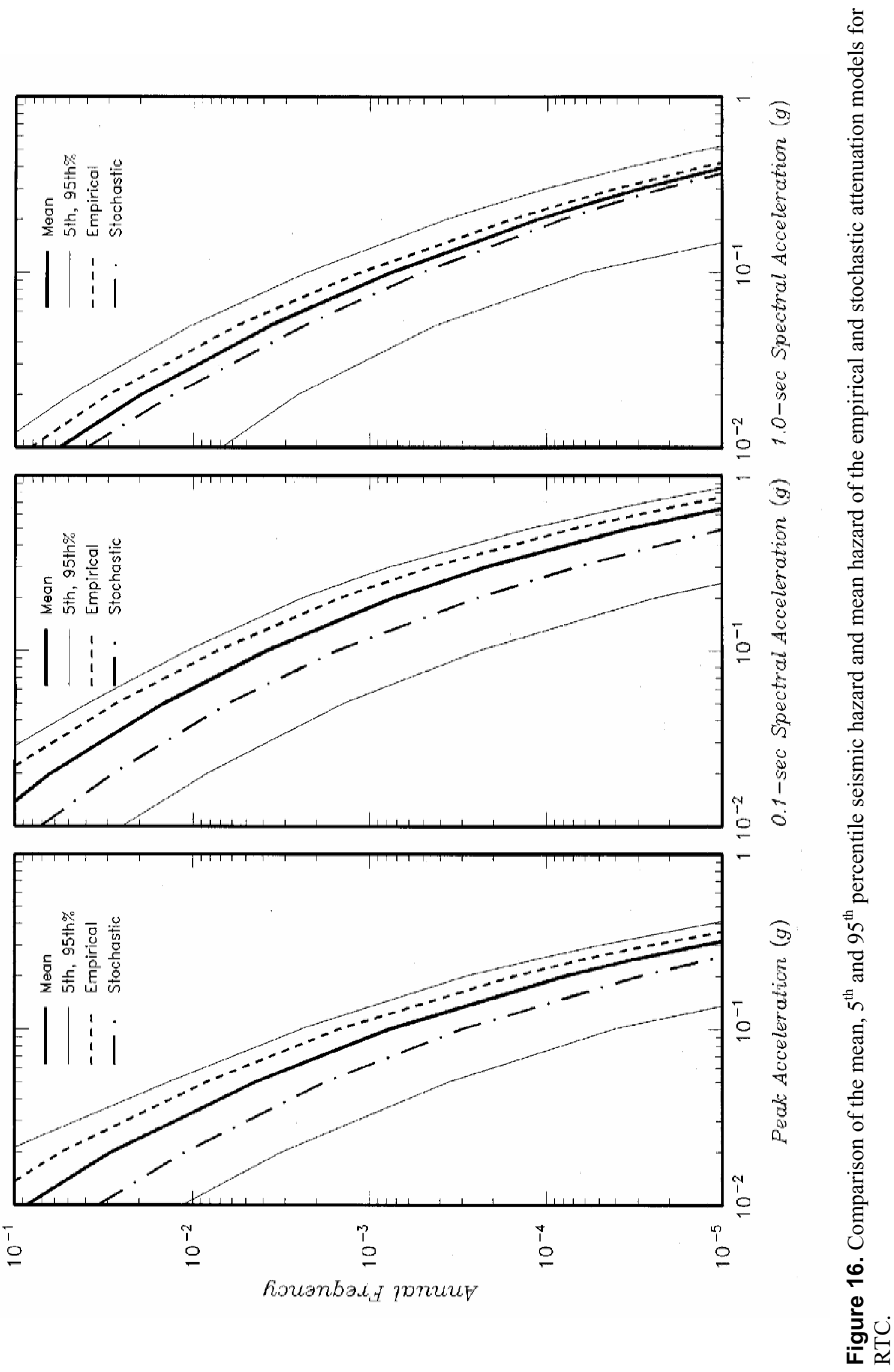

$\pi$ 


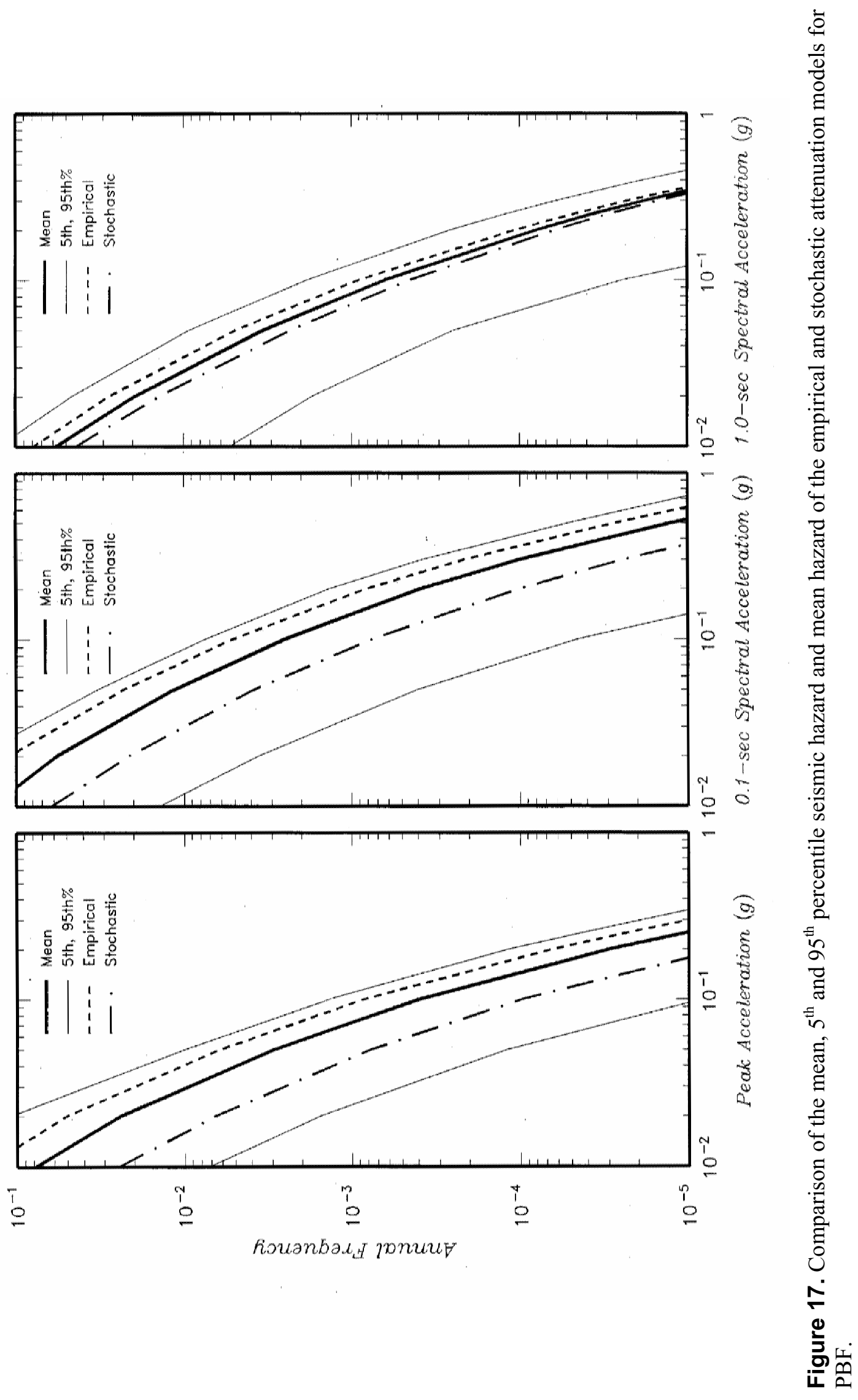




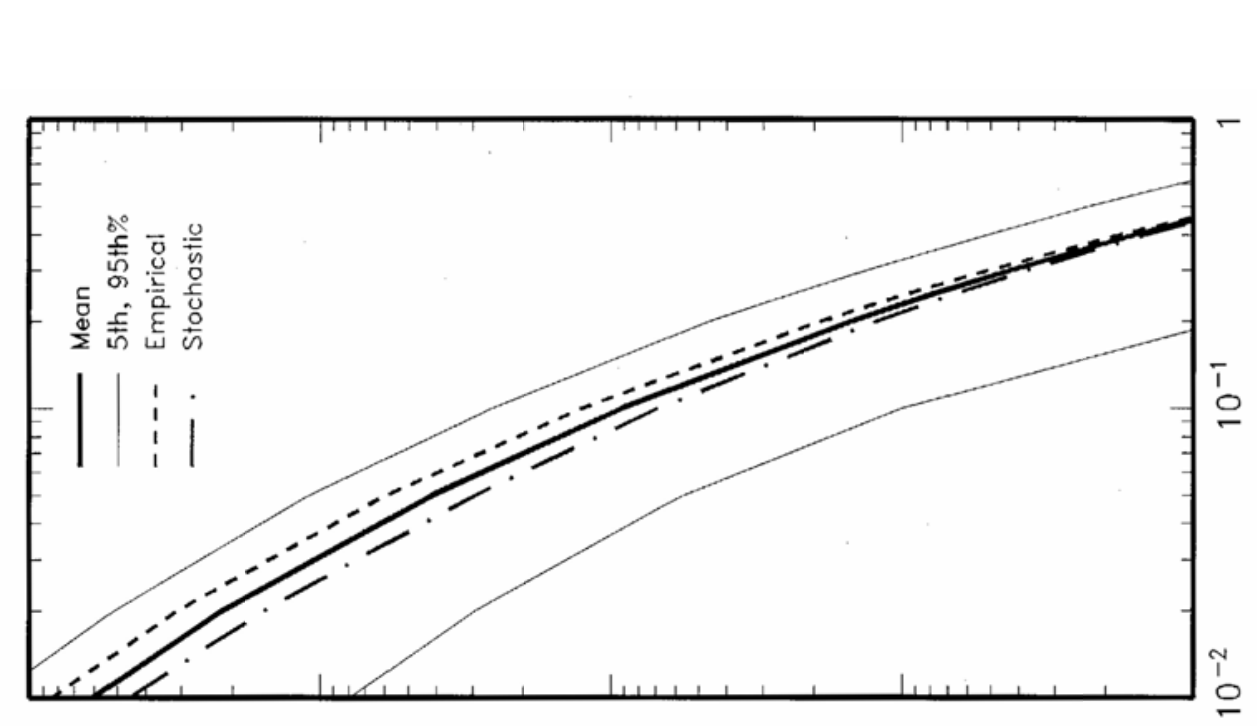

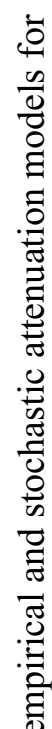

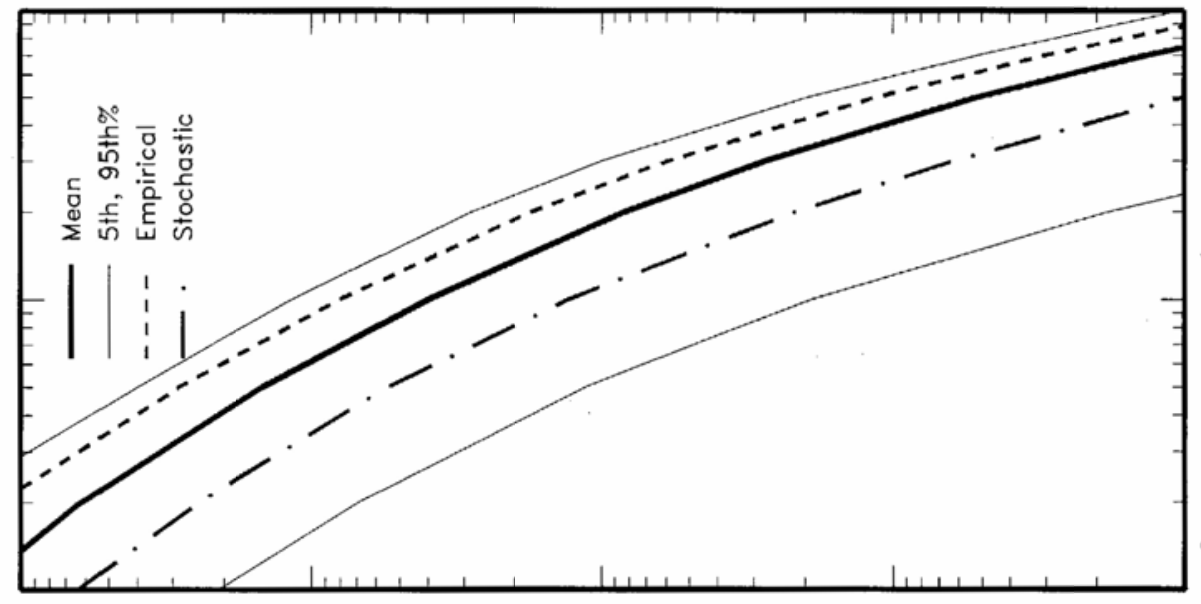

1

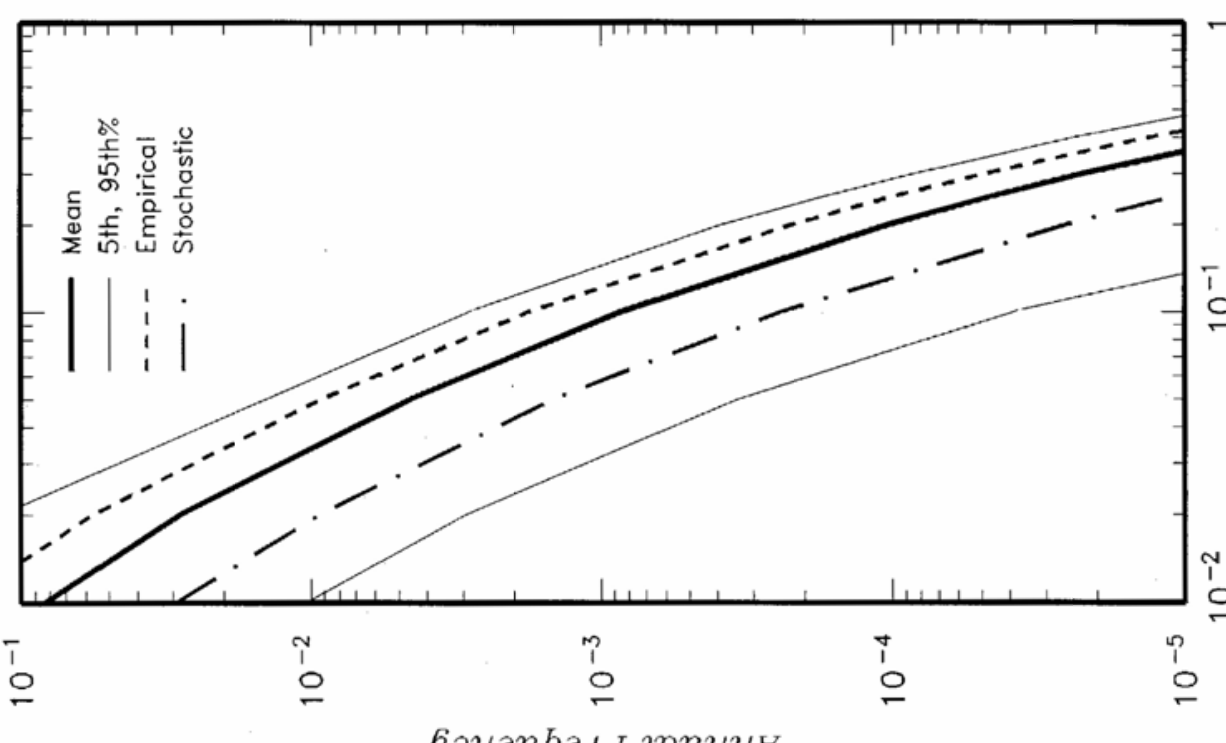

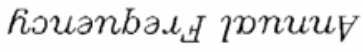

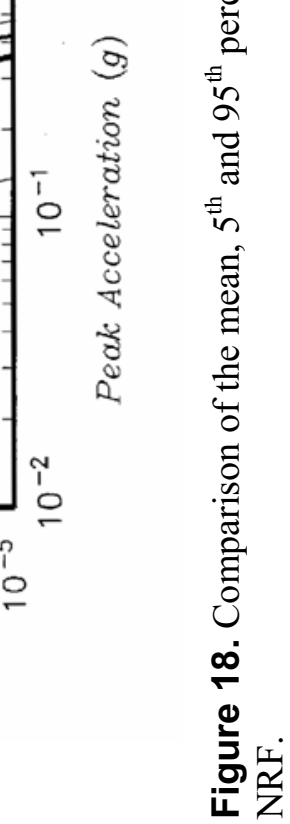



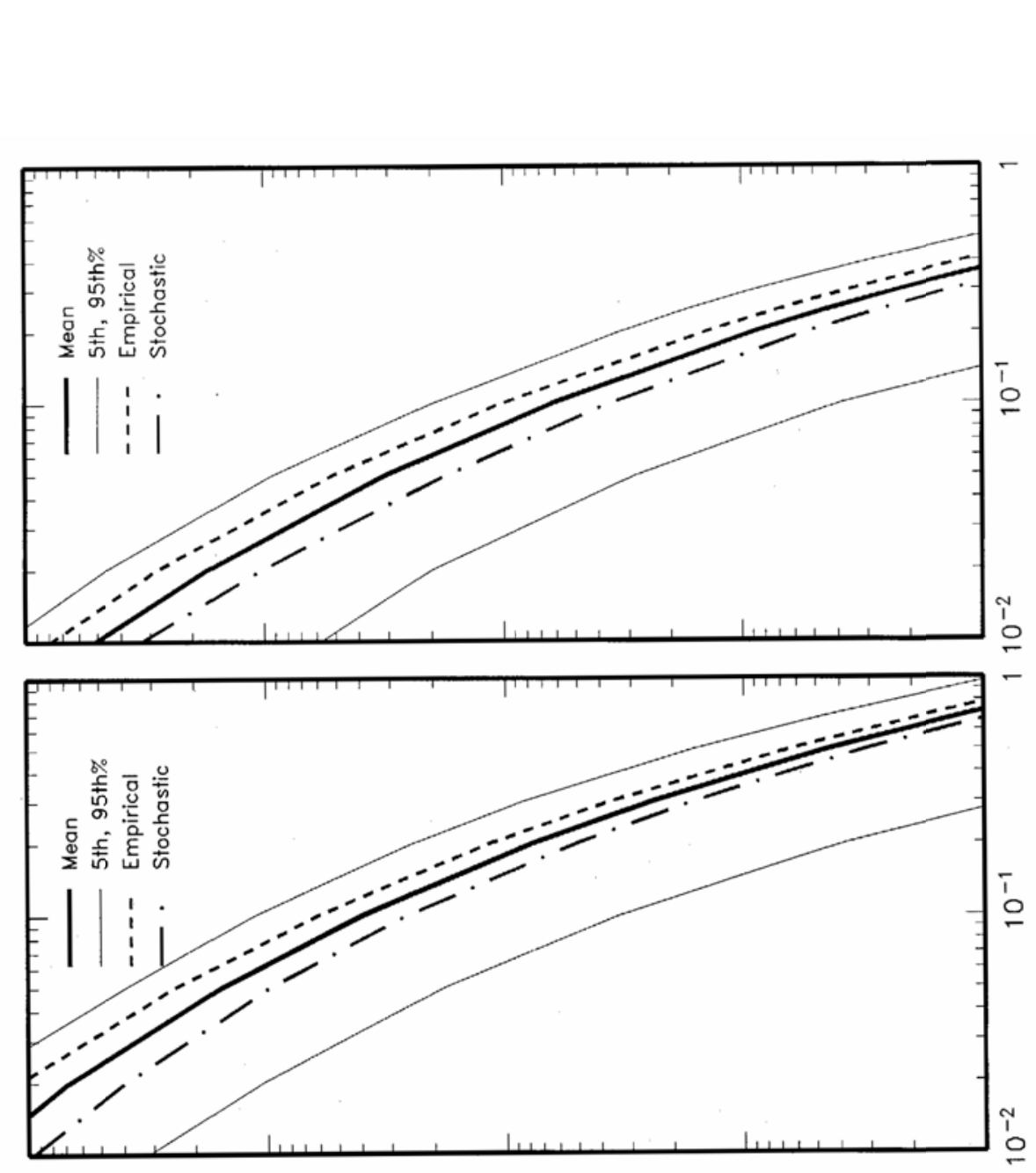

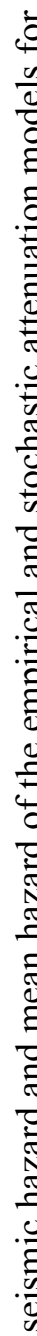

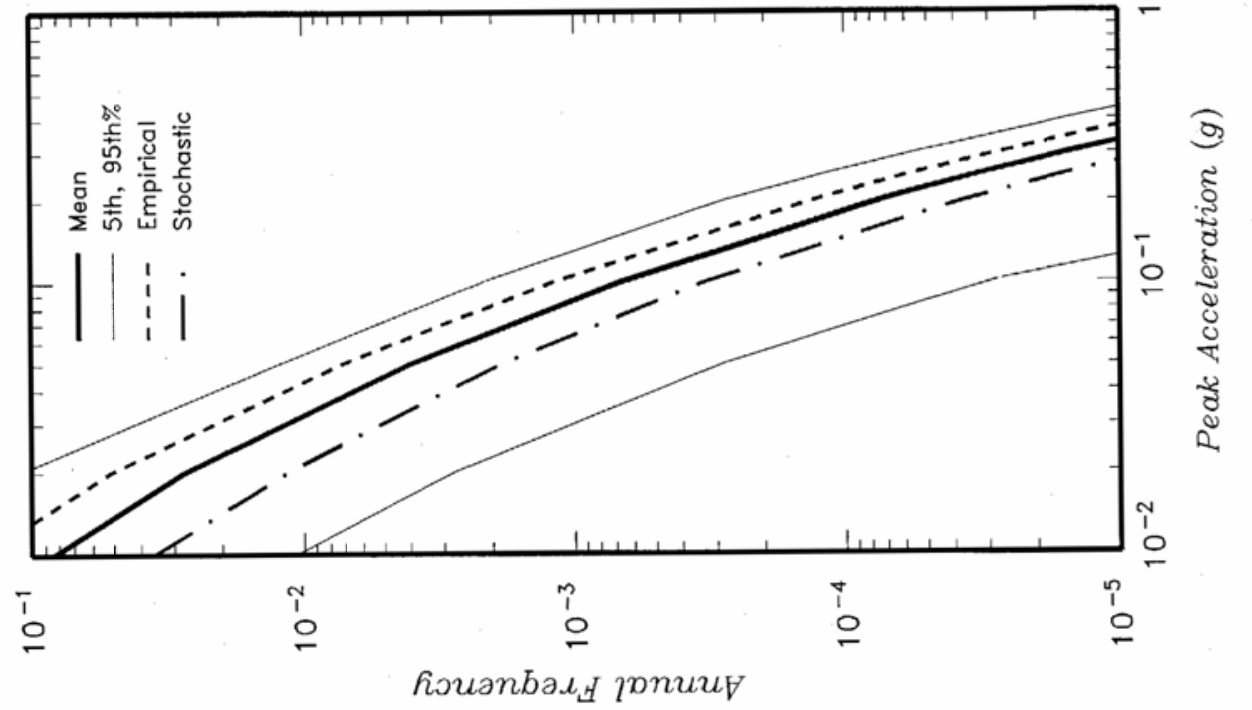

m 


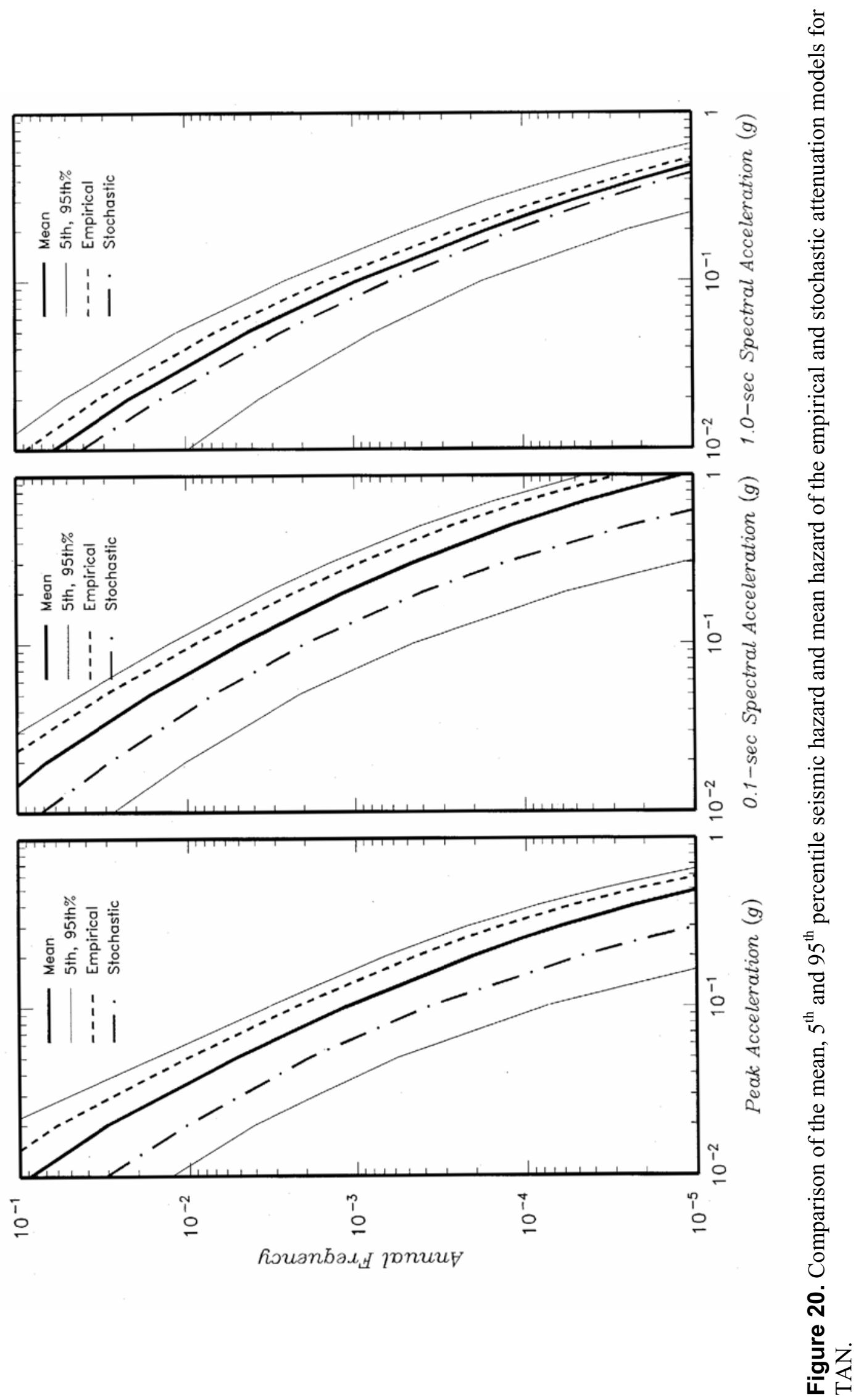




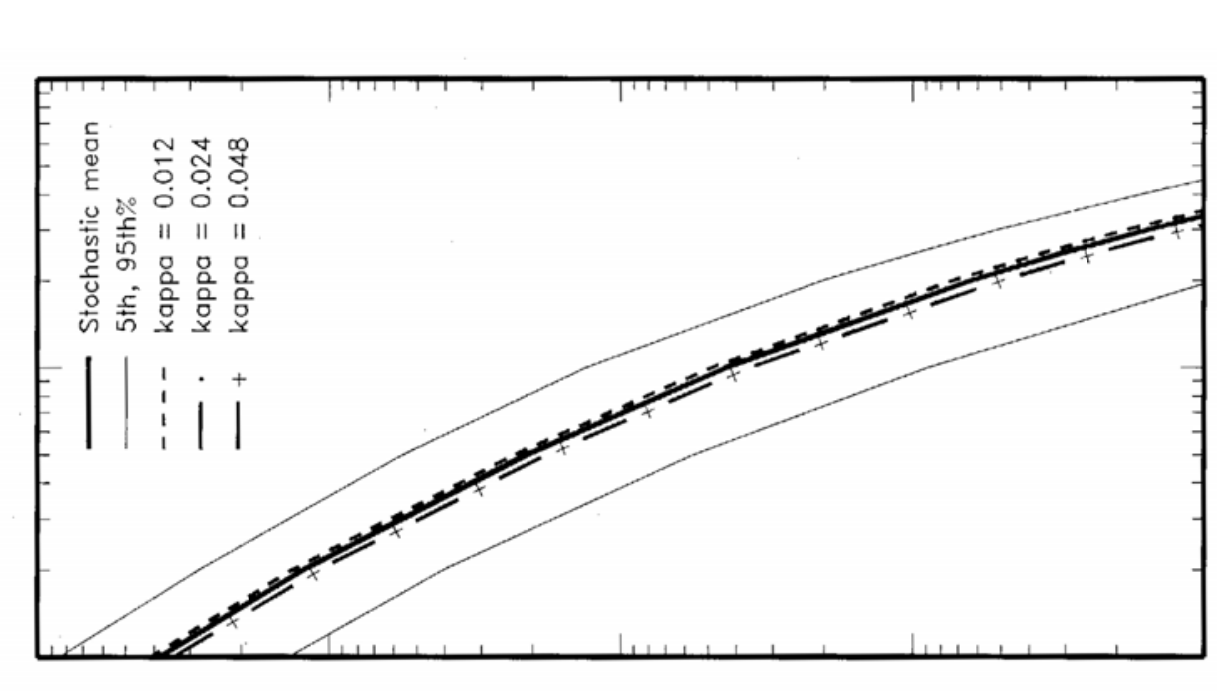

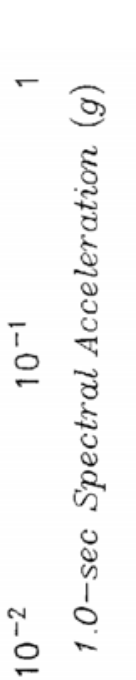

0
0
0
0
0
0
0
0
0
0
0
0
0
0
0
0
0
0
0
0
0
0
0
0
0
0
0

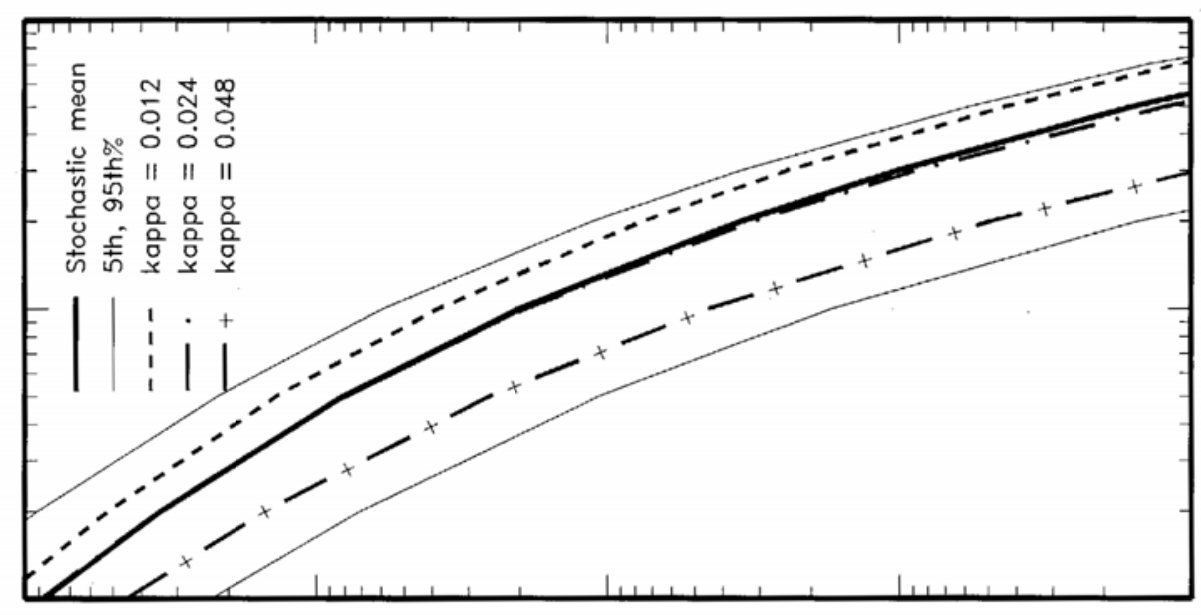

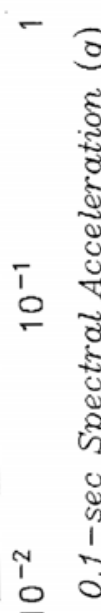

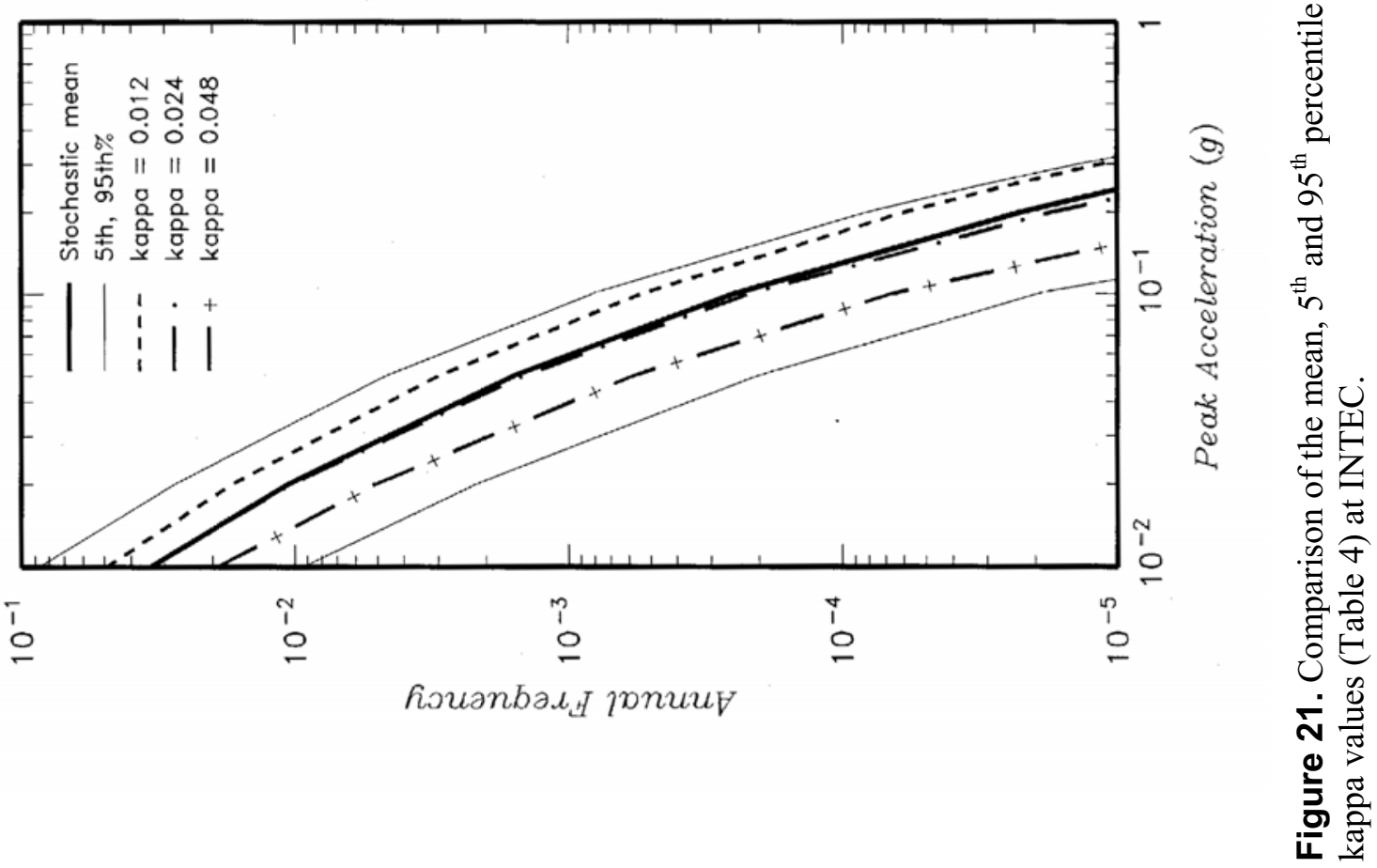

n 


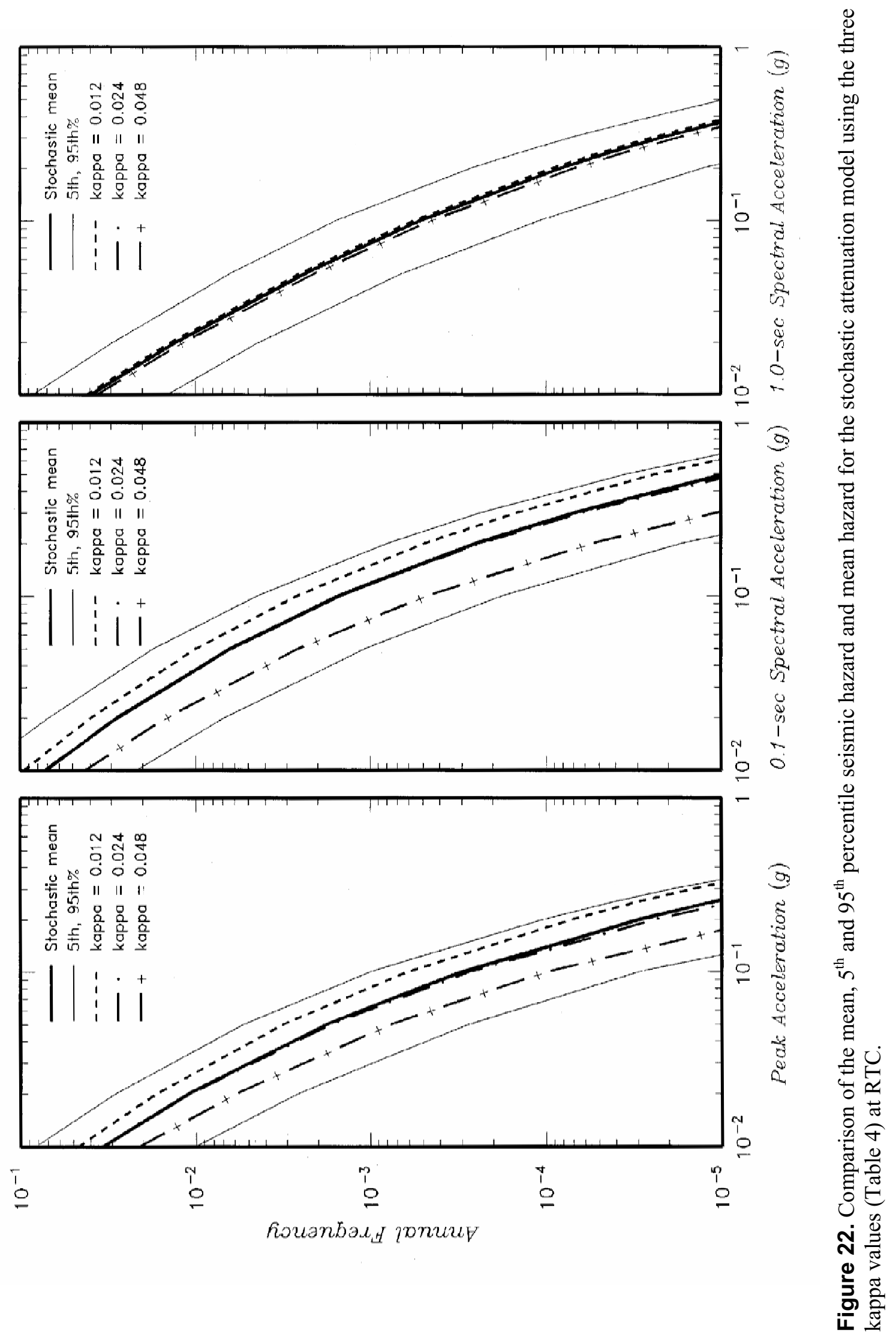




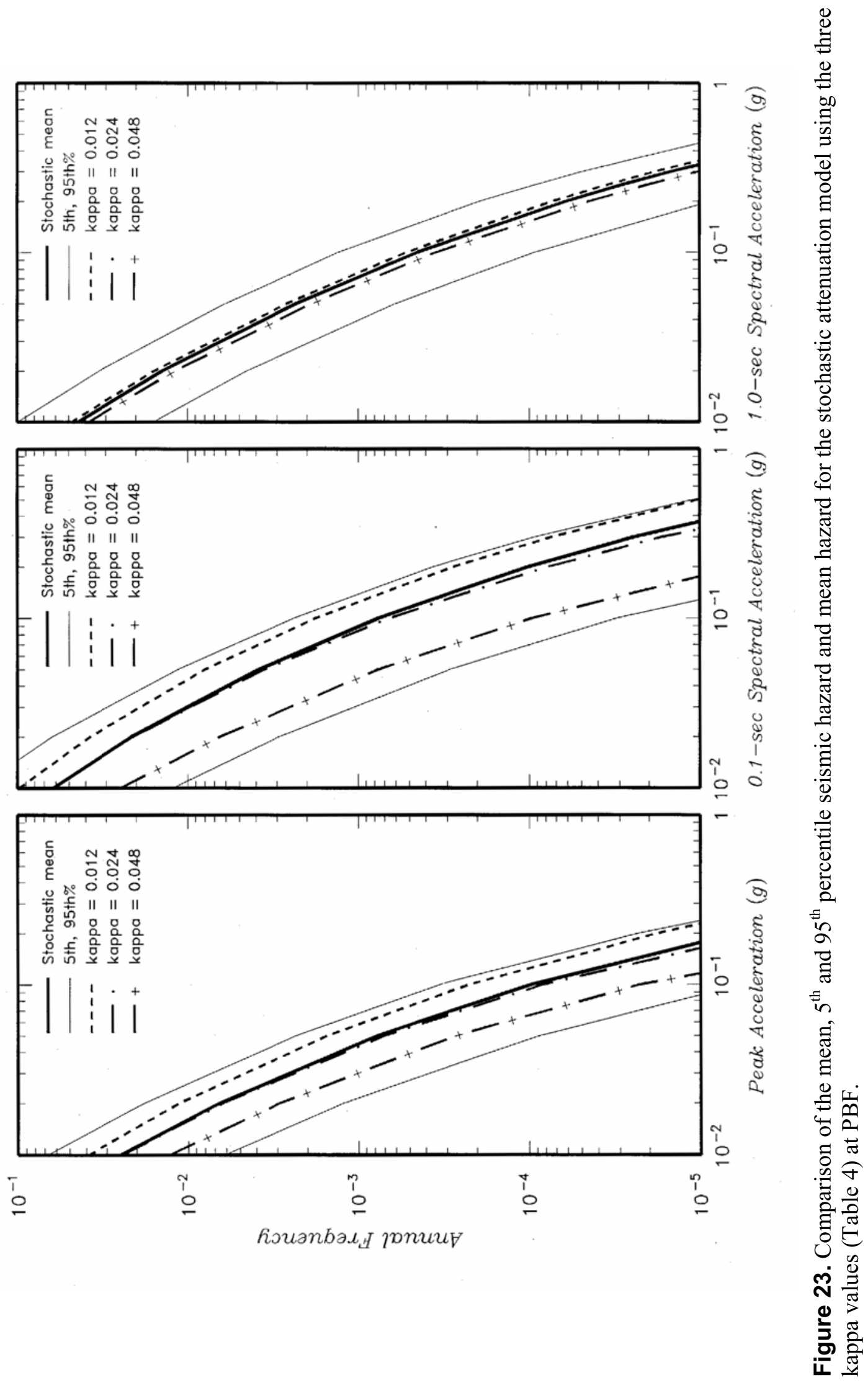




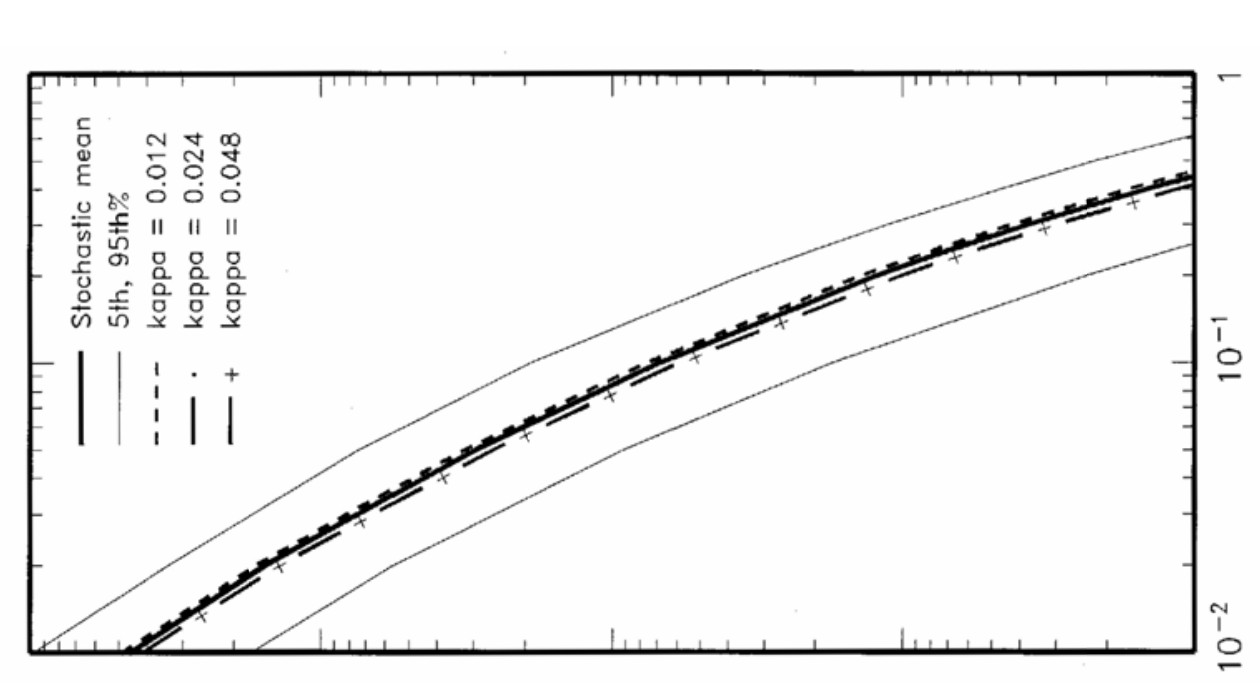

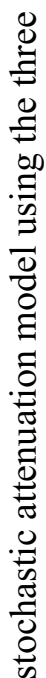

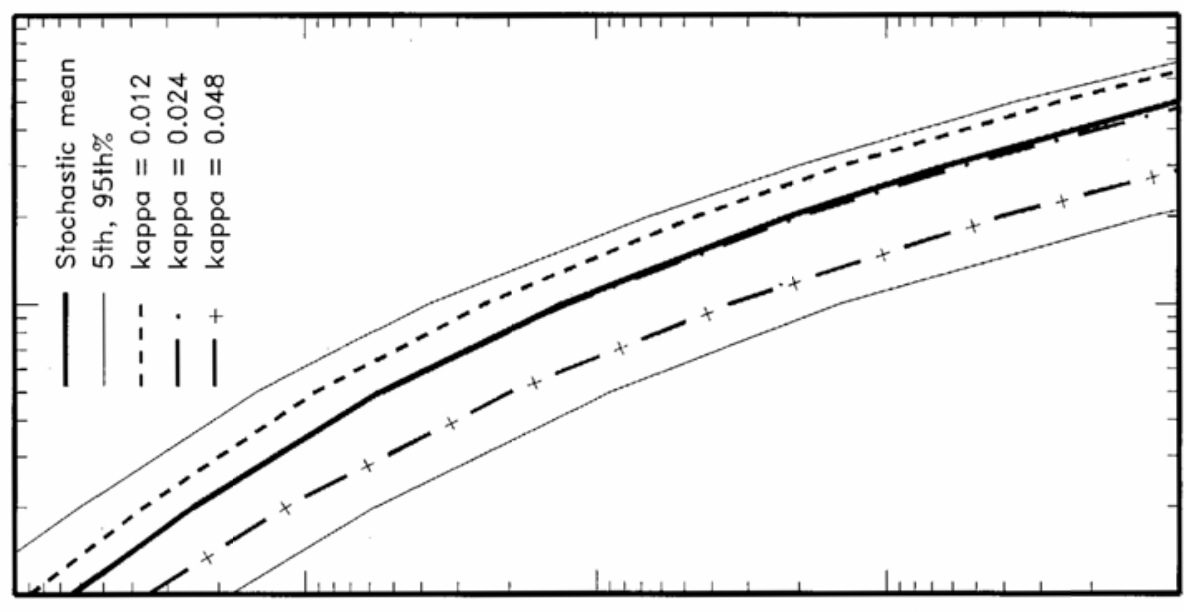

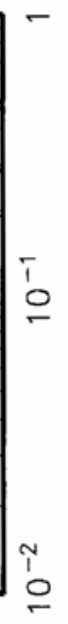
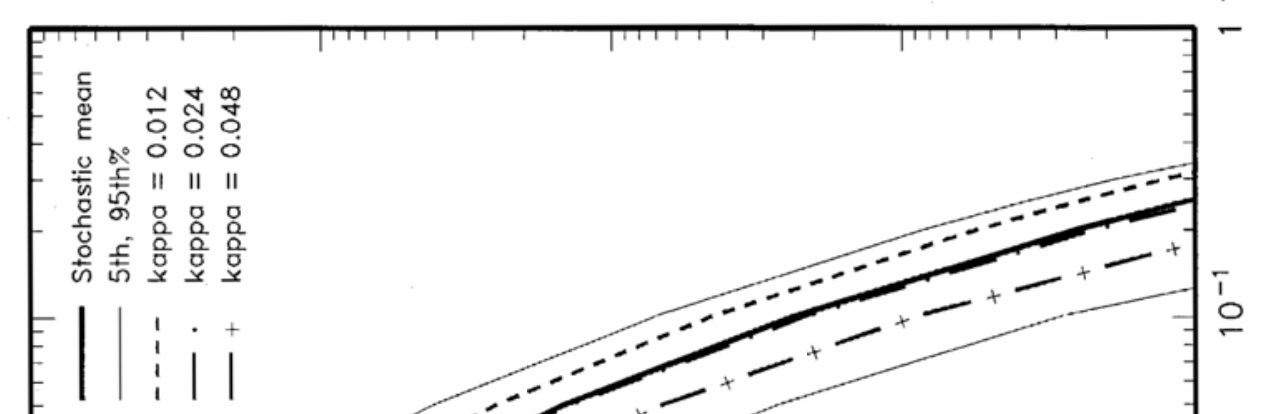

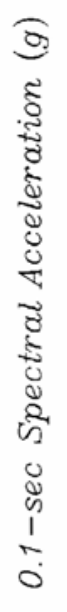




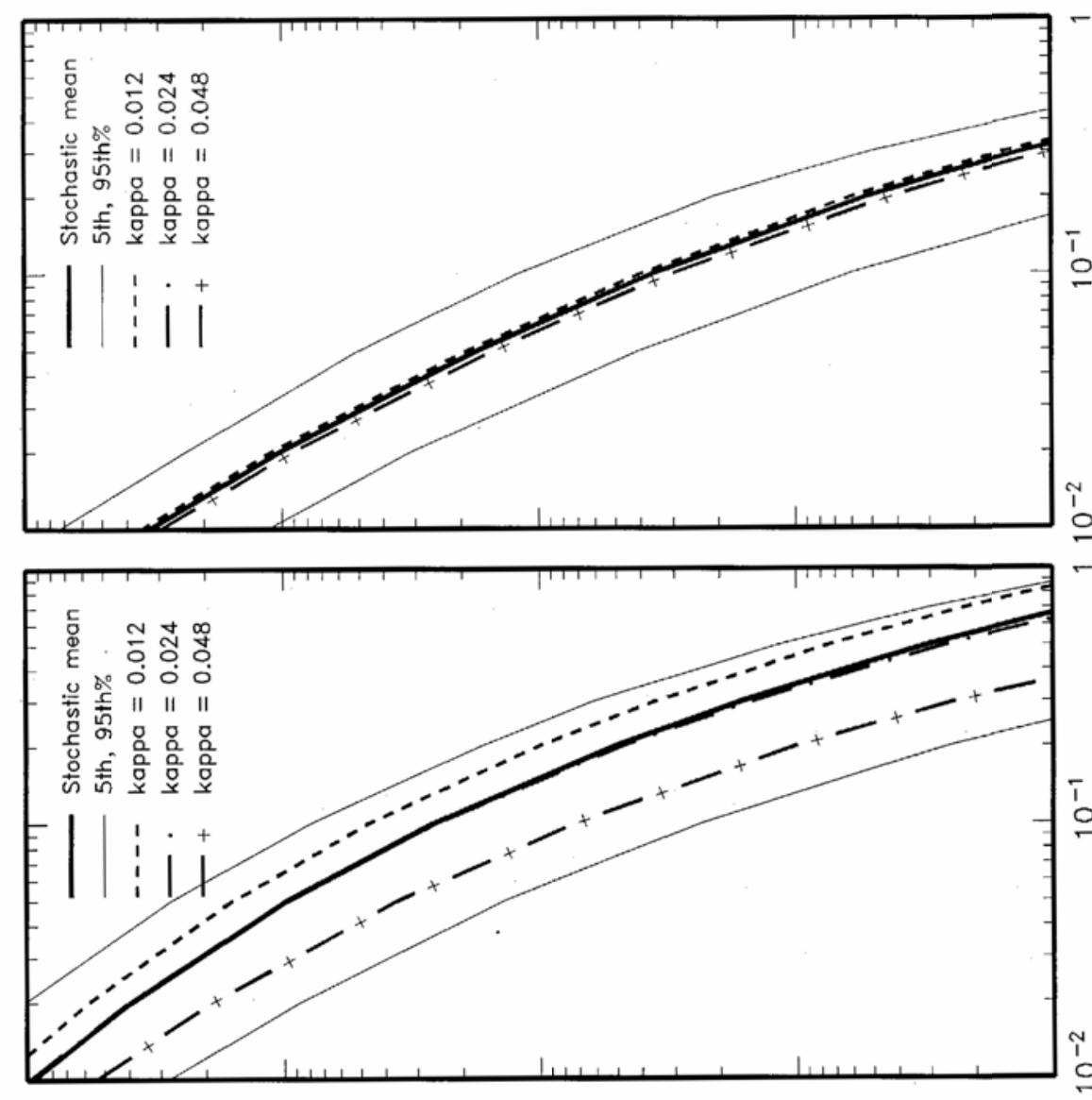

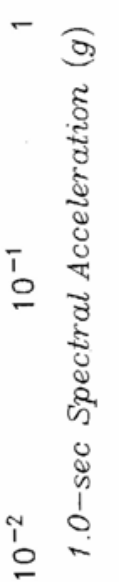

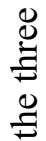

ํ.

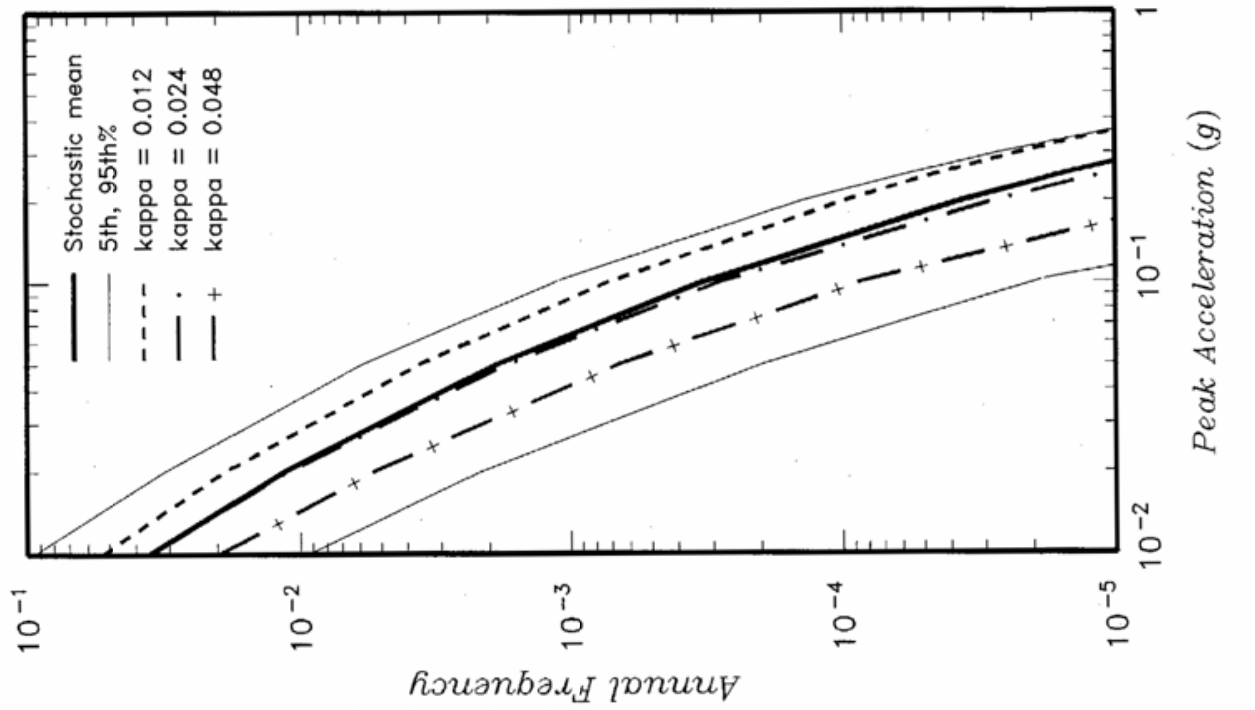




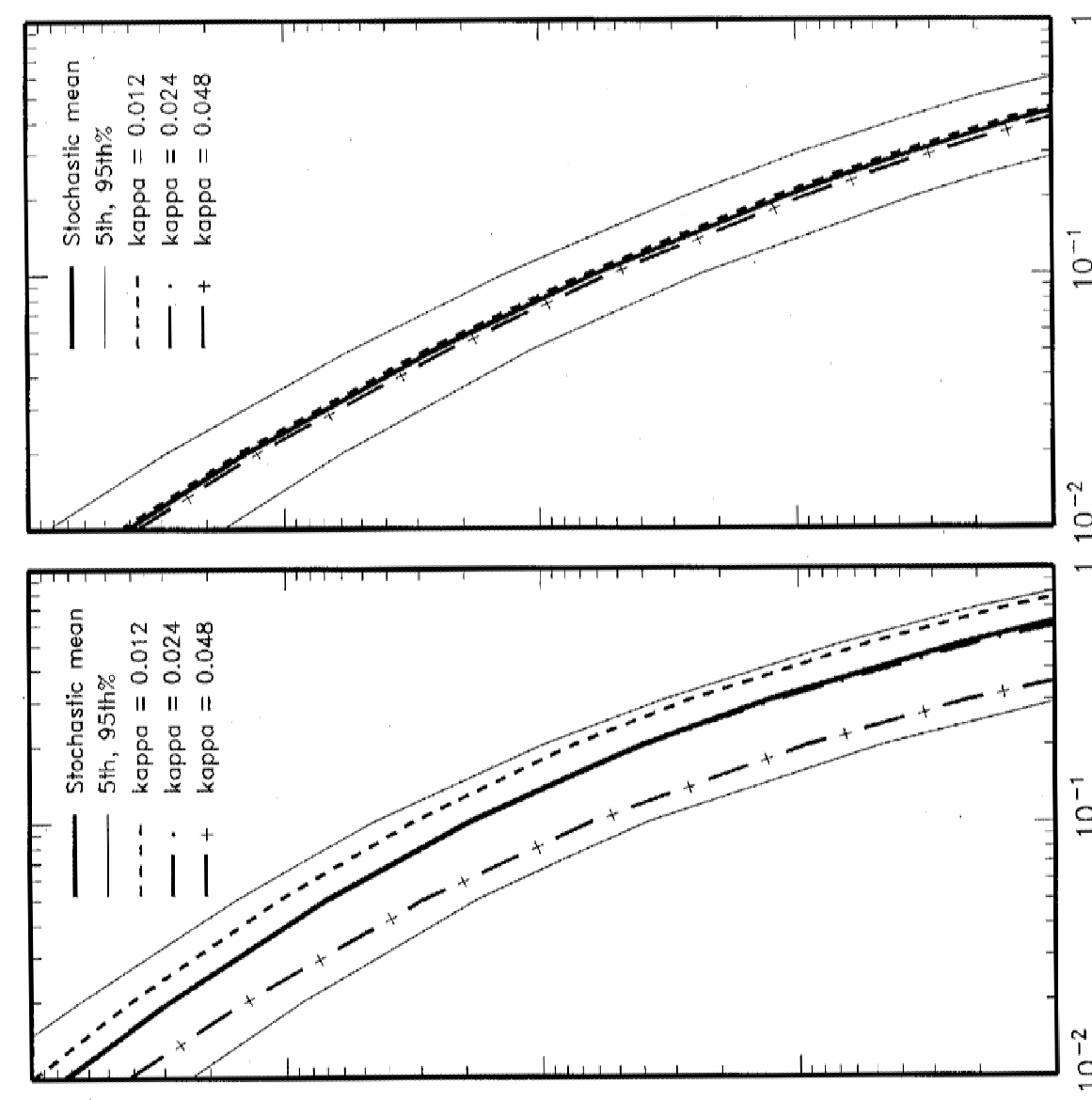

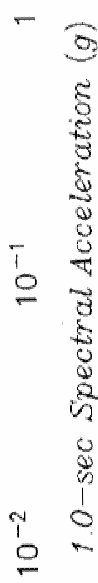

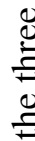

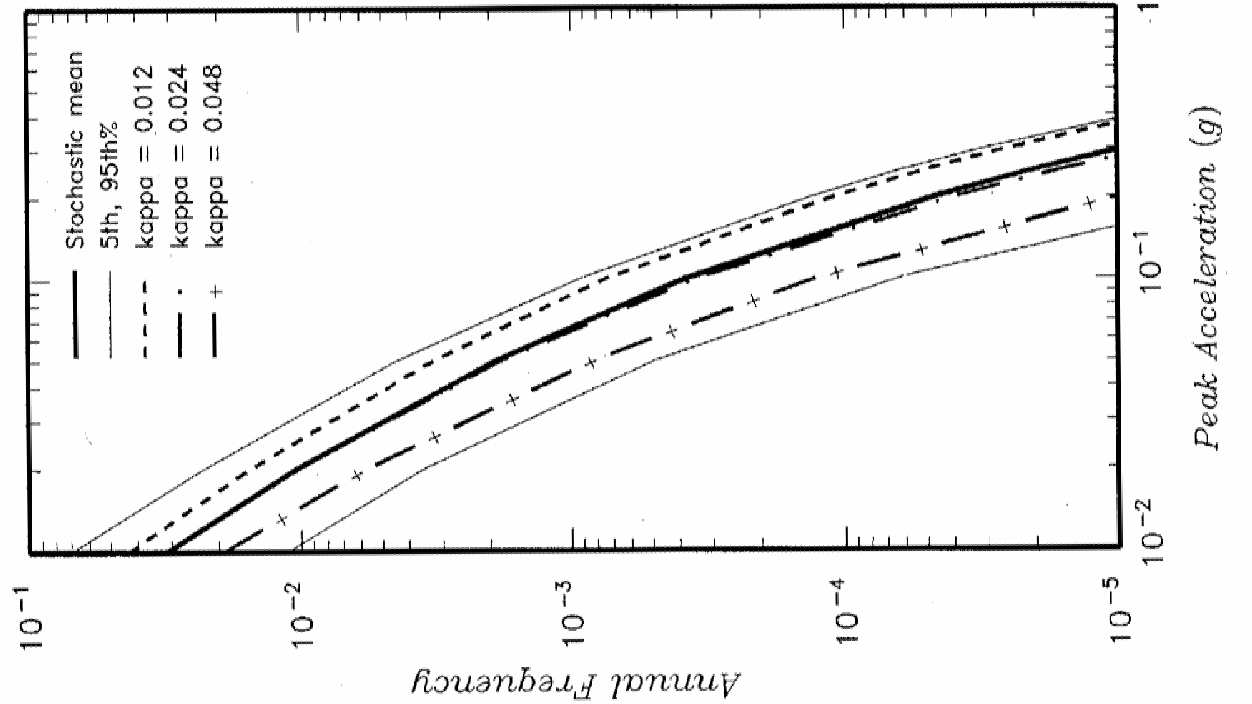



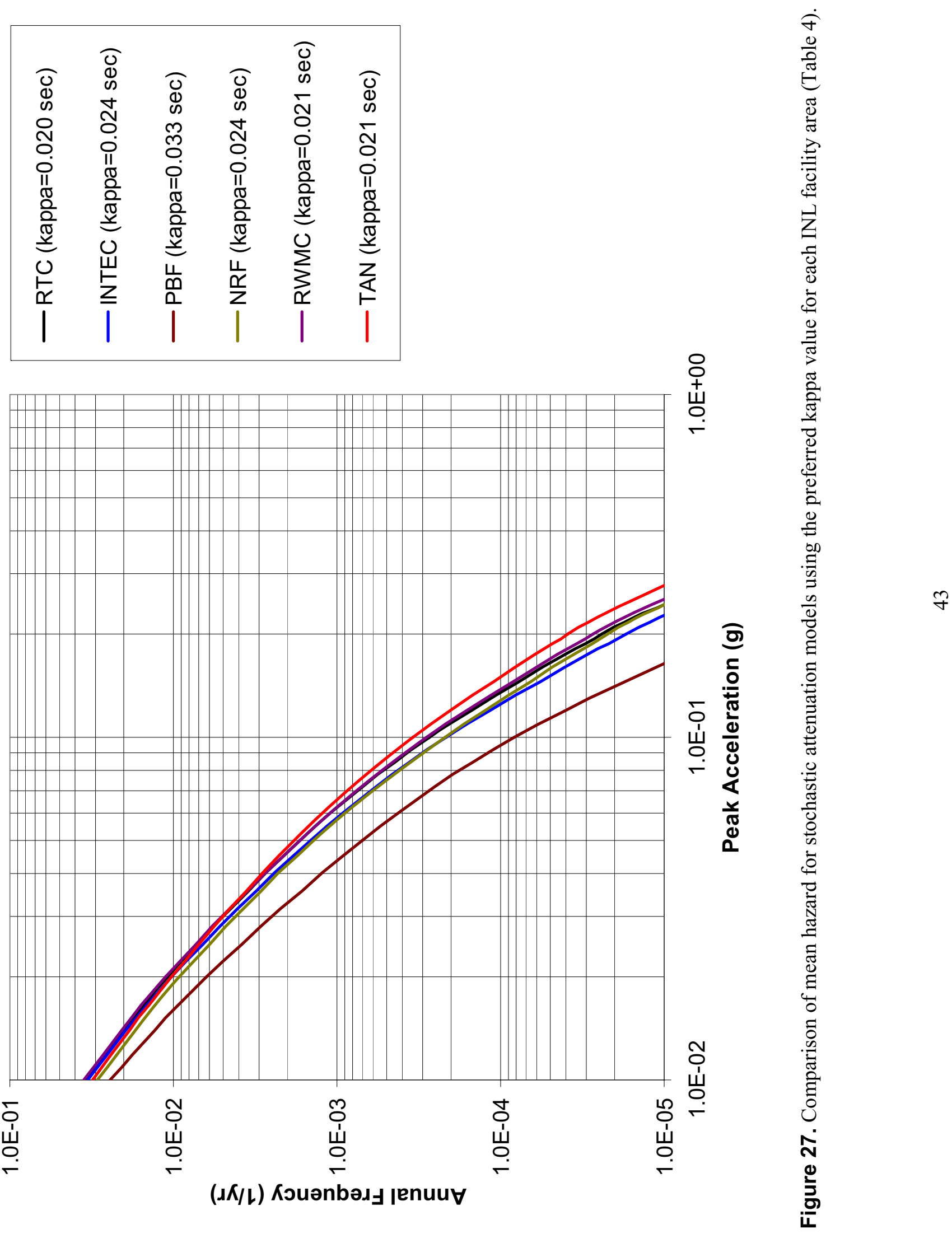


\section{Conclusions}

To estimate the probabilistic seismic hazard at INL facility areas, both empirical and site-specific stochastic attenuation relationships were used. The preferred approach in predicting ground motions at a site is through the use of attenuation relationships based on strong motion data recorded at that site. However, the lack of strong motion data for the ESRP to incorporate empirically derived site-specific attenuation relationships requires an alternative approach. The approach used at INL is one that models the source, path, and site properties in the ESRP and attempts to capture the epistemic uncertainties inherent in such properties.

The use of empirical attenuation relationships in these analyses from other extensional tectonic environments similar to the ESRP and surrounding Basin and Range provide a means to specifically incorporate the uncertainties in source and path effects. Developing site-specific attenuation relationships using a well-validated stochastic numerical ground motion model that incorporated the effects of the sedimentary interbedded basalt stratigraphy captured the epistemic uncertainties in site properties. These properties include the site-specific S-wave velocity profiles and the near-surface attenuation (kappa). Also, multiple stochastic attenuation relationships were computed using input parameters (such as kappa, $\mathrm{Q}$, stress drop, etc.) that have a range of values bounded by site-specific data.

Although the analyses performed for INL date back to 1996, the approach taken for INL still represents the state-of-the-art and is currently being used at other DOE sites such as the Los Alamos National Laboratory. The PSHA methodology is consistent with current DOE Standards (DOE 2002) and the Nuclear Regulatory Commission (NRC) recommendations in NUREG/CR-6728 (NRC 2001). Since the seismic hazard re-computation in 2000 , no new data have been collected that would invalidate the results of the PSHA estimates, which form the basis for current rock design basis earthquake (DBE) levels at each INL facility area. 


\section{References}

Abrahamson, N. A. and W. J. Silva (1997), Empirical response spectral attenuation relations for shallow crustal earthquakes, Seismological Research Letters, v. 68, p. 94-127.

Agbabian Associates Inc. (1995), Borehole velocity and damping measurements at Argonne National Laboratory West Borehole ANL-1; Report \#9455-6554 prepared for ANL-W under contract 31109-38-9410-W, Pasadena, California, 39 p.

Anderson, J. G. and S. E. Hough (1984), A model for the shape of the Fourier amplitude spectrum of acceleration at high frequencies, Bulletin of the Seismological Society of America, v. 74, p. 19691994.

Armstrong, R. L., W. P. Leeman, and H. E. Malde (1975), Quaternary and Neogene volcanic rocks of the Snake River Plain, Idaho, American Journal of Science, v. 275, p. 225-251.

Atkinson, G. M. (1984), Attenuation of strong ground motion in Canada, Bulletin of the Seismological Society of America, v. 74, p. 2629-2953.

Boore, D.M. (1983), Stochastic simulation of high-frequency ground motions based on seismological models of the radiated spectra, Bulletin of Seismological Society of America, v. 73, p. 1865-1884.

Boore, D.M. (1986), Short period P- and S-wave radiation from large earthquakes: Implications for spectral scaling relations, Bulletin of Seismological Society of America, v. 76, p. 43-64.

Boore, D. M., W. B. Joyner, and T. E. Fumal (1997), Equations for estimating horizontal response spectra and peak accelerations from western North American earthquakes, A summary of recent work, Seismological Research Letters, v. 68, p. 128-153.

Bratt, S.R. and Purdy, C.M. (1984), Structure and variability of oceanic crust on the flanks of the EPR, Journal of Geophysical Research, v. 89, p. 6111-6125.

Brott, C. A., D. D. Blackwell, and J. P. Ziagos (1981), Thermal and tectonic implications of heat flow in the eastern Snake River Plain, Idaho, Journal of Geophysical Research, v. 86, p.11709-11734.

Brune, J. N. (1970), Tectonic stress and the spectra of seismic shear waves form earthquakes, Journal Geophysical Research, v. 75, p. 4997-5009.

Brune, J. N. (1971), Correction, Journal Geophysical Research, v. 76, p. 5002.

Campbell, K. W. (1997), Empirical near-source attenuation relationships for horizontal and vertical components of peak ground acceleration, peak ground velocity, and pseudo- absolute acceleration response spectra, Seismological Research Letters, v. 68, p. 154-179.

Cornell, C. A. (1968), Engineering seismic risk analysis, Bulletin of the Seismological Society of America, v. 58, p. 1583-1606.

Crawford, W. C, S. C. Webb, and J. A. Hildebrand (1993), Shear velocity structure of the Juan de Fuca Ridge from seafloor compliance measurements, EOS, Transactions, American Geophysical Union, v. 74, p. 604. 
DeVan, R. and J. W. Martin (1989), Dynamic Mechanical Properties Well 2-2A and Well INEl-1, Terra Tek Inc., report TR-90-20 submitted to EG\&G Idaho Inc., August.

Dobrin, M.B. (1952) Introduction to Geophysical Prospecting, McGraw-Hill, N.Y., p. 460.

DOE (2002), Natural Phenomena Hazards Assessment Criteria, U.S. Department of Energy, DOE Standard, DOE-STD-1023-2002.

Doherty, D.J. (1979a), Drilling data from exploration well 1, NE 1/4, sec.22, T.2N., R. 32E., Bingham County, Idaho, U.S. Geological Survey Open-File Report 79-1225, 1 sheet.

Doherty, D.J. (1979b), Drilling data from exploration well 2-2A, NW 1/4, Sec. 15, T5N, R31E, Idaho National Engineering Laboratory, Butte County, Idaho, U.S. Geological Survey Open-File Report 79-851, 1 sheet.

Doherty, D.J., L.A. Morgan, and M.A. Kuntz (1979), Preliminary geologic interpretation and lithologic $\log$ of the exploratory geothermal test well (INEL-1), Idaho National Engineering Laboratory, eastern Snake River Plain, Idaho, U.S. Geological Survey Open-File Report 79-1248, 10 p.

Faust, L.Y. (1951), Seismic velocity as a function of depth and geologic time, Geophysics, v. 16, p. 192206.

Francis, T. J, and G. G. Shor Jr., (1966), Seismic refraction measurements in the northwest Indian Ocean, Journal of Geophysical Research, v. 71, p. 427-449.

Filipkowski, F., M. Blackey, D. Davies, E.N. Levine, and V. Murphy (1991), Geophysical investigation New Production Reactor complex, INEL, EG\&G Idaho Inc. Informal Report EGG-NPR-10689, Appendix C.

Gardner, G.H.F., L. W. Gardner, and A. R. Gregory (1974), Formation velocity and density - The diagnostic basics for stratigraphic traps; Geophysics, v. 39, p. 770-780.

Hackett, W.R. and R. P. Smith (1992), Quaternary volcanism, tectonics, and sedimentation in the Idaho National Engineering Laboratory area in Wilson, J.R., editor, Field guide to geologic excursions in Utah and adjacent areas of Nevada, Idaho, and Wyoming, Geological Society of America Rocky Mountain Section Guidebook, Utah Geological Survey Miscellaneous Publication 92-3, p. 1-18.

Hanks, T. C. and H. Kanamori (1979), A moment magnitude scale, Journal Geophysical Research, v. 84, p. $2348-2350$.

Idriss, I. M. (1991), Earthquake ground motions at soft soil sites, Second International Conference on Recent Advances in Geotechnical Earthquake Engineering and Soil Dynamics, v. 3, p. 2265-2272.

Jarchow, C.M. and R. D. Catchings (1994), Large-explosive-source, wide-recording-aperture seismic profiling on the Columbia Plateau, Washington, Geophysics, v. 59, p. 259-271.

Keefer, D. I., and S. E. Bodily (1983), Three-point approximation for continuous random variables, Management Science, v. 26, p. 595-609. 
Kuntz, M. A., E. C. Spiker, M. Rubin, D. E. Champion, and R. H. Lefebvre (1986), Radiocarbon studies of latest Pleistocene and Holocene lava flows of the Snake River Plain, Idaho: Data, lessons, interpretations, Quaternary Research, v. 25, p. 163-176.

Kuntz, M. A., H. R. Covington, and L. J. Schorr (1992), An overview of basaltic volcanism of the eastern Snake River Plain, Idaho, in Regional Geology of Eastern Idaho and Western Wyoming, Link, P. K. Kuntz, M. A., and Platt, L. B. editors, Geological Society of America Memoir 179, 227-267.

McQuarrie, N., and D. W. Rodgers (1998), Subsidence of a volcanic basin by flexure and lower crustal flow: The eastern Snake River Plain, Idaho: Tectonics, v. 17, p. 203-220.

Nuclear Regulatory Commission (2001), Technical basis for revision of regulatory guidance on design ground motions: Hazard and risk-consistent ground motion spectra guidelines, NUREG/CR-6728, October.

Peng, X. and E. D. Humphreys (1998). Crustal velocity structure across the eastern Snake River Plain and the Yellowstone swell, Journal of Geophysical Research, v. 103, p. 7171-7186.

Pierce, K. L. and Morgan, L. A. (1992), The track of the Yellowstone hot spot: Volcanism, faulting, and uplift, in P.K. Link et al., editors, Regional Geology of Eastern Idaho and Western Wyoming, Geological Society of America Memoir 179, 1-54.

Purdy, G. M. (1982), Variability of seismic structure of Layer 2 near the EPR at 12 degrees north; Journal of Geophysical Research, v. 87, p. 8430-8416.

Redpath, B. (1997), Letter transmittal to R.P. Smith of downhole velocity measurements at boreholes LF3-11B and Site 14, June.

Reilinger, R. E., G. P. Citron, and L. D. Brown (1977), Recent vertical crustal movements from precise leveling data in southwest Montana, western Yellowstone National Park, and the Snake River Plain, Journal of Geophysical Research, v. 82, p. 5349-5359.

Rodgers, D. W., H. T. Ore, R. T. Bobo, N. McQuarrie, and N. Zentner (2002), Extension and subsidence of the eastern Snake River Plain, Idaho, in Bill Bonnichsen, C.M. White, and M. McCurry, eds., Tectonic and magmatic evolution of the Snake River Plain Volcanic Province, Idaho Geological Survey Bulletin 30, p. 121-155.

Sabetta, F. and A. Pugliese (1996), Estimation of response spectra and simulation of nonstationary earthquake ground motions, Bulletin of the Seismological Society of America, v. 86, p. 337-352.

Sadigh, K., C.-Y. Chang, J. A. Egan, F. Makdisi, and R. R. Youngs (1997), Attenuation relationships for shallow crustal earthquakes based on California strong motion data, Seismological Research Letters, v. 68, p. 180-189.

Schlumberger (1979), Borehole compensated sonic logs and compensated neutron-formation density logs of INEL\#1, Logs prepared for EG\&G Idaho, Inc., Idaho Falls, Idaho.

Scott, J. H., C. J. Zablocki, and G. H. Clayton (1979), Geophysical well-logging data from exploration well 2-2A, Idaho National Engineering Laboratory, Butte County, Idaho, U. S. Geological Survey Open-File Report 79-1460. 
Sparlin, M. A., L. W. Braile, and R. B. Smith (1982). Crustal Structure of the Eastern Snake River Plain Determined from Ray Trace Modeling of Seismic Refraction Data, Journal of Geophysical Research, v. 87, p. 2619-2633.

Spudich, P., J. B. Fletcher, M. Hellweg, J. Boatwright, C. Sullivan, W. B. Joyner, T. C. Hanks, D. M. Boore, A. McGarr, L. M. Baker, and A. G. Lindh (1997), SEA96- A new predictive relation for earthquake ground motions in extensional tectonic regimes, Seismological Research Letters, v. 68, p. 190-198.

Sutton, G. H., G. L. Maynard, and D. M. Hussong (1971), Widespread occurrence of a high-velocity basal layer in the Pacific crust found with repetitive sources and sonobuoys, Geophysical Monograph, v. 14, p. 193-209.

URS Greiner Woodward-Clyde Federal Services (1999), Final Report: Development of Design Basis Earthquake Parameters for TMI-2 Independent Spent Fuel Storage Installation at the INEEL, Bechtel BWXT Idaho, LLC., External Report INEEL/EXT-99-00619, November.

URS Greiner Woodward-Clyde Federal Services (2000), Recomputation of the Seismic Hazard at the Idaho National Engineering and Environmental Laboratory, Bechtel BWXT Idaho, LLC., External Report INEEL/EXT-99-00786, February.

Vera, E. E., and J. C. Mutter (1988), Crustal structure in the ROSE area of the East Pacific Rise; onedimensional travel time inversion of sonobuoys and expanded spread profiles, Journal of Geophysical Research, v. 93, p. 6635-6648.

Wilkins, R. H., G. J. Fryer, and J. Karsten (1991), Evolution of porosity and seismic structure of upper oceanic crust: importance of aspect ratios, Journal of Geophysical Research, v. 96, p. 17,98117,995 .

Woodward-Clyde Consultants (1990), Earthquake strong ground motion estimates for Idaho National Engineering Laboratory, Final Report Volume I: Summary; Volume II - Methology and Analyses; Volume III - Appendices, EG\&G Idaho Inc., Informal Report EGG-BG-9350, November.

Woodward-Clyde Consultants, Geomatrix Consultants, and Pacific Engineering and Analysis (1992), Earthquake ground motion evaluations for the proposed New Production Reactor at the Idaho National Engineering Laboratory, Volume I: Deterministic Evaluation and Volume II: Probabilistic Evaluation, EG\&G Idaho Inc., Informal Report EGG-GEO-10304, June.

Woodward-Clyde Federal Services, Geomatrix Consultants, and Pacific Engineering and Analysis (1996), Site-specific Seismic Hazard Analyses for the Idaho National Engineering Laboratory, Volume I Final Report and Volume 2 Appendix, Lockheed Idaho Technologies Company Informal Report, INEL-95/0536, May.

Youngs, R. R., Swan, III, F. H. and Power, M. S. (1988), Use of detailed geologic data in regional probabilistic seismic hazard analysis - an example from the Wasatch Front, Utah, in Earthquake Engineering and Soil Dynamics II: Recent Advances in Ground Motion Evaluation, American Society of Civil Engineering, ASCE Geotechnical Special Publication 20, p. 156-172. 


\section{Appendix A \\ Stochastic Point-Source Ground Motion Model}


(Intentionally Blank) 


\section{Appendix A \\ Stochastic Point-Source Ground Motion Model}

\section{A.1 Acceleration Spectral Density}

Based on the stochastic point-source model, the acceleration spectral density a( $f)$ for shear waves in the near-field is given by:

$$
\mathrm{a}(\mathrm{f})=\mathrm{C} \frac{f^{2}}{1+\left(f / f_{c}\right)^{2}} \frac{M_{O}}{R} \mathrm{P}(f) \mathrm{A}(f) e^{\frac{-\pi \mathrm{R} f}{\beta_{0} Q(f)}}
$$

where:

$$
\begin{aligned}
& \mathrm{M}_{\mathrm{O}}=\text { Seismic moment, which is related to moment magnitude }\left(\mathrm{M}_{\mathrm{w}}\right) \text { by the relation } \\
& \text { (Hanks and Kanamori 1979), } \log \mathrm{M}_{\mathrm{O}}=1.5 \mathrm{M}_{\mathrm{w}}+16.1 \\
& \mathrm{R}=\text { Distance to the equivalent point source. } \\
& \beta_{O} \quad=\quad \text { Shear-wave velocity at the source. } \\
& \mathrm{Q}(f)=\text { Frequency-dependent quality factor model where } \mathrm{Q}(f)=\mathrm{Q}_{o} f^{\eta} \text {; } \mathrm{Q}_{o} \text { and } \eta \text { are } \\
& \text { model parameters. } \\
& f_{\mathrm{c}}=\text { Source corner frequency (Brune 1970; 1971), which is related to the stress drop } \Delta \sigma \\
& \text { and } \mathrm{M}_{\mathrm{O}} \text { through the relation: } f_{\mathrm{c}}=\beta_{O}\left(\Delta \sigma / 8.44 \mathrm{M}_{\mathrm{O}}\right)^{1 / 3} \\
& \mathrm{C}=\left(1 / \rho_{0} \beta_{O}{ }^{3}\right) \times(2) \times(0.55) \times(1 \sqrt{ } 2) \times \pi \text {; A constant that contains source region density } \\
& \rho_{0} \text { and shear-wave velocity terms, accounts for the free-surface effect (factor of } 2 \text { ), } \\
& \text { the source radiation pattern average over a sphere (0.55) (Boore 1986), and the } \\
& \text { partition of energy into two horizontal components }(1 \sqrt{ } 2) \text {. }
\end{aligned}
$$

\section{A.2 Near-surface Crustal Damping}

The high-frequency truncation filter $\mathrm{P}(f)$ models the observation that acceleration spectral density appears to fall off rapidly beyond some region-dependent maximum frequency. The spectral fall-off may be attributed to near-site attenuation or source processes or both. For the INL PSHA, P $(f)$ is represented by the attenuation model of Anderson and Hough (1984):

$$
\mathrm{e}^{-\pi \kappa(\mathrm{r}) f}
$$


where $\kappa(r)$ is a site- and distance-dependent parameter that represents the effect of intrinsic attenuation on the seismic waves as they propagate through the crust from source to receiver. At zero epicentral distance, $\kappa$ is given by:

$$
\kappa(0)=\frac{H}{\bar{\beta}_{R} \bar{Q}_{S}}
$$

where $\beta_{R}$ and $\mathrm{Q}_{S}$ are averaged over a depth of $H$ beneath the receiver site. The value of $\kappa(0)$ is attributed to attenuation in the very shallow crust to a depth of about $3 \mathrm{~km}$ (Woodward-Clyde Federal Services et al. 1996).

\section{A.3 Attenuation Functional Form}

For each facility area, nine stochastic attenuation relationships for peak ground acceleration (PGA) and peak spectral accelerations were obtained by fitting the simulated data with the functional form:

$$
\begin{aligned}
& \begin{array}{l}
\mathrm{R}^{\prime} \leq 90 \mathrm{~km} \\
\ln (\mathrm{Y})=\mathrm{C}_{1}+\mathrm{C}_{2}\left(\mathrm{M}_{\mathrm{w}}-6\right)^{2}+\mathrm{C}_{3}\left(\mathrm{M}_{\mathrm{w}}-6\right)^{2}+\mathrm{C}_{4} \ln \left(\mathrm{R}^{\prime}\right)+\mathrm{C}_{6} \mathrm{R}^{\prime} \\
\mathrm{R}^{\prime}>90 \mathrm{~km} \\
\ln (\mathrm{Y})=\mathrm{C}_{1}+\mathrm{C}_{2}\left(\mathrm{M}_{\mathrm{w}}-6\right)^{2}+\mathrm{C}_{3}\left(\mathrm{M}_{\mathrm{w}}-6\right)^{2}+\mathrm{C}_{4} \ln (90)+\mathrm{C}_{5} \ln \left(\mathrm{R}^{\prime} / 90\right)+\mathrm{C}_{6} \mathrm{R}^{\prime} \\
\mathrm{R}^{\prime}=\sqrt{R^{2}+\left(C_{7}+C_{8} M_{w}\right)^{2}}
\end{array}
\end{aligned}
$$

where $\mathrm{Y}$ is the peak ground motion parameter, $\mathrm{R}$ is the shortest distance to the surface projection of rupture (similar to Boore et al. [1997] empirical attenuation model), and $\mathrm{C}_{1}$ through $\mathrm{C}_{8}$ are parameters to fit the data. The change in distance attenuation coefficient at $90 \mathrm{~km}$ matches the geometric spreading model used in the stochastic estimates (URS Greiner Woodward Clyde Federal Services et al. 1999; 2000). 


\section{Appendix B}

Seismic Wave and Density Measurements 
(Intentionally Blank) 


\section{Appendix B}

\section{Seismic Wave and Density Measurements}

\section{Sediment and Rock Measurements at INL}

This appendix provides background on the available seismic velocity and density measurements of the basalts, rhyolites, and sedimentary interbeds at INL. These data were used to develop the velocityand density- depth relationships discussed in Section 4.2.1.2. Seismic velocities and densities have been measured for basalt, rhyolite, and sedimentary interbeds in four deep drill holes at INL. Figure B-1 shows a summary of the seismic velocity and density measurements for drill holes INEL-1, WO-2, 2-2A, and ANL-1. Other measurements are shown in Figures 5 through 8 in the report text.

Seismic velocities for basalts at INL have been measured at the near surface and within deep drill holes. Seismic velocities at the near surface $(<100 \mathrm{~m})$ have been obtained using down-hole (surface to borehole) logging, cross-hole logging, and surface seismic refraction surveys. Most of the measurements were obtained as part of geotechnical investigations for facilities. Near-surface basalt P-wave velocities range from 1.0 to $3.0 \mathrm{~km} / \mathrm{s}$ and S-wave velocities range from 0.5 to $1.5 \mathrm{~km} / \mathrm{s}$ (Figure 5).

Velocity logs in INEL-1 are standard Schlumberger sonic logs (Schlumberger 1979). In the basalts they show a broad range in velocity that reflect the variations of high velocities in the interior of a lava flow to low velocities in the lava flow contact zones. Similar high-to-low velocity variations within the basalt were also observed in the sonic logs of drill hole 2-2A (Scott et al. 1979) and suspension logs in drill hole ANL-1 (Agbabian Associates Inc. 1995). Overall, seismic velocities of basalts increase rapidly with depth. At depths of $200 \mathrm{~m}$, P-wave velocities range from 3.0 to $5.0 \mathrm{~km} / \mathrm{s}$ and S-wave velocities range from 1.5 to $2.5 \mathrm{~km} / \mathrm{s}$. Increases in velocities beyond the $200 \mathrm{~m}$ depth range is more gradual, with P-wave velocities that range from 4.8 to $6.0 \mathrm{~km} / \mathrm{s}$ from 500 to $600 \mathrm{~m}$ depth. No S-wave velocities are available below a depth of about $375 \mathrm{~m}$, and at that depth the velocities range from 1.5 to $2.5 \mathrm{~km} / \mathrm{s}$.

The P-wave velocities of the rhyolites are much more coherent (Figure B-1). Velocities of rhyolitic volcanic rocks beneath the basalts were measured in the sonic logs of drill hole INEL-1 (Schlumberger 1979). The sonic logs indicate rhyolite $P$-wave velocities range from about 3.5 to $4.0 \mathrm{~km} / \mathrm{s}$ at about a depth of $800 \mathrm{~m}$ then gradually increase to about $5.5 \mathrm{~km} / \mathrm{s}$ at a depth of $3000 \mathrm{~m}$.

P-wave and S-wave velocities have been measured for surface sediments above basalt bedrock at facility areas RTC, MFC, INTEC, NRF and Central Facilities Area (CFA), the proposed New Production Reactor (NPR) site, and drill hole Site-14. Seismic velocities were obtained in Site-14 (Redpath 1997) after the velocity-depth relationships were developed. The P-wave velocities of the sediments in Site 14 are generally consistent with the sedimentary interbed P-wave velocity-depth relationship, whereas the Swave velocities are lower than the $S$-wave velocity-depth relationship at depths from 30 to $100 \mathrm{~m}$ (Figure 8). The sediments in Site-14 are above the basalt bedrock and may or may not be representative of the sedimentary intebeds within the basalt for the following reasons:

- $\quad$ The sediments at Site-14 are dry and above the water table, whereas most sedimentary interbeds are below the water table and saturated. Saturation of the eolian components of the sediment can result in significant compaction and hence an increase in the S-wave velocities.

- The sediments at Site-14 contain a high component of "lunette"-type dunes. These are windblown deposits of sand-sized agglomerates of clay and silt particles, and such deposits are more porous and less dense that typical alluvial or eolian sediments at INL. 
Measured velocities of sedimentary interbeds are limited in drill holes due to the instability of the sediments and the need for casing or cement in thick interbed zones. The sediment interbeds are unconsolidated to poorly consolidated and tend to cave into drill holes. P-wave velocities of sedimentary interbeds were measured in the sonic logs of two deep drill holes INEL-1 and 2-2A (Schlumberger 1979; Scott et al. 1979). In INEL-1 the P-wave measurements are within the thick tuffaceous sediment layer at the base of the basalts (Figure B-1). The P-wave velocities of the tuffaceous sediments may not be representative of velocities for sedimentary interbeds throughout the basalt section because of the high volcanic component. Also, the measured P-wave velocities in the sonic logs of drill hole 2-2A may be biased towards high values because the sedimentary interbeds are so thin and the sonic signals may have traveled partly within the higher-velocity basalt layers above or below the sedimentary interbed.

Density measurements of basalts and rhyolites consist of in-situ and laboratory measurements of rocks at the surface, density logs in drill holes 2-2A, INEL-1, and WO-2, and laboratory measurement of a core sample from drill hole 2-2A. The density log in WO-2 has a depth range from 550 to $1300 \mathrm{~m}$, but steel casing and drill rods were necessary to keep the hole open for logging (Filipkowski et al. 1991). Even though the density log of WO-2 was obtained in steel-cased conditions, the densities are similar to those obtained in open-hole conditions for drill holes 2-2A and INEL-1 (Schlumberger 1979; Scott et al. 1979). For the density logs, the basalt densities range from 2.5 to $3.0 \mathrm{gm} / \mathrm{cm}^{3}$ and the rhyolite densities range from 2.4 to $2.5 \mathrm{gm} / \mathrm{cm}^{3}$. There is a slight increase of the densities with depth.

Densities for sediments consist of in-situ measurements in pits at the surface, density logs in drill holes 2-2A and INEL-1 (Schlumberger 1979; Scott et al. 1979), and laboratory measurements of samples from drill hole 2-2A (DeVan and Martin 1989). The sediment densities are inconsistent or have unusual characteristics that contribute to uncertainty about the density value. The laboratory measurements for sediment samples of drill hole 2-2A vary widely and are significantly higher than the densities measured the drill logs from similar depth ranges. The density of the tuffaceous sediment layer at the base of the basalt section ( $700 \mathrm{~m}$ depth) in drill hole INEL-1 may not be representative of the densities of sedimentary interbeds.

\section{Comparison of INL Basalt Velocities to Ocean Floor and Columbia Plateau Basalt Velocities}

Figure B-2 shows INL P-wave and S-wave velocity-depth profiles for basalt based on existing data and compared to seismic velocity data from basalts in other parts of the world. Most published velocity data for basalts come from the ocean floor. Except for very low velocities near the surface, the INL basalt velocity profile is similar to that of ocean floor basalts (Figure B-2). The low near-surface velocities for INL basalts compared to ocean floor basalts is due to several factors, including unsaturated conditions, presence of numerous open fractures, infiltration of silty sediments into fractures, rubbly layers between lava flows, and relatively thin lava flows. At depths of 0.5 to $1 \mathrm{~km}$, INL basalts have slightly lower velocities than those of the Columbia Plateau basalts (Figure B-2), a situation that is also attributed to the thin flows, numerous rubble zones, infiltrating sediments, and abundant fractures of basalts in the ESRP. 


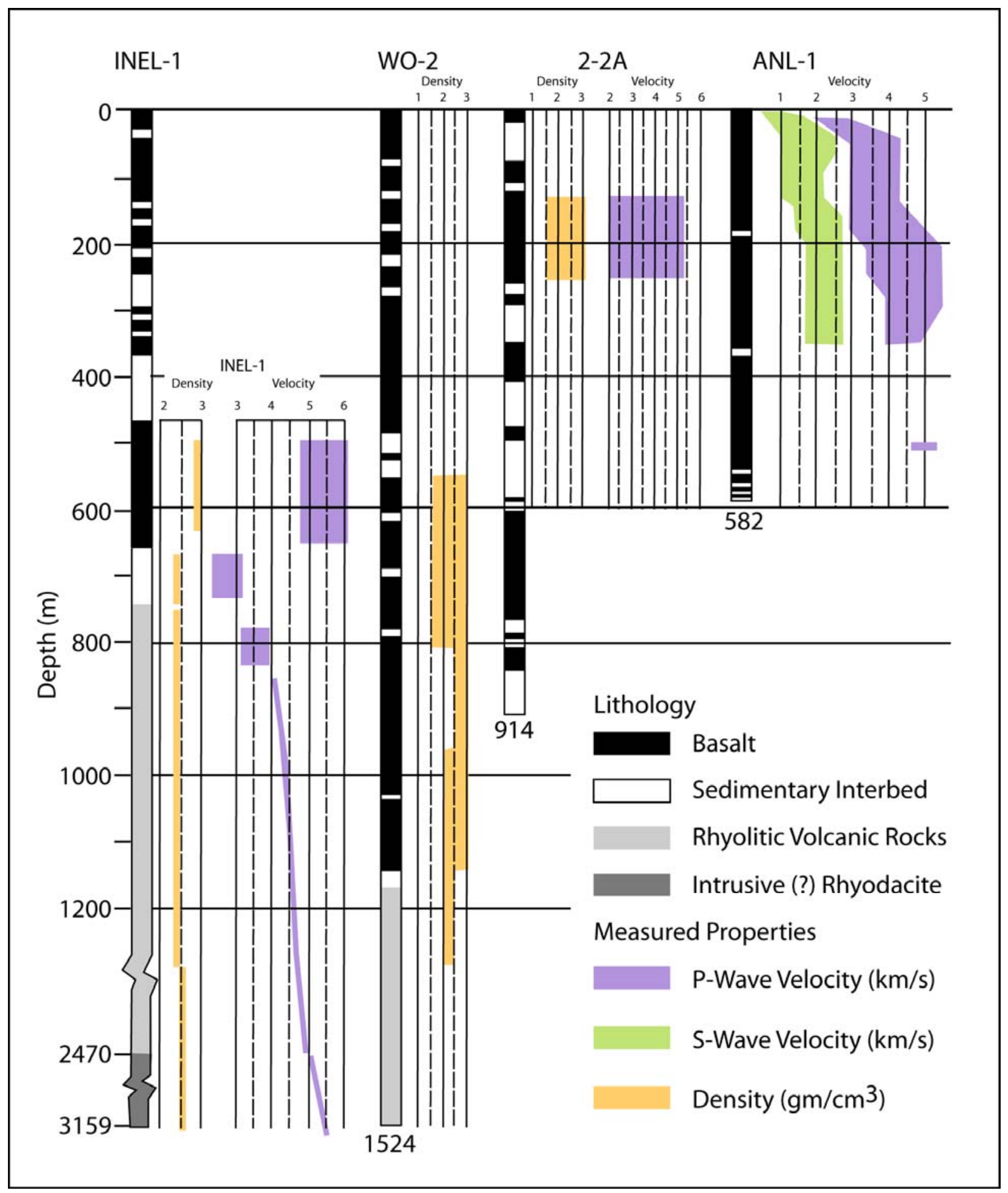

Figure B-1. Summary of the lithology, seismic velocities, and densities of drill holes INEL-1, WO-2, 2$2 \mathrm{~A}$, and ANL-1. 


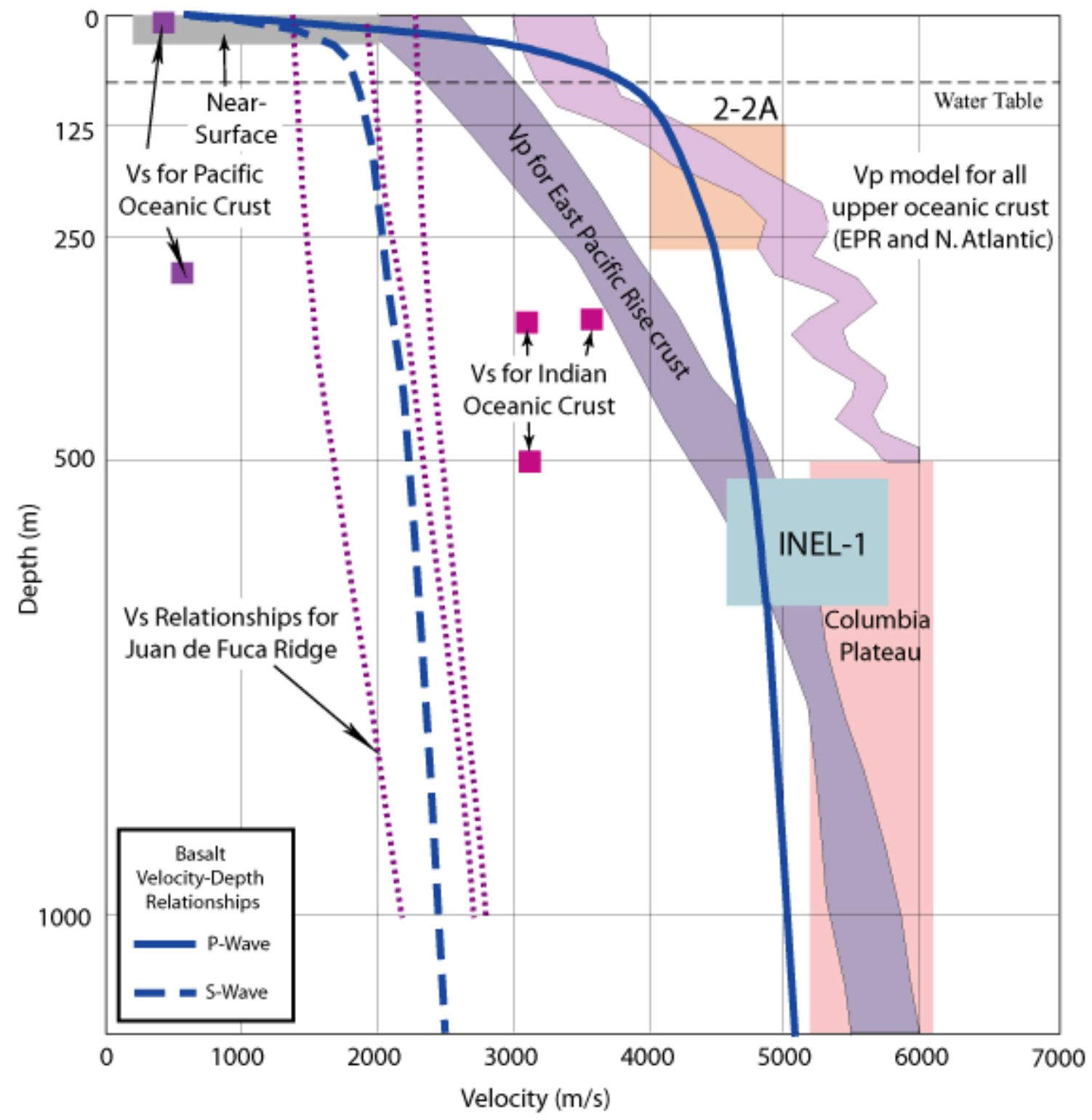

Figure B-2. Basalt velocity-depth relationships and ranges of measured basalt velocities at INL for: near-surface P-wave velocity measurements (gray box); drill hole 2-2A (orange box); and drill hole INEL-1 (blue box). For comparison, basalt velocities are shown for: Columbia Plateau (Jarchow and Catchings 1994); Pacific oceanic crust (Sutton et al. 1971); East Pacific Rise crust (Bratt and Purdy 1982); and Indian oceanic crust (Francis and Shor 1966); and velocity-depth relationships for: all upper oceanic crust of the East Pacific Rise (EPR) and North Atlantic (Vera and Mutter 1988; Wilkins et al. 1991); and the Juan de Fuca Ridge (Crawford et al. 1993). 


\section{Appendix C}

\section{Smoothed Shear-wave Velocity Profiles}


(Intentionally Blank) 


\section{Appendix C}

\section{Smoothed Shear-wave Velocity Profiles}

Site-specific S-wave velocity profiles were developed for each location used in the INL PSHA to estimate horizontal ground motion levels for rock conditions. Section 4.2 discusses how the site-specific S-wave profiles shown in Figures C-1 through C-6 were developed and smoothed. S-wave velocity values for the site-specific profiles can be obtained from Woodward Clyde Federal Services et al. (1996;

Appendix E). Three INL facility names are different from those used in the 1996 report: the Advanced Test Reactor (ATR) is now identified as the Reactor Technology Complex (RTC) shown in Figure C-1; Argonne National Laboratory West (ANL) is now identified as the Materials and Fuels Complex (MFC) shown in Figure C-6; and the Idaho Chemical Processing Plant (CPP) in now identified as the Idaho Nuclear Engineering and Technology Center (INTEC) shown in Figure 9 of report text. 


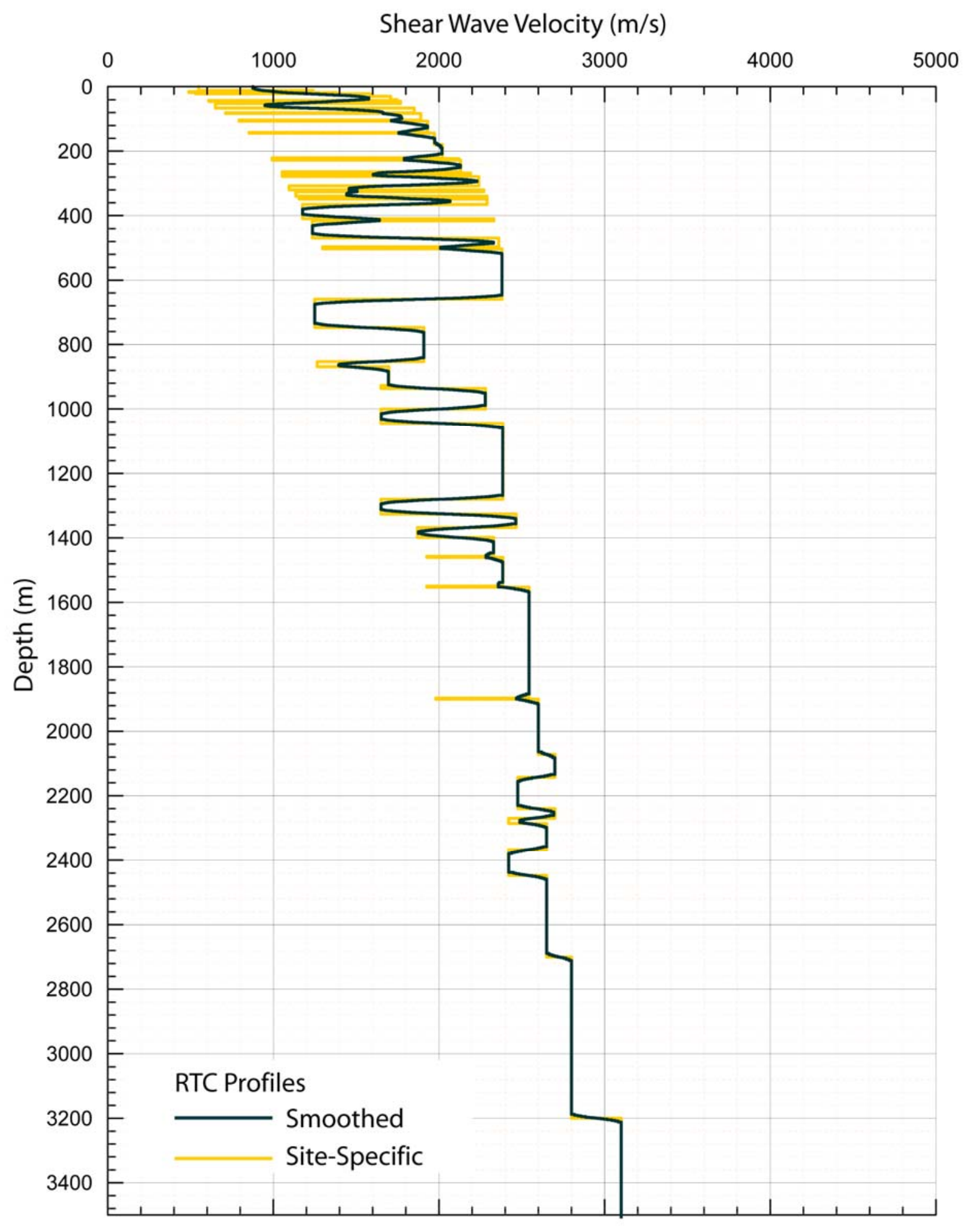

Figure C-1. Site-specific and smoothed shear-wave velocity profiles developed for RTC (WoodwardClyde Federal Services et al. 1996; referred to as ATR). 


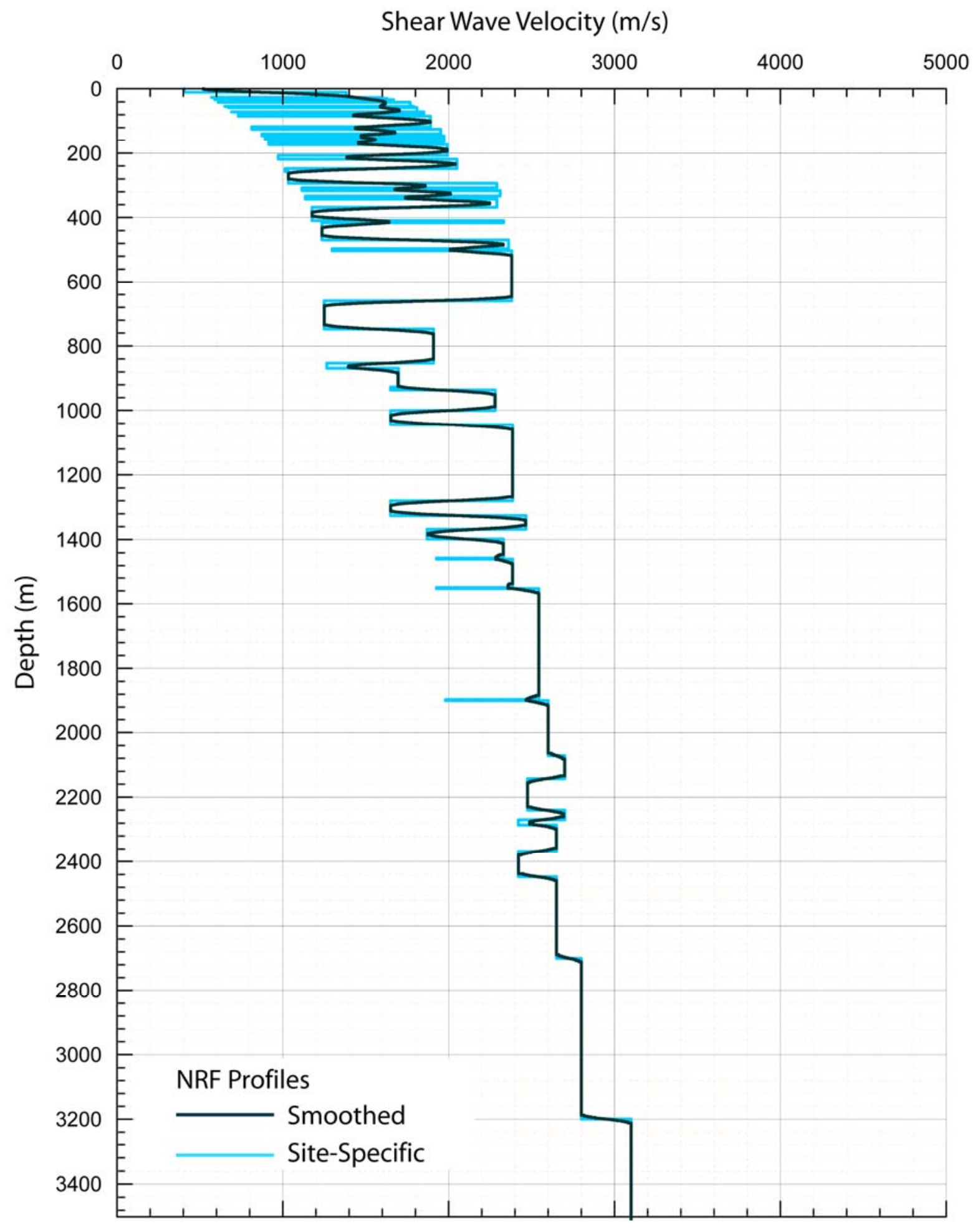

Figure C-2. Site-specific and smoothed shear-wave velocity profiles developed for NRF (WoodwardClyde Federal Services et al. 1996). 


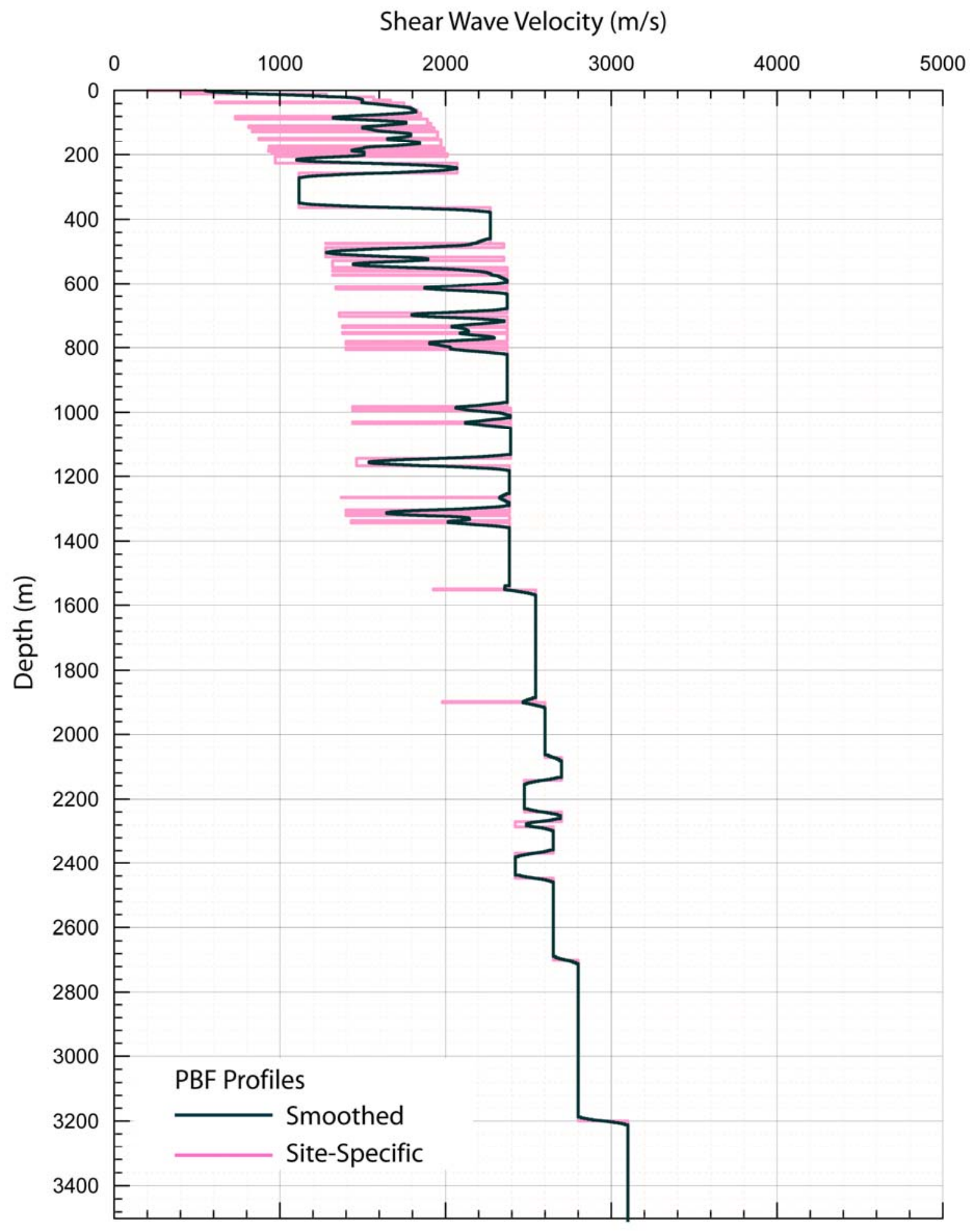

Figure C-3. Site-specific and smoothed shear-wave velocity profiles developed for PBF (WoodwardClyde Federal Services et al. 1996). 


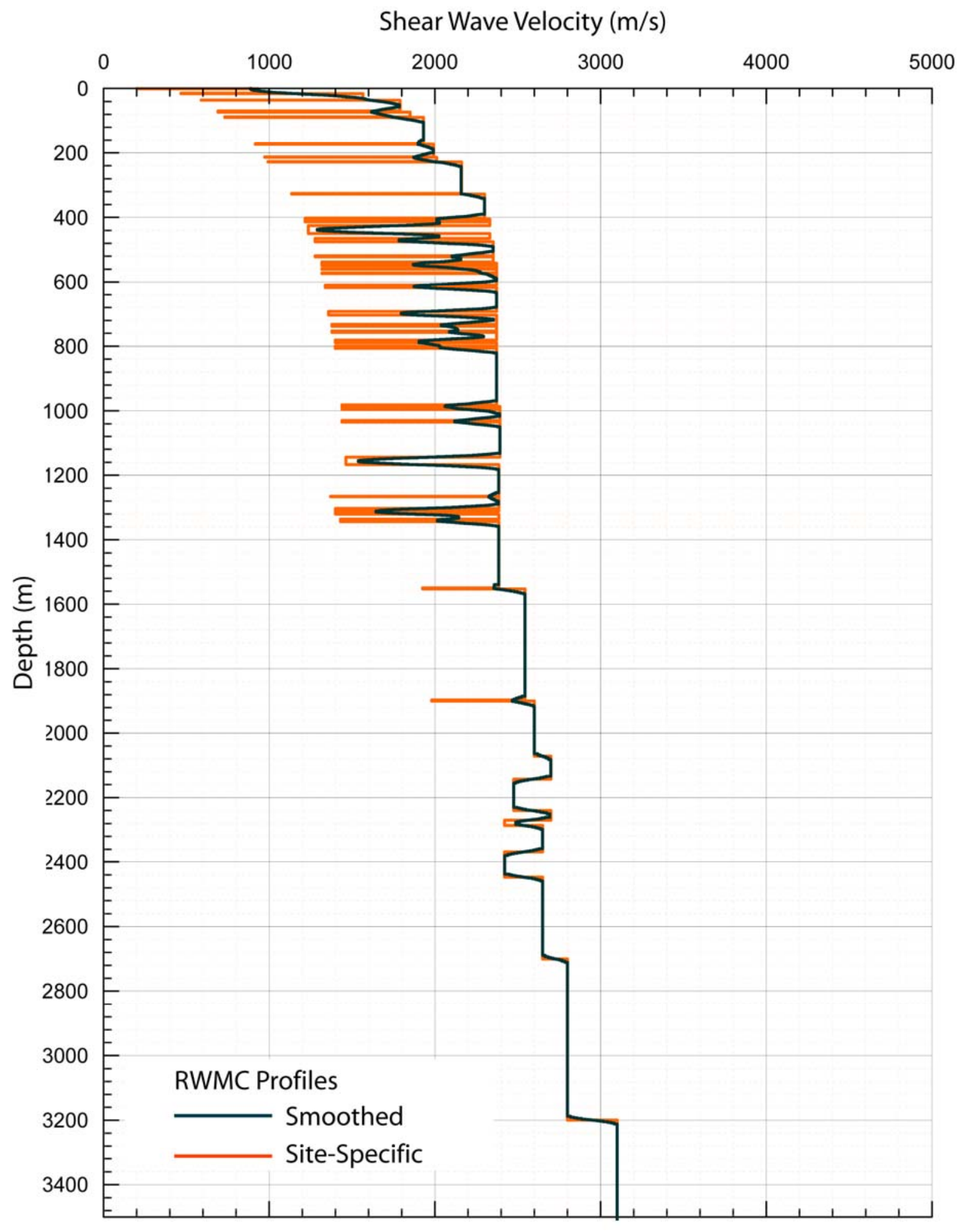

Figure C-4. Site-specific and smoothed shear-wave velocity profiles developed for RWMC (WoodwardClyde Federal Services et al. 1996). 


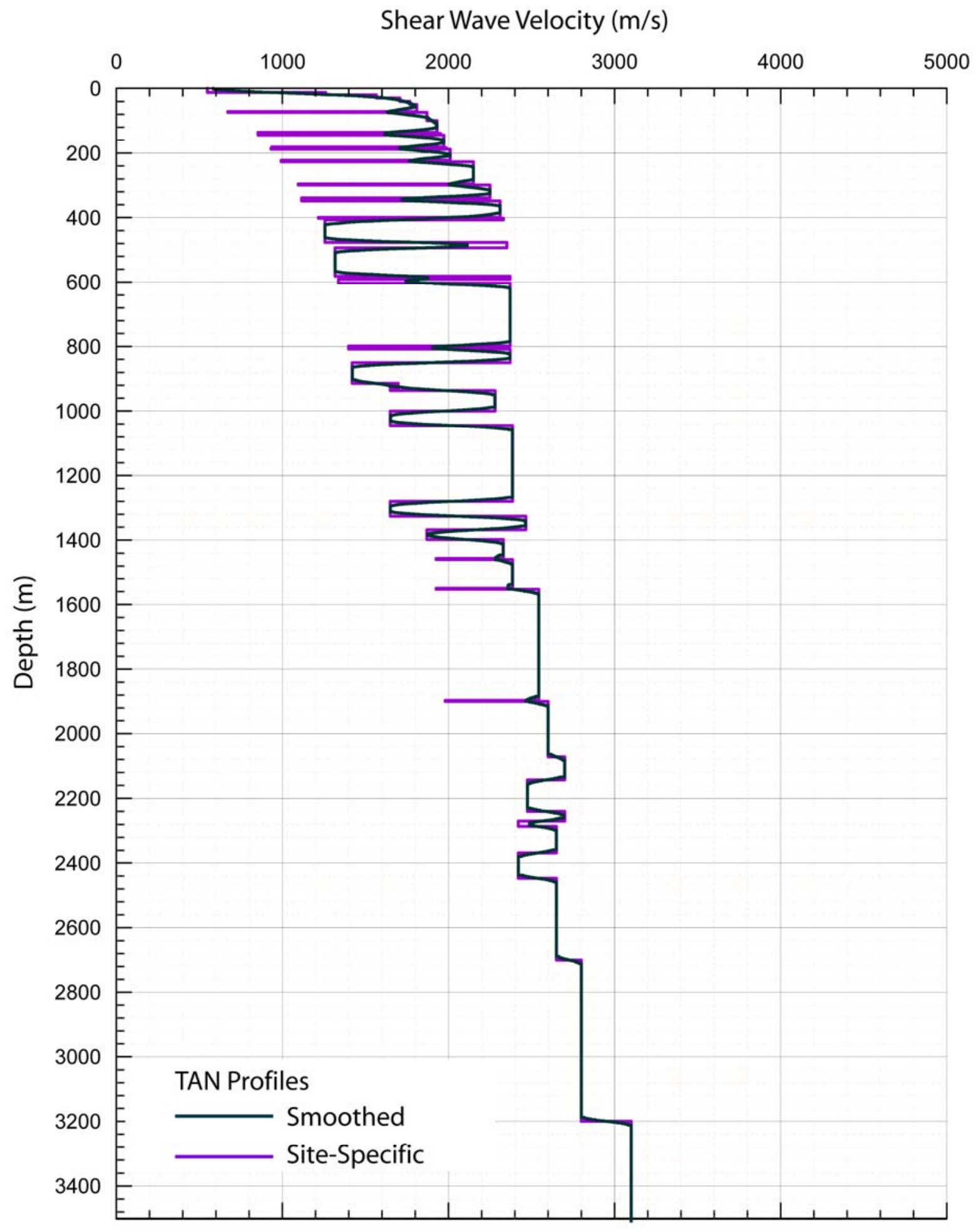

Figure C-5. Site-specific and smoothed shear-wave velocity profiles developed for TAN (WoodwardClyde Federal Services et al. 1996). 


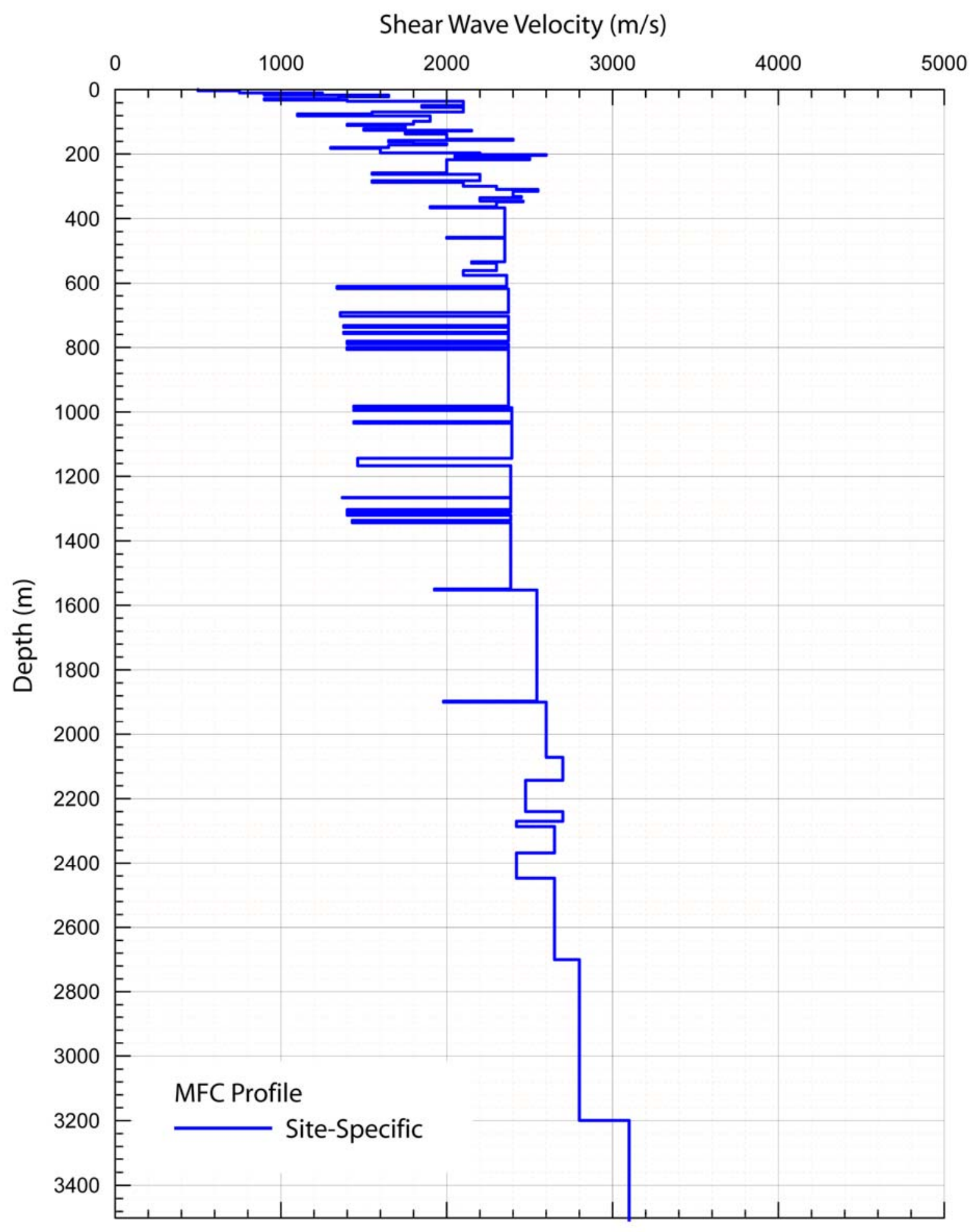

Figure C-6. Site-specific shear-wave velocity profiles developed for MFC (Woodward-Clyde Federal Services et al. 1996; referred to as ANL). 


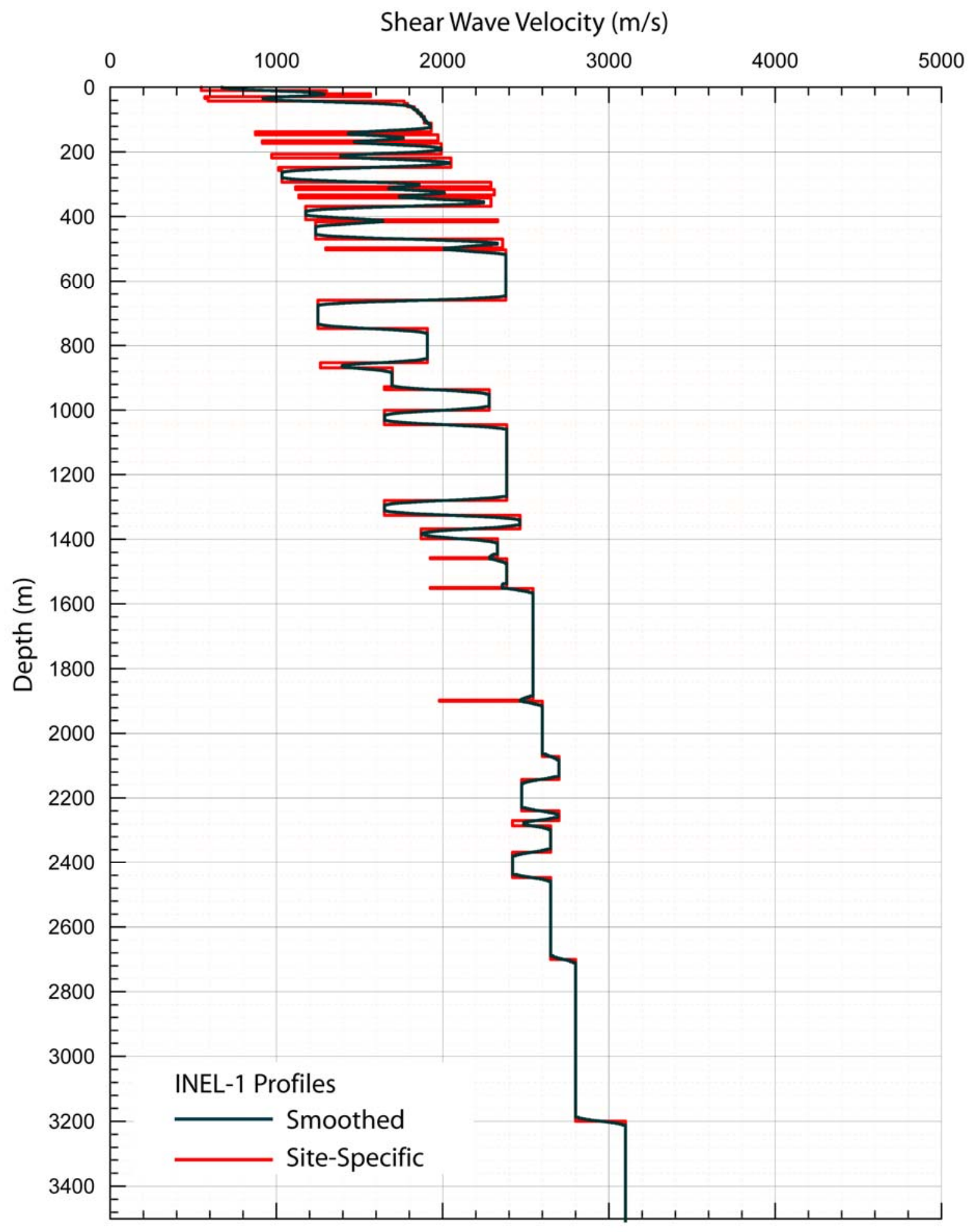

Figure C-7. Site-specific and smoothed shear-wave velocity profiles developed for drill hole INEL-1 (Woodward-Clyde Federal Services et al. 1996). 